\title{
Guidelines and Standard Procedures for High-Frequency Groundwater-Quality Monitoring Stations-Design, Operation, and Record Computation
}

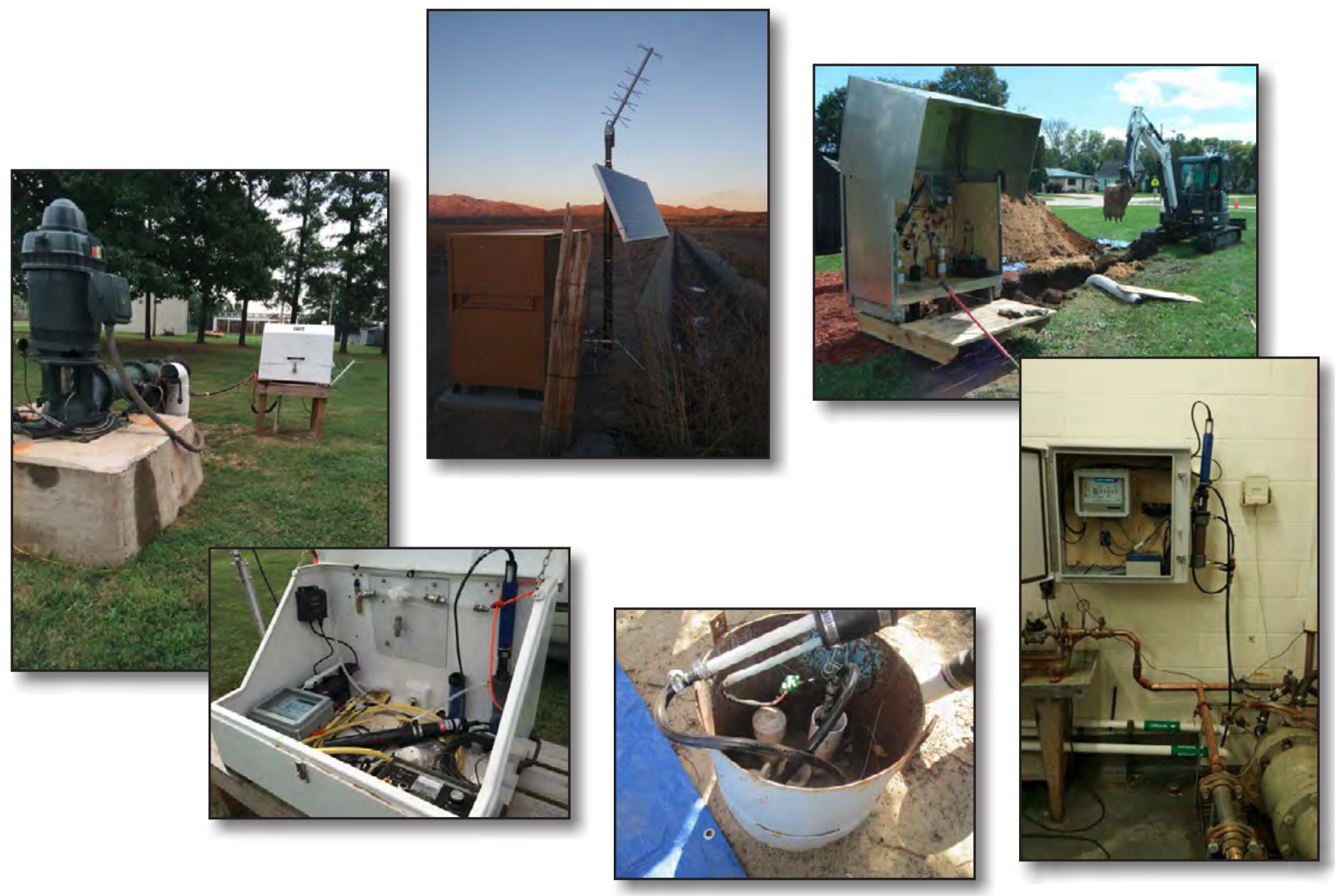

Techniques and Methods 1-D7 


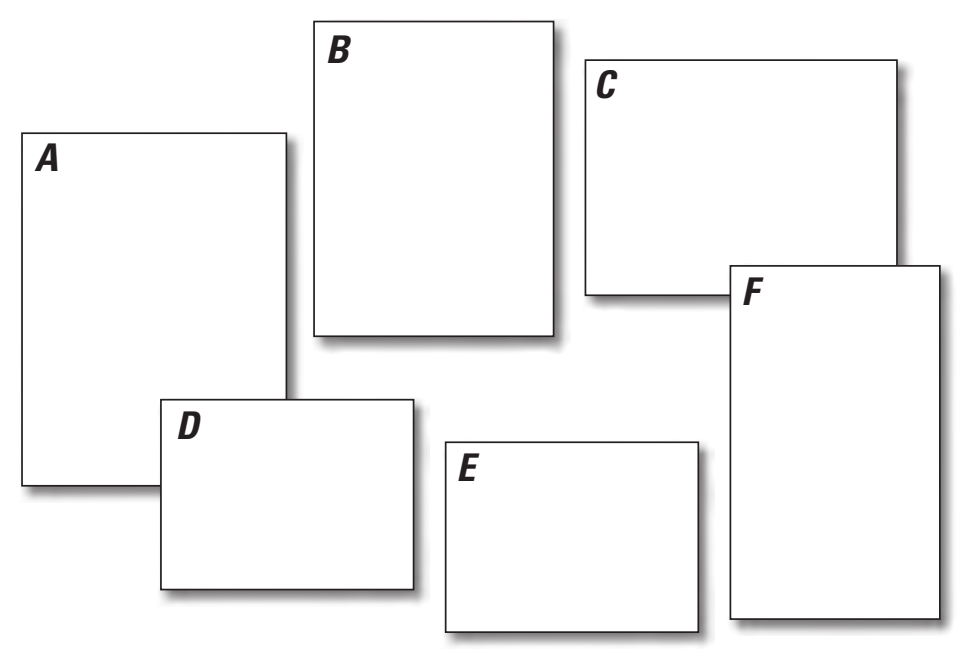

\section{Front cover.}

A: High-capacity supply well and instrument enclosure at a high-frequency groundwater-quality monitoring station, Memphis, Tennessee. Photograph taken by Randy Thomas, U.S. Geological Survey.

B: Instrument enclosure, transmission equipment, and solar array at a high-frequency groundwater-quality monitoring well station, Rincon Valley, New Mexico. Photograph taken by Jay Cederberg, U.S. Geological Survey.

c: Construction of a high-frequency groundwater-quality monitoring station, near Spring Green, Wisconsin. Photograph taken by Jason Smith, U.S. Geological Survey.

D: High-frequency groundwater-quality monitoring equipment deployed at a monitoring well, Memphis, Tennessee. Photograph taken by Randy Thomas, U.S. Geological Survey.

E: Monitoring well, with cover open, at a high-frequency groundwater-quality monitoring station, Fresno, California. Photograph taken by Timothy Mathany, U.S. Geological Survey.

F: High-frequency groundwater-quality monitoring equipment deployed at a high-capacity supply well, Seabrook, New Hampshire. Photograph taken by James Degnan, U.S. Geological Survey.

\section{Back cover.}

High-capacity supply well and instrument enclosure at a high-frequency groundwater-quality monitoring station, San Antonio, Texas. Photograph taken by Jennifer Wilson, U.S. Geological Survey. 


\section{Guidelines and Standard Procedures for High-Frequency Groundwater-Quality Monitoring Stations-Design, Operation, and Record Computation}

By Timothy M. Mathany, John Franco Saraceno, and Justin T. Kulongoski

Techniques and Methods 1-D7 


\title{
U.S. Department of the Interior \\ DAVID BERNHARDT, Acting Secretary
}

\author{
U.S. Geological Survey \\ James F. Reilly II, Director
}

U.S. Geological Survey, Reston, Virginia: 2019

For more information on the USGS - the Federal source for science about the Earth, its natural and living resources, natural hazards, and the environment-visit http://www.usgs.gov or call 1-888-ASK-USGS.

For an overview of USGS information products, including maps, imagery, and publications,

visit http://store.usgs.gov.

Any use of trade, firm, or product names is for descriptive purposes only and does not imply endorsement by the U.S. Government.

Although this information product, for the most part, is in the public domain, it also may contain copyrighted materials as noted in the text. Permission to reproduce copyrighted items must be secured from the copyright owner.

Suggested citation:

Mathany, T.M., Saraceno, J.F., and Kulongoski, J.T., 2019, Guidelines and standard procedures for high-frequency groundwater-quality monitoring stations - Design, operation, and record computation: U.S. Geological Survey Techniques and Methods 1-D7, 54 p., https://doi.org/10.3133/tm1D7. 


\section{Acknowledgments}

The authors thank various cities, townships, and public entities for allowing us access to their high-capacity and monitoring well sites. We are also grateful to many domestic well owners for allowing the U.S. Geological Survey to monitor water-quality from their wells. 


\section{Contents}

Abstract

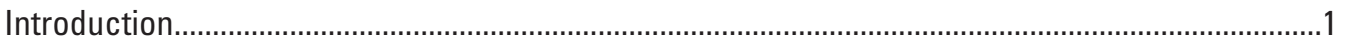

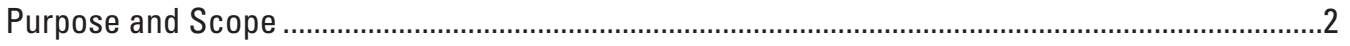

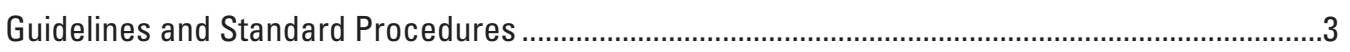

High-Frequency Groundwater-Quality Monitoring Station Selection.......................................

High-Frequency Groundwater-Quality Monitoring Station Design ...........................................

Station Design at Actively Pumped Wells .......................................................................

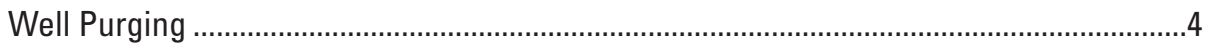

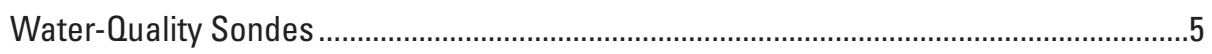

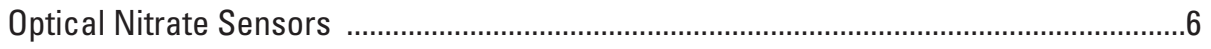

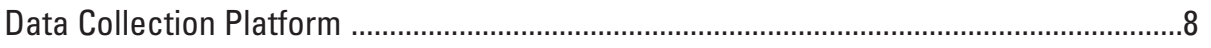

High-Capacity Supply Well Installations..................................................................

Domestic Supply Well Installations ..........................................................................

Monitoring Well Installations...................................................................................10

Actively Pumped Monitoring Well Installations …………......................................10

Submersible Pumps .........................................................................................10

Instrumentation Location ............................................................................11

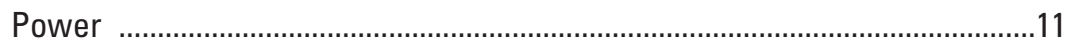

Passive Monitoring Well Installations..................................................................12

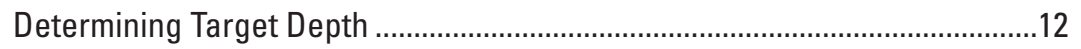

Hanging and Securing Sondes ..................................................................14

Transmitting Passive Groundwater-Quality Data .............................................14

High-Frequency Groundwater-Quality Monitoring Station Maintenance ..............................14

Deployed High-Frequency Groundwater-Quality Sonde Maintenance..................................15

Standard Maintenance Procedure for Deployed High-Frequency Groundwater-

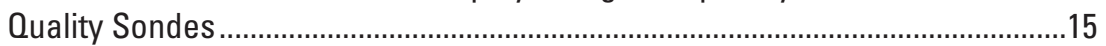

U.S. Geological Survey High-Frequency Groundwater-Quality Field Form.............16

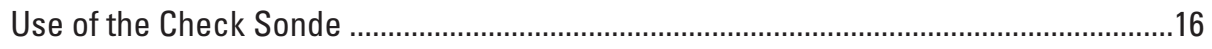

Sonde Readings During the Standard Maintenance Procedure .......................................16

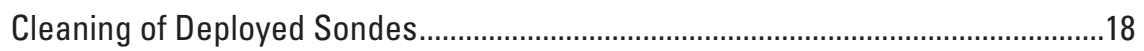

Water Temperature and Specific Conductance Sensor Cleaning ..................19

$\mathrm{pH}$ Electrode Cleaning .......................................................................... 19

Optical Dissolved Oxygen Sensor Cleaning ....................................................19

Optical Nitrate Sensor Cleaning......................................................................19

Calibration of Deployed and Check Sondes .........................................................19

Specific Conductance Sensor Calibration ....................................................20

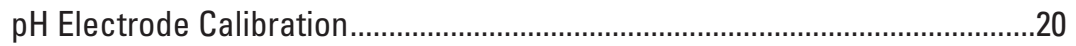

Optical Dissolved Oxygen Sensor Calibration ..............................................20

Water Temperature Sensor Calibration ...........................................................21

Optical Nitrate Sensor Calibration ................................................................

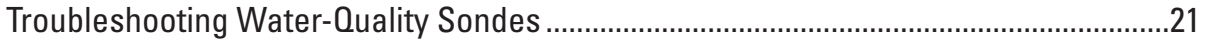

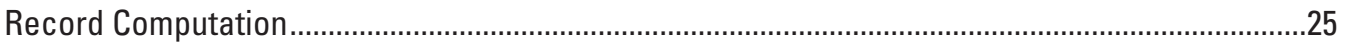




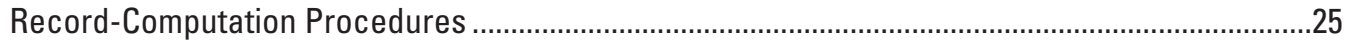

Reporting Units and Parameter and Method Codes................................................................25

Setting Up a New High-Frequency Groundwater-Quality Monitoring Station in the NWIS-Time Series Database ................................................................................25

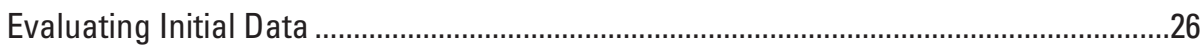

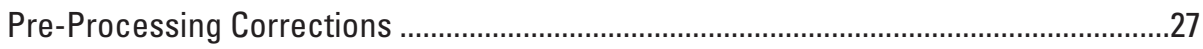

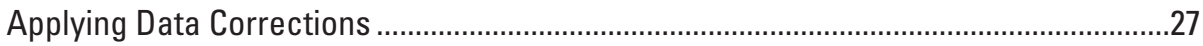

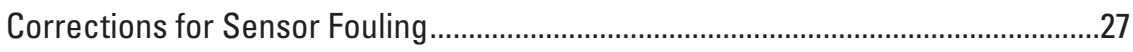

Corrections for Calibration Drift Error ....................................................................28

Sensor Recalibration and Data-Correction Thresholds ........................................28

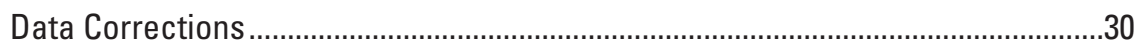

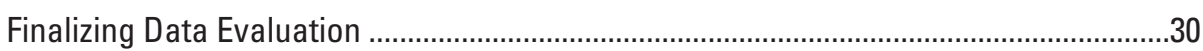

Maximum Allowable Limits for Reporting High-Frequency Groundwater-

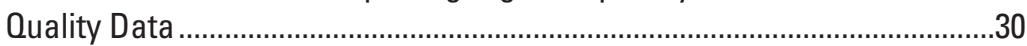

Finalizing the Data in the NWIS-TS Database ........................................................30

Finalizing Record and Documentation ............................................................................31

Components of the Final Records Review ..................................................................31

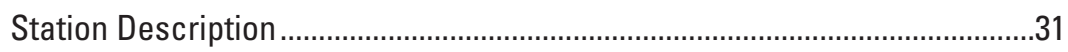

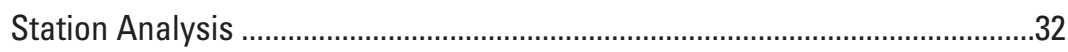

Standard Maintenance Procedure Results........................................................32

Plots of the Raw and Corrected Instantaneous Values....................................32

USGS NWIS Time-Series Data Report ..............................................................32

Approving of Groundwater-Quality Records ............................................................32

Auditing of Groundwater-Quality Records ............................................................32

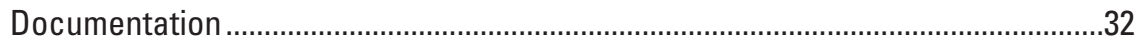

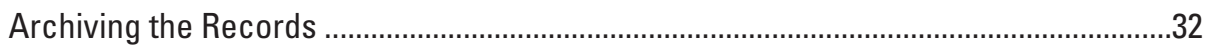

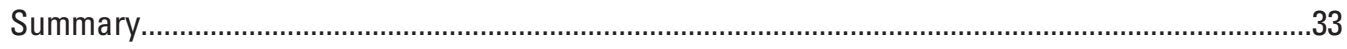

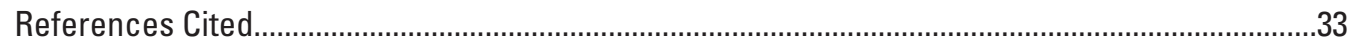

Appendix 1. Water-Quality Sonde Characterization .........................................................................37

Water-Quality Sonde Characterization Background ..............................................................37

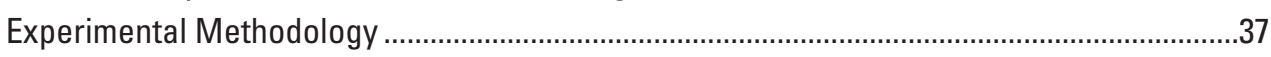

Electrical Conductivity Sensor Precision ................................................................................37

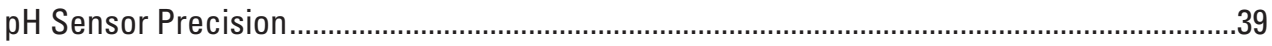

Long-Term Field Precision Analysis...............................................................................................41

Results of the Water-Quality Sonde Characterization...............................................................41

References Cited..................................................................................................................... 42

Appendix 2. U.S. Geological Survey High-Frequency Groundwater-Quality Field Form................43

Appendix 3. Example of a Station Description for a High-Frequency GroundwaterQuality Station.

Appendix 4. Example of a Station Analysis for a High-Frequency Groundwater-Quality Station ..48 Appendix 5. Example of a High-Frequency Groundwater-Quality Record Analyst Checklist.........50

Appendix 6. Example of a High-Frequency Groundwater-Quality Record Approver Checklist......52 


\section{Figures}

1. Generalized diagram showing example of a high-frequency groundwater-quality monitoring system for a single well station.

2. Generalized diagram showing example of a high-frequency groundwater-quality monitoring system for a multiple well station ....

3. Photograph showing pump operation magnetic deflectometer installed at USGS well 364200119420001, Fresno, California

4. Photograph showing optical nitrate sensor configuration at multiple well station USGS 364200119420001, 364200119420002, and 364200119420003, Fresno, California.......7

5. Photograph showing instrumentation shelter and equipment configuration at multiple-monitoring well station USGS 443320089212303 and 443320089212304 , near Spring Green, Wisconsin

6. Photograph from 2013 showing original instrumentation configuration at highcapacity supply well station USGS 364200119420001, Fresno, California ...8

7. Photograph showing instrumentation configuration at domestic well station USGS 454919119184701, Hermiston, Oregon ....

8. Photograph showing wellhead at monitoring well station USGS 364200119420003 , Fresno, California......

9. Photograph showing instrumentation shelter and equipment configuration at multiple well station USGS 364200119420001, 364200119420002, and 364200119420003, Fresno, California

10. Photograph showing wellhead, instrumentation shelter, and equipment configuration at monitoring well station USGS 323733107011002, Rincon Valley, New Mexico

11. Photograph showing quick-release couplings of the tubing and the electrical wiring at the wellhead of monitoring well station USGS 364200119420003 , Fresno, California

12. Graph showing raw and corrected $\mathrm{pH}$ time-series data and data from end of period site visit at USGS station 364200119420001, August and September 2017

13. Diagram showing suggested specialized setup for using representative groundwater during site-visit performance checks of the deployed sonde

14. Graph showing raw and corrected specific conductivity time-series data and data from end of period site visit at USGS station 364200119420003, February and March 2018

1-1. Diagram showing laboratory experiment setup ..............................................................

1-2. Photograph showing laboratory experiment setup .........................................................38

1-3. Graph showing specific conductance experiment time-series data ...............................39

1-4. Graph showing the de-trended specific conductance experiment time-series data.....40 


\section{Tables}

1. Gallons of water per foot of well casing.....

2. Well and groundwater pump information for the nine high-frequency groundwater-quality monitoring well stations in the National Water Quality Assessment Enhanced Trends Network Project.

3. Standard maintenance procedure for deployed high-frequency groundwaterquality sondes ................................................................................................................... 15

4. Troubleshooting guide for problems with groundwater-quality sensors .........................22

5. Optical nitrate sensor factors and impacts affecting accuracy and solutions................24

6. Useful nitrate metadata with expected ranges for optical sensor troubleshooting and data qualification

7. Parameter codes and reporting units for measured field parameters and nitrate at groundwater-quality monitoring stations

8. Sensor recalibration and data correction thresholds for high-frequency waterquality monitoring sensors deployed at groundwater- and surface-water quality stations

9. Maximum allowable limits guidance for correction of raw field-measured values of field parameters and nitrate for groundwater-quality monitoring stations and surface-water quality monitoring stations

1-1. Sonde measurement settings during laboratory experiments

1-2. Short-term and long-term precision of three water-quality sondes in $\mathrm{pH} 7$ and 1,000 microsiemens per centimeter $(\mu \mathrm{S} / \mathrm{cm})$ calibration standards and from time-series data collected at high-frequency groundwater-quality station USGS 364200119420001 from September 2013 to October 2017

\section{Conversion Factors}

U.S. customary units to International System of Units

\begin{tabular}{|c|c|c|}
\hline Multiply & By & To obtain \\
\hline \multicolumn{3}{|c|}{ Length } \\
\hline inch (in.) & 2.54 & centimeter $(\mathrm{cm})$ \\
\hline inch (in.) & 25.4 & millimeter $(\mathrm{mm})$ \\
\hline foot $(\mathrm{ft})$ & 0.3048 & meter $(\mathrm{m})$ \\
\hline \multicolumn{3}{|c|}{ Volume } \\
\hline gallon (gal) & 3.785 & liter (L) \\
\hline \multicolumn{3}{|c|}{ Flow rate } \\
\hline foot per hour (ft/h) & 0.3048 & meter per hour $(\mathrm{m} / \mathrm{h})$ \\
\hline gallon per minute (gal/min) & 0.06309 & liter per second $(\mathrm{L} / \mathrm{s})$ \\
\hline
\end{tabular}

Temperature in degrees Celsius $\left({ }^{\circ} \mathrm{C}\right)$ may be converted to degrees Fahrenheit $\left({ }^{\circ} \mathrm{F}\right)$ as follows:

$$
{ }^{\circ} \mathrm{F}=\left(1.8 \times{ }^{\circ} \mathrm{C}\right)+32 .
$$




\section{Datum}

Vertical coordination information (land-surface datum) is referenced to North American Datum of 1988 (NAVD 88)

\section{Supplemental Information}

Specific conductance is given in microsiemens per centimeter at 25 degrees Celsius $(\mu \mathrm{S} / \mathrm{cm}$ at $\left.25^{\circ} \mathrm{C}\right)$.

Concentrations of dissolved oxygen in water are given in milligrams per liter ( $\mathrm{mg} / \mathrm{L})$. Milligrams per liter is equivalent to parts per million (ppm).

$\mathrm{pH}$ is given in standard $\mathrm{pH}$ units.

Concentrations of nitrate in water are given in $\mathrm{mg} / \mathrm{L}$ and labelled as nitrite plus nitrate, as nitrogen $\left(\mathrm{NO}_{3}\right.$ as $\left.\mathrm{N}\right)$.

\section{Abbreviations}

CIV

corrected instantaneous value (NWIS-TS)

CRP

Continuous Records Processing (USGS)

DIW

deionized water

DCP

data collection platform

DO

dissolved oxygen

ETN

Enhanced Trends Network (NAWQA)

MAL

maximum allowable limit

NAWQA

National Water Quality Program (USGS)

NFM

National Field Manual for the Collection of Water-Quality Data (USGS)

NIST

National Institute of Standards and Technology

NWIS-TS

National Water Information System-Time Series database (USGS)

$\mathrm{QA}$

quality assurance

RIV

raw instantaneous value (NWIS-TS)

RMS

Records Management System (USGS)

RSD

relative standard deviation

$\mathrm{SC}$

specific conductance

SD

standard deviation

SIMS

Site Information Management System (USGS)

VFD

variable flow drive

USGS

U.S. Geological Survey 


\title{
Guidelines and Standard Procedures for High-Frequency Groundwater-Quality Monitoring Stations-Design, Operation, and Record Computation
}

\author{
By Timothy M. Mathany, John Franco Saraceno, and Justin T. Kulongoski
}

\section{Abstract}

High-frequency water-quality monitoring stations measure and transmit data, often in near real-time, from a wide range of aquatic environments to assess the quality of the Nation's water resources. Common instrumentation for highfrequency water-quality data collection uses a multi-parameter sonde, which typically has sensors that measure and record water temperature, specific conductance, $\mathrm{pH}$, and dissolved oxygen. Nitrate, turbidity, and fluorescent dissolved organic matter can also be monitored at high frequency.

Groundwater-quality monitoring stations provide highresolution time-series data to improve understanding of the timing of water-quality changes in the subsurface, especially for aquifer systems with short groundwater-residence times. High-frequency time-series data are used to monitor surfacewater to groundwater interaction, quantify contaminant transport rates, and study water-quality variability in relation to variability of precipitation and groundwater pumping rates. High-frequency monitoring for contaminants or their surrogates have the added benefit of providing an early warning to protect valuable or sensitive aquifer resources. High-frequency time-series data also reveal short-term trends in groundwater quality, which may not be identifiable from monthly or annual sampling programs which facilitate the interpretation of decadal conditions. Systematic application of water-quality sonde operational procedures and a standard record-computation process are part of the required quality assurance for producing and documenting complete and accurate high-frequency groundwater-quality monitoring records. To collect quality high-frequency groundwater times-series data, water-quality sondes and sensors require careful field operation, cleaning, and calibration, as well as specific procedures for data correction, evaluation, review, and publication of final records.

This report provides guidelines for groundwater-quality monitoring station set-up, the use of water-quality sondes and sensors for high-frequency groundwater-quality monitoring, and updates the guidance pertaining to standardized records computation procedures for a wide range of groundwater environments. This report builds on previous continuous surface-water-quality monitoring guidance documentation for water temperature, specific conductance, $\mathrm{pH}$, dissolved oxygen, and nitrate. The specific groundwater-quality monitoring guidelines presented in this report address station selection, design, installation, and operations; sonde and sensor inspections and cleaning and calibration methods; troubleshooting procedures; data evaluations, data corrections, and record computations; and record review, approval, and auditing procedures for the groundwater environment.

\section{Introduction}

The goal for high-frequency monitoring of groundwater quality is to obtain the most representative and complete record possible. High-frequency monitoring of water-quality parameters, such as water temperature, specific conductance (SC), $\mathrm{pH}$, dissolved oxygen (DO), nitrate, and turbidity, by the U.S. Geological Survey (USGS) has focused on subaerial waters ranging from freshwater streams and rivers to brackish estuaries, to saline bodies including bays, and oceans (VanMetre and others, 2012, 2015; VanMetre and Journey, 2014; Oelsner and others, 2017; https://cida.usgs.gov/quality/ rivers/sites). These studies provide insight into the timing and magnitude of changes in water quality and the processes driving these changes. A major focus of the National Water Quality Program (NAWQA) Cycle 3 (Rowe and others, 2010, 2013; https://NAWQAtrends.wim.usgs.gov/Decadal/) is to identify the time scales during which groundwater quality changes and the factors driving those changes. Beginning in 2013, the USGS NAWQA Program established the Enhanced Trends Network (ETN) Project to collect high-frequency water-quality data at 25 groundwater stations in 8 major aquifer systems throughout the United States (Arnold and others, 2016, 2017; Saraceno and others, 2018). 
High-frequency groundwater-quality time-series data are used to (1) reveal short-term trends in groundwater quality, which may not be identifiable from monthly or annual sampling programs which facilitate the interpretation of decadal conditions, (2) monitor surface-water to groundwater interaction, (3) quantify contaminant transport rates, and (4) study water-quality variability in relation to variability of precipitation and groundwater pumping rates, for example. Additionally, high-frequency monitoring for contaminants or their surrogates have the added benefit of providing an early warning to protect valuable or sensitive aquifer resources.

Changes in water quality in many groundwater aquifers are relatively slow compared to those in surface water, and the magnitude of the changes also are often less in groundwater than in surface water (https://nawqatrends.wim.usgs.gov/ swtrends/; https://nawqatrends.wim.usgs.gov/Decadal/; Oelsner and others, 2017; Opsahl and others, 2017). Collecting and evaluating high-frequency groundwater-quality timeseries data thus requires specific protocols and procedures which differ from existing water-quality monitoring guidance. The USGS Techniques and Methods Report 1-D3 (Wagner and others, 2006) provides a guide to set up continuous (hereinafter referred to as high frequency) surface-waterquality stations and includes minimum guidelines for the calibration of water-quality sensors and correction of highfrequency surface-water-quality time-series data.

The techniques for setting up a high-frequency groundwater-quality station to measure representative aquifer conditions are not addressed in the surface-water quality station set-up instructions in Wagner and others (2006), including, techniques for groundwater-quality station selection, station design, selection of instrumentation, and monitoring equipment installations. Additionally, when the minimum calibration criteria and data correction guidelines from Wagner and others (2006) were applied to the NAWQA ETN Project groundwater-quality time-series data records, the larger recalibration and data-correction tolerance values obscured the variability in the groundwater data, and this demonstrated that the recalibration and correction tolerance values needed to be smaller in order to identify changes in groundwater chemistry in the data.

In response to the lack of groundwater specific guidelines, this report was developed for setting up a highfrequency groundwater-quality monitoring station for a variety of well types, and to refine recalibration and data-correction guidance to correct groundwater-quality time-series data records. The guidelines and procedures herein will enable the accurate measurement, correction, and publication of high-frequency groundwater-quality monitoring data from low-velocity and rapidly changing flow systems, conditions characteristic of the principal aquifer systems throughout the United States (U.S. Geological Survey, 2000; Lapham and others, 2005).

\section{Purpose and Scope}

This report provides specific guidelines and procedures for the establishment and operation of a high-frequency groundwater-quality monitoring station and includes the following:

- Station selection, station design, description and selection of instrumentation, and monitoring equipment installations.

- Field procedures for data quality assurance (QA), including troubleshooting, cleaning, and calibrating of sensors.

- Office QA procedures, including groundwater-quality data reporting and review.

The updates to the calibration criteria and data corrections guidelines presented in this report provide a uniform set of procedures to correct groundwater-quality data in a meaningful way, and thus, to aid the evaluation of groundwater-quality time-series data for trends. These guidelines and procedures could require adaptation and modification by field and office personnel according to local groundwater conditions. Knowledge of the operation of the groundwater-monitoring equipment and of the groundwater-aquifer system form the core of the waterquality data evaluation process. Examples of the application of scientific judgment in the evaluation of groundwaterquality time-series data records are discussed and are, by necessity, station specific. In addition, specific examples are included that demonstrate a variety of environmental and mechanical conditions that affect the groundwater-quality data evaluation process.

Techniques specific to turbidity and chromophoric dissolved organic matter fluorescence (fDOM), which are frequently measured and monitored in a surface water environment, are not discussed in this report. For more information and guidance on turbidity and fDOM waterquality parameters, see Wagner and others (2006) and Pellerin and others (2013). 


\section{Guidelines and Standard Procedures}

\section{High-Frequency Groundwater-Quality Monitoring Station Selection}

When selecting a well for a high-frequency groundwater monitoring station, there are several important considerations, including whether the well is representative of aquifer conditions, is easily accessible, and has documentation of well construction. The well must be adequately purged, by daily (or regular interval) pumping, artesian flow, or exhibit high groundwater flow rate, in order to be representative of aquifer conditions when sampled. The well site should have a permissible, convenient location providing direct vehicle and personnel access to the station (and near the well) for regularly scheduled site visits and equipment service. Adequate documentation of the well construction and structural integrity of the wells is important to ensure that wells are monitored at the desired depths, producing appropriate volumes of groundwater, and not leaking from other zones of the aquifer (Saraceno and others, 2018).

Once an appropriate well is selected, as part of the data management plan, standard USGS procedures for groundwater site establishment should be followed (Cunningham and Schalk, 2011). This includes working with USGS Water Science Center Local Database Managers (LDMs) to set up the high-frequency groundwater-quality monitoring station in the USGS National Water Information System Time Series (NWIS-TS) database (see section, "Setting Up a New HighFrequency Groundwater-Quality Monitoring Station in the NWIS-Time Series Database").

Other considerations, such as legal agreements and data releases, that can arise when working with different types of well owners (for example, municipal, domestic, or even the USGS), are beyond the scope of this report.

\section{High-Frequency Groundwater-Quality Monitoring Station Design}

The design of a high-frequency groundwater-quality monitoring station varies according to the aquifer being studied. A major consideration in the station design is whether the well is actively pumped (with a submersible pump) or passively monitored (with a submerged water-quality sonde or sensor). In the following sections, a range of station designs, and equipment used to monitor groundwater quality at high frequency at high-capacity supply wells, domestic supply wells, and monitoring wells are outlined. This work focuses on describing high-frequency monitoring of groundwater in aquifers (1) ex situ (at the surface) where active pumping is used to monitor groundwater using techniques that ensure the water is representative of the aquifer or (2) in situ (inside the borehole) where passive monitoring of the aquifer occurs directly.

\section{Station Design at Actively Pumped Wells}

Most of the methods for high-frequency groundwater monitoring described here rely upon actively pumping wells or free-flowing artesian wells (to adequately purge the wellbore to USGS National Field Manual [NFM] standards; Wilde, 2006a); water-quality sondes deployed ex situ; and diversion of groundwater from the well to the water-quality sonde for field parameter measurement.

There are three categories of actively pumped wells: (1) wells that are continuously pumped for high-capacity supply, (2) wells that are episodically pumped for domestic supply and need a means to determine when the pump is on, and (3) monitoring wells that are episodically pumped by way of dedicated submersible pump with a mechanism for activating the pump. For categories 1 and 2 wells, the high-frequency groundwater-quality station design utilizes the existing water distribution system used by the operator or owner to push the water through the plumbing, to the sample port, and past the water-quality sondes. For category 3 (monitoring) wells, the water distribution system will need to be constructed, including installing a submersible pump and the related plumbing, to get water from the well to the waterquality sonde (Saraceno and others, 2018).

The system design for all three actively pumped well categories includes a water-quality sonde installed ex situ, equipped with a flow cell at (or near) the wellhead to collect the water-quality data, and connections to the equipment (electrical and data) supporting data collection and transmission. The equipment used to support the data collection includes fittings, tubing, a data collection platform (DCP) with either cellular or satellite telemetry, and if electric power is not available, a solar or other renewable power system (Saraceno and others, 2018; figs. 1, 2).

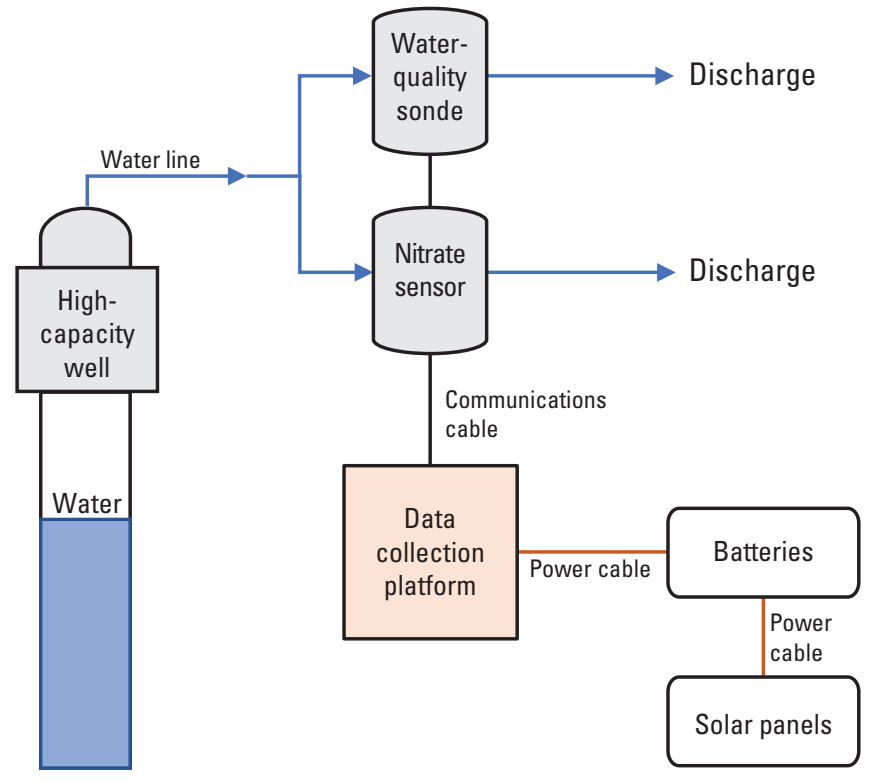

Figure 1. Example of a high-frequency groundwater-quality monitoring system for a single well station. 


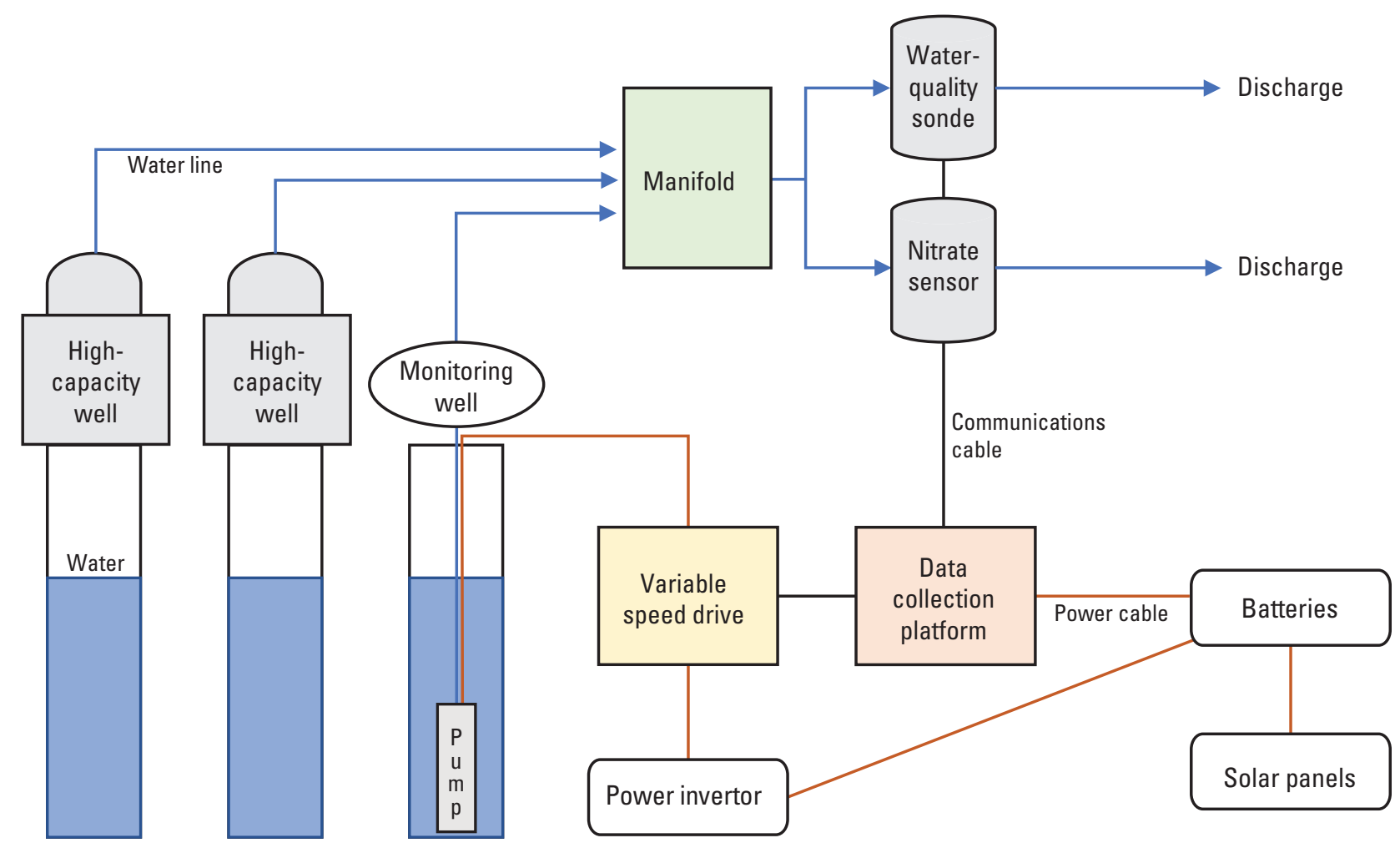

Figure 2. Example of a high-frequency groundwater-quality monitoring system for a multiple well station.

\section{Well Purging}

To ensure that the groundwater monitored by the waterquality sonde at actively pumped wells is representative of aquifer conditions, wells should be adequately purged prior to data collection. At monitoring stations located at highcapacity supply wells, which pump groundwater 24 hours a day, 7 days a week, or free-flowing artesian wells, adequate well purging is not an issue, as they are constantly purged. However, for sites which pump intermittently (high-capacity or domestic supply), or monitoring wells, verification of adequate well purging is very important, as pumping is often sporadic. By removing standing water from the borehole, well purging reduces chemical and biochemical artifacts caused by the materials and practices used for well installation, well construction, and well development, and reactions within an open borehole or annular space between a well casing and borehole wall. Well purging also conditions the monitoring equipment with well water, forming a continuum with that of representative groundwater withdrawal. Withdrawal is the process by which representative groundwater is transported for collection (monitoring) after the well has been adequately purged (Wilde, 2006a).

To ensure adequate well purging, evacuate a minimum of three volumes of casing water to implement the well-purge procedure (or accepted modifications) described in USGS
NFM Section 4.2.3 (Wilde, 2006a). Well purge calculations are summarized in the following equations and are presented on the USGS High-Frequency Groundwater-Quality Field Form as fillable fields that auto-calculate (appendix 2):

$$
V=(G P F C)(H)
$$

where

$\begin{aligned} V & \text { is volume of water in well, in gallons, } \\ H & \text { is height of water column, in feet, and } \\ G P F C & \text { is gallons per foot of casing (table 1). }\end{aligned}$

$$
P V=(n)(V)
$$

where

$P V \quad$ is purge volume, in gallons, and

$n \quad$ is number of well volumes to be removed during purging.

$$
A P T=P V / Q
$$

where

$$
\begin{aligned}
& A P T \text { is approximate purge time, in minutes, and } \\
& Q \text { is estimated pumping rate, in gallons per } \\
& \text { minute. }
\end{aligned}
$$


Table 1. Gallons of water per foot of well casing.

[Gallons of water per foot of well casing from Wilde (2006a). Abbreviation: D, diameter, in inches]

\begin{tabular}{cc}
$\begin{array}{c}\text { Well casing diameter } \\
\text { (D) }\end{array}$ & $\begin{array}{c}\text { Gallons of water } \\
\text { per foot of casing }\end{array}$ \\
\hline 1.0 & 0.04 \\
1.5 & 0.09 \\
2.0 & 0.16 \\
3.0 & 0.37 \\
4.0 & 0.65 \\
4.5 & 0.83 \\
5.0 & 1.02 \\
6.0 & 1.47 \\
8.0 & 2.61 \\
10.0 & 4.08 \\
12.0 & 5.88 \\
24.0 & 23.50 \\
36.0 & 52.90 \\
\hline
\end{tabular}

Calculating and documenting the well purge is done routinely when setting up a high-frequency groundwaterquality monitoring station at actively pumped wells (appendix 2). Of particular importance in this calculation is the purge volume and the estimated pumping rate of the water discharging from the well, from which the appropriate pumping time for purging nonrepresentative water from each well is determined.

\section{Water-Quality Sondes}

The USGS routinely measures water temperature, SC, $\mathrm{pH}$, and DO using a multi-parameter water-quality sonde (hereinafter referred to as sonde). Given the slow groundwater flow rates and response times compared to surface-water bodies, sondes with high accuracy and precision and low sensor measurement drift are recommended to resolve the subtle and slowly changing variations in groundwater quality. Sonde operation, maintenance, and calibration of each waterquality sensor should be performed according to specific guidelines as described in this document, general guidelines in chapter A6 (Wilde, variously dated) and Section 6.8 of the USGS NFM (Gibs and others, 2007), and detailed manufacturer guidelines.

Ideally, the sonde should be installed in the borehole beneath the pump, in situ, so fresh water is drawn past the sonde and measured. However, it is often not possible to install the sonde below the pump in high-capacity supply, domestic supply, or monitoring wells, and as such, the sonde may be installed ex situ, as close to the wellhead as possible. The sonde should be connected to a DCP to enable programmed operation of the sonde, telemetry of data, and communication for troubleshooting. An ex situ sonde should be installed vertically in a flow cell, in a protected location to minimize disturbance, and the flow cell should be supported to prevent fatigue on the instrument housing. Flow cells were chosen for high-frequency groundwater-quality monitoring stations because they are the standard equipment used for many years by the USGS for ex situ logging of field-parameter stability logs before collecting discrete groundwater-quality samples (Wilde, variously dated).

At actively pumped wells, the flow cell (holding the sonde) should be connected to the discharge of the well, generally from a sample port or hose-bib fitting, with black (or opaque) tubing to inhibit the growth of algae. An antisiphon check valve should be installed to prevent groundwater that contacted the tubing and the water-quality monitoring equipment from flowing back into the well. Flow rate should be regulated by the sample port, hose-bib fitting, or check valve to $1-2$ gallons per minute (gal/min; for most sondes) as higher flow rates through the flow cell create high pressure and may damage the water-quality sensors. Tubing should be constructed from materials that will not contaminate either the withdrawn water or the water system. Select tubing materials in accordance with project-specific QA plans and USGS standard operating procedures. If there is considerable distance between the wellhead and the sonde, then give ample time to purge the tubing and flow cell of stagnant water, to ensure representative water is monitored.

Sondes deployed ex situ, in outdoor settings, are often subject to the influence of ambient environmental temperatures on groundwater as it travels through the tubing to reach the sonde. To a lesser extent, sondes deployed ex situ, in a protected environment (for example, a well house, garage, or similar) are also subject to ambient environmental temperatures. As a result, water temperatures measured by the sonde may not accurately reflect aquifer-representative groundwater conditions. To minimize the influence of ambient temperature effects on the groundwater before it reaches the sonde, it is recommended that all tubing from the wellhead to the sonde be wrapped in insulation (foam or similar) no matter the station setup. For long tubing runs, in outdoor settings, the tubing from the wellhead can be buried or placed in a conduit (in addition to the insulating foam wrap), to further reduce potential temperature fluctuations and to protect the tubing. For stations under the influence of extreme temperature fluctuations and harsh environments, the insulating of the flow cell and the sonde is also recommended. In colder climates, operating a space heater, or using heating tape around the tubing and flow cell may be required in the winter to prevent the system from freezing. 
To prevent the analysis of stagnant or back-flow water by the sonde, install flow-indicator and pump-activity switches (for example, a magnetic deflectometer; fig. 3) (Saraceno and others, 2018). These switches signal the DCP to only collect data if the pump is operating and groundwater discharge is high enough to guarantee representative water from the wellhead. The flow indicator position determines when waterquality data are recorded in the DCP (Saraceno and others, 2018) and provides an indicator flag to the USGS NWIS-TS (hereinafter referred to as NWIS-TS) database for data qualitycontrol and sensor troubleshooting purposes.

\section{Optical Nitrate Sensors}

Although many types of nitrate sensors are commercially available, an optical sensor is recommended for highfrequency groundwater-quality monitoring stations because of the higher accuracy, broader concentration range, and stability of optical methods relative to other technologies (for example, ion selective electrode and wet chemistry; Pellerin and others, 2013; Huebsch and others, 2015). The accuracy of an optical nitrate sensor is largely determined by its optical path length, hence, a sensor with an optical path length that enables measurement of the full wavelength range of expected nitrate concentrations is recommended to maximize measurement accuracy and precision (Pellerin and others, 2013; Huebsch and others, 2015). Although dualwavelength optical spectrometers are available for nitrate monitoring, a multi-wavelength sensor that produces a full ultra-violet (UV) spectrum could provide more accurate nitrate measurements in the presence of interfering substances (Pellerin and others, 2013; Huebsch and others, 2015). In addition, if the optical nitrate sensor cannot be deployed by suspension inside the well casing (Huebsch and others, 2015; MacDonald and others, 2017; Opsahl and others, 2017), it is recommended that the optical nitrate sensor be submerged in a large bath (external container with constant flow through of well water; fig. 4) or encased in a large insulated flow cell (fig. 5) to minimize bias from temperature oscillations and avoid shut down of the sensor lamp because of overheating (Pellerin and others, 2009; Saraceno and others, 2018). Clean the external container regularly to reduce the accumulation of debris and potentially corrosive substances. In addition to the recommendations presented in this report, be sure to operate, maintain, and calibrate the optical nitrate sensor according to guidelines in Pellerin and others (2013).

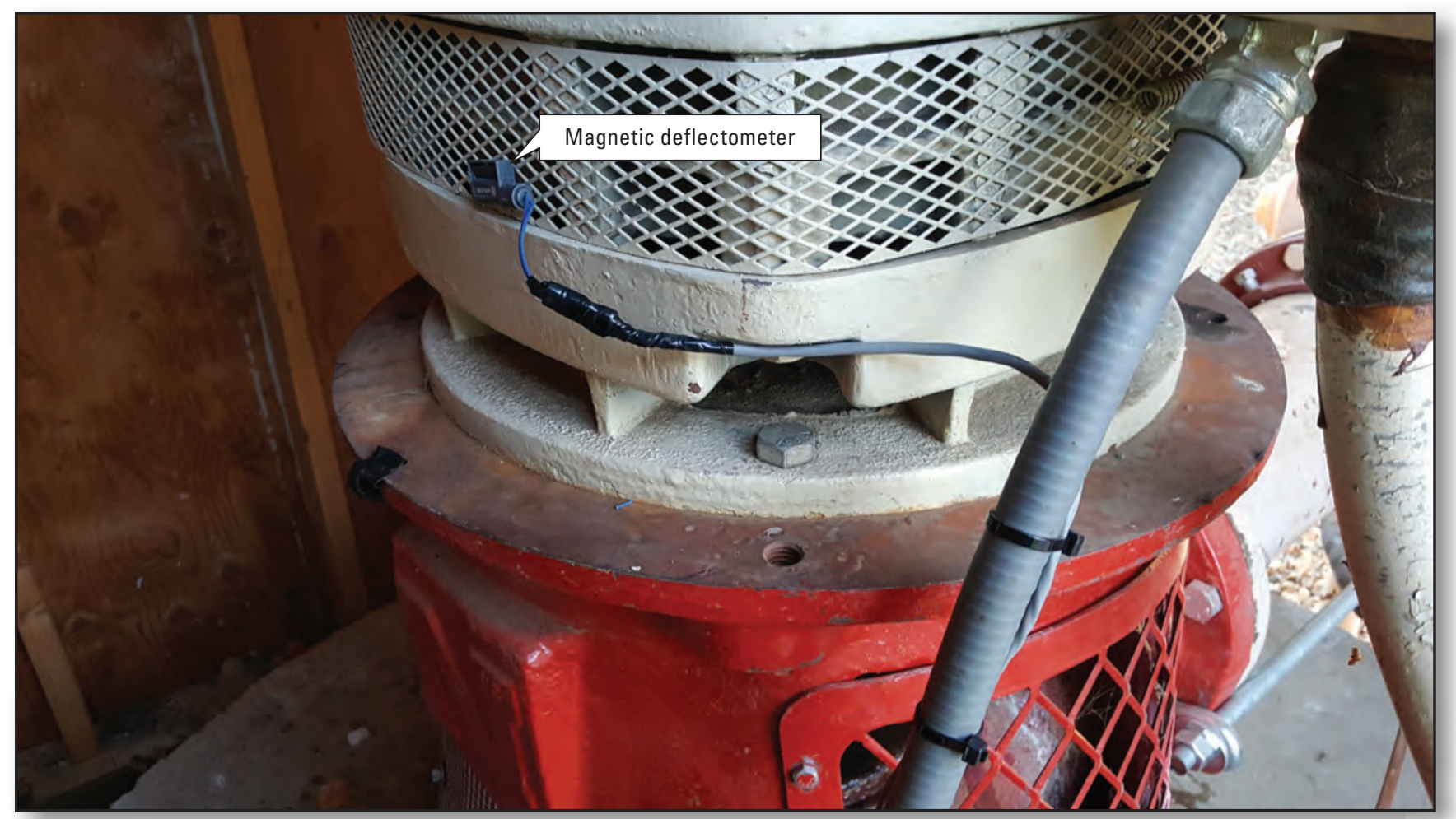

Photograph by John Franco Saraceno, U.S. Geological Survey.

Figure 3. Pump operation magnetic deflectometer installed at USGS well 364200119420001, Fresno, California. 


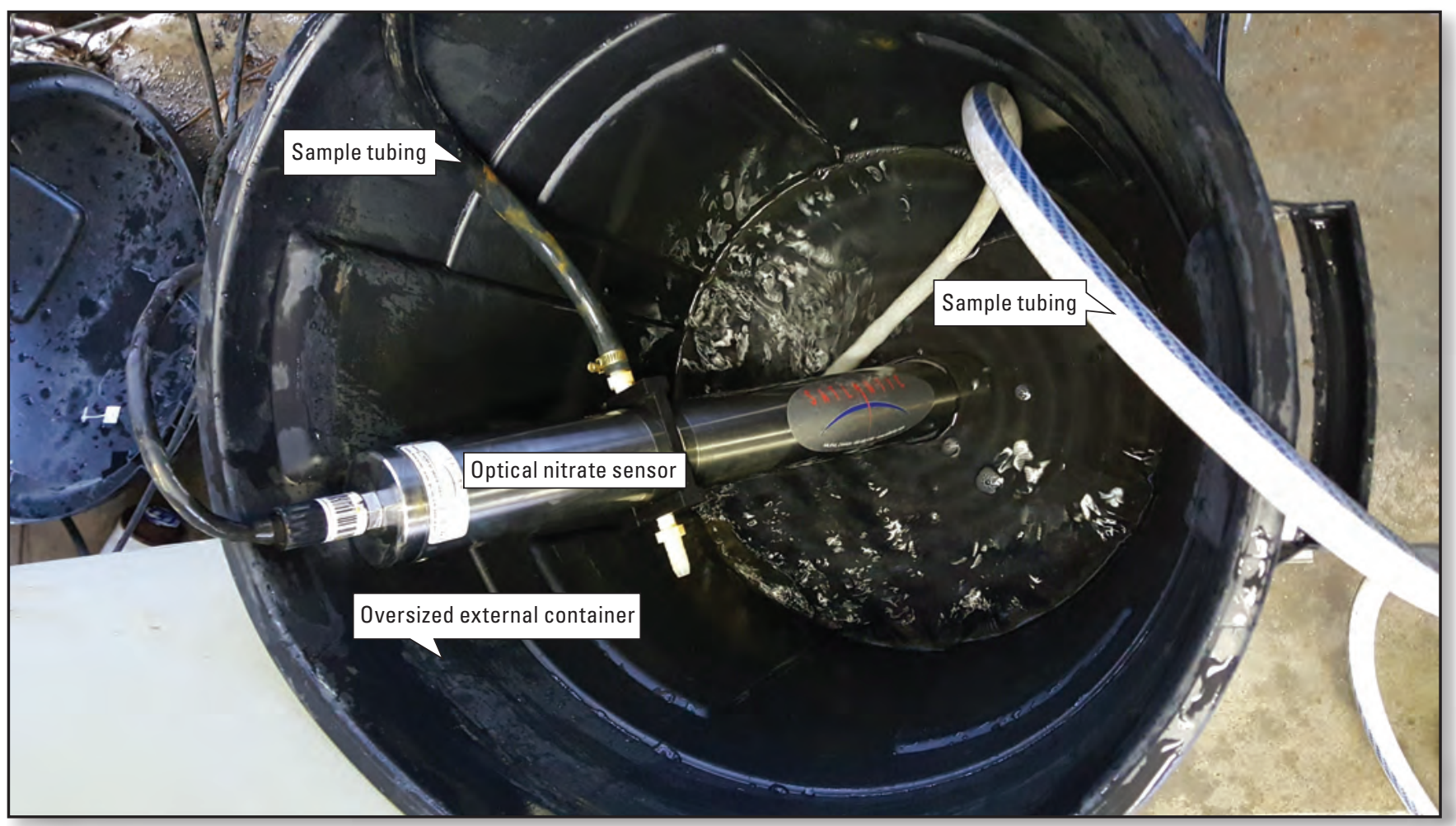

Photograph by John Franco Saraceno, U.S. Geological Survey.

Figure 4. Optical nitrate sensor configuration at multiple well station USGS 364200119420001, 364200119420002, and 364200119420003, Fresno, California.

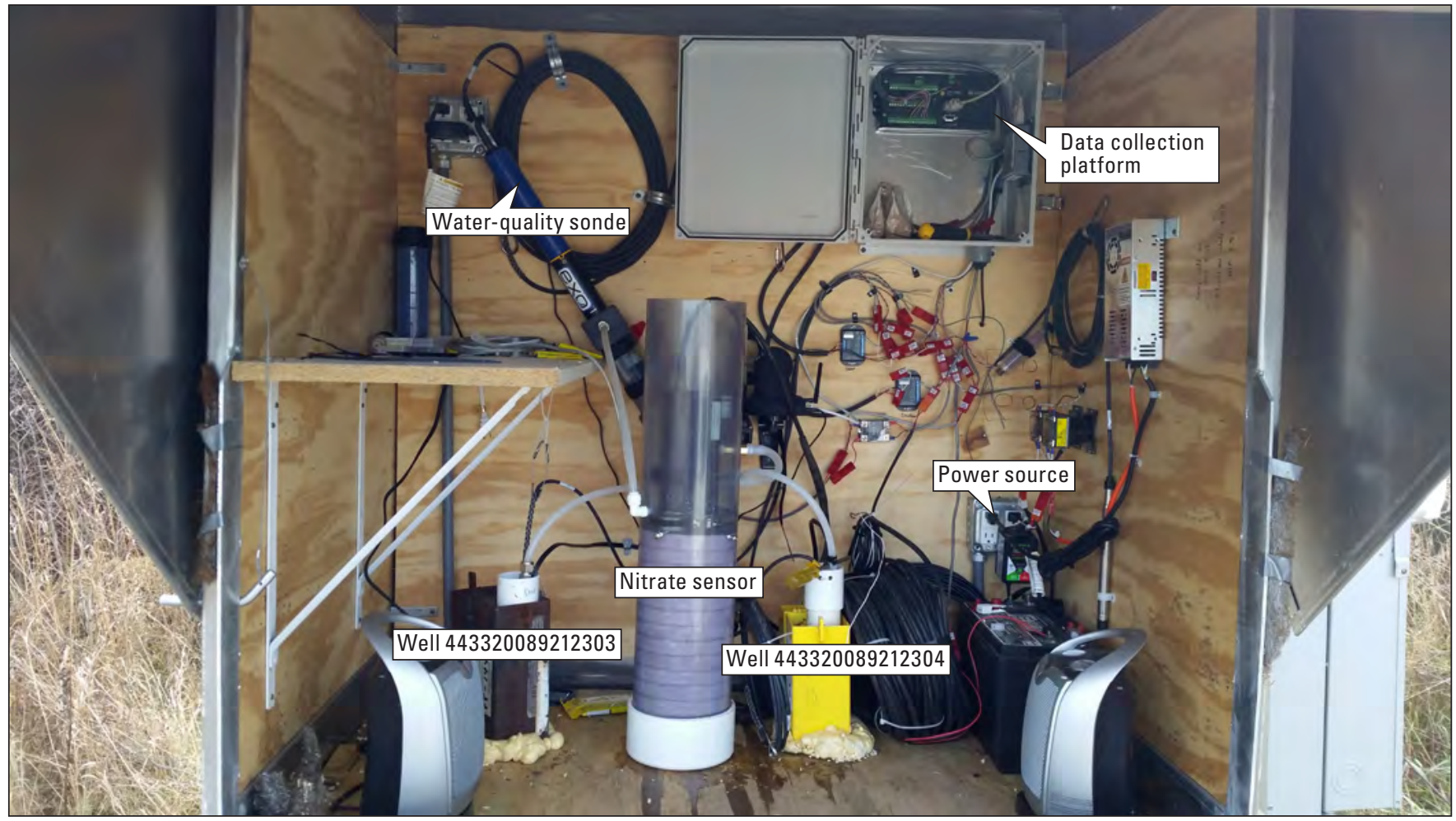

Photograph by Jason Smith, U.S. Geological Survey

Figure 5. Instrumentation shelter and equipment configuration at multiple-monitoring well station USGS 443320089212303 and 443320089212304, near Spring Green, Wisconsin. 


\section{Data Collection Platform}

The DCP controls the water-quality measurement system and is programmed to manage the data collection by the sonde, telemetry of data, system power supply, solenoids valves, and monitors the system (figs. 5-7, 9, 10). To remotely troubleshoot the measurement system, the DCP may be equipped with 2-way telemetry, such as a cellular modem which allows for remote communication with the equipment. Modems occasionally lock when the cellular signal quality (fidelity and strength) is periodically diminished. To remedy this lock issue, periodically interrupt power to the modem with a DCP triggered relay or similar switching device to reset the connection to the cellular network (Saraceno and others, 2018).

Several DCP types are available for the high-frequency groundwater-quality monitoring systems, including the WaterLOG $^{\circledR}$ XL Series 522+ data logger (YSI Incorporated, 2015) with GOES satellite transmitter (Design Analyses Associates Incorporated, 2014) and the Campbell Scientific CR1000 (Campbell Scientific Incorporated, 2018). Selection of DCP depends upon the needs of the system; which include programmability and communication with interfacing hardware, such as modems, monitoring well pumps, solenoid valves, sondes, and nitrate sensors; as well as familiarity of the user with the DCP specific programming language.

\section{High-Capacity Supply Well Installations}

To accurately monitor high-capacity supply wells (such as municipal, industrial, or irrigation wells) at high frequency, attach tubing to the discharge from the well as close to the wellhead as possible, before any water treatment processes, and routed to the flow cell (holding the sonde) with the minimum possible length of tubing. Install all water-quality and support instrumentation in a secure, sheltered location, typically in a well house, or enclosure (fig. 6). High-capacity supply wells often operate 24 hours per day, 7 days a week, or at set intervals predetermined by the well operator. These supply wells will often provide the most continuous and complete water-quality record because data are collected whenever the well is actively pumping. High-capacity supply wells evacuate large volumes of water in a short amount of time, so there is minimal concern about satisfying the requirements of the standard three-volume purge procedure for collecting representative groundwater-quality measurements (Wilde, 2006a). A potential disadvantage of high-capacity supply wells is the potential for the loss of hydrogeologic resolution; that is, such wells typically have long screened intervals that may (or may not) result in monitored waters originating from multiple aquifers or aquifer zones that could have different water chemistry. Interview the well operators to gather enough information, before selecting a high-capacity supply well, to gain confidence the well can fulfill all scientific

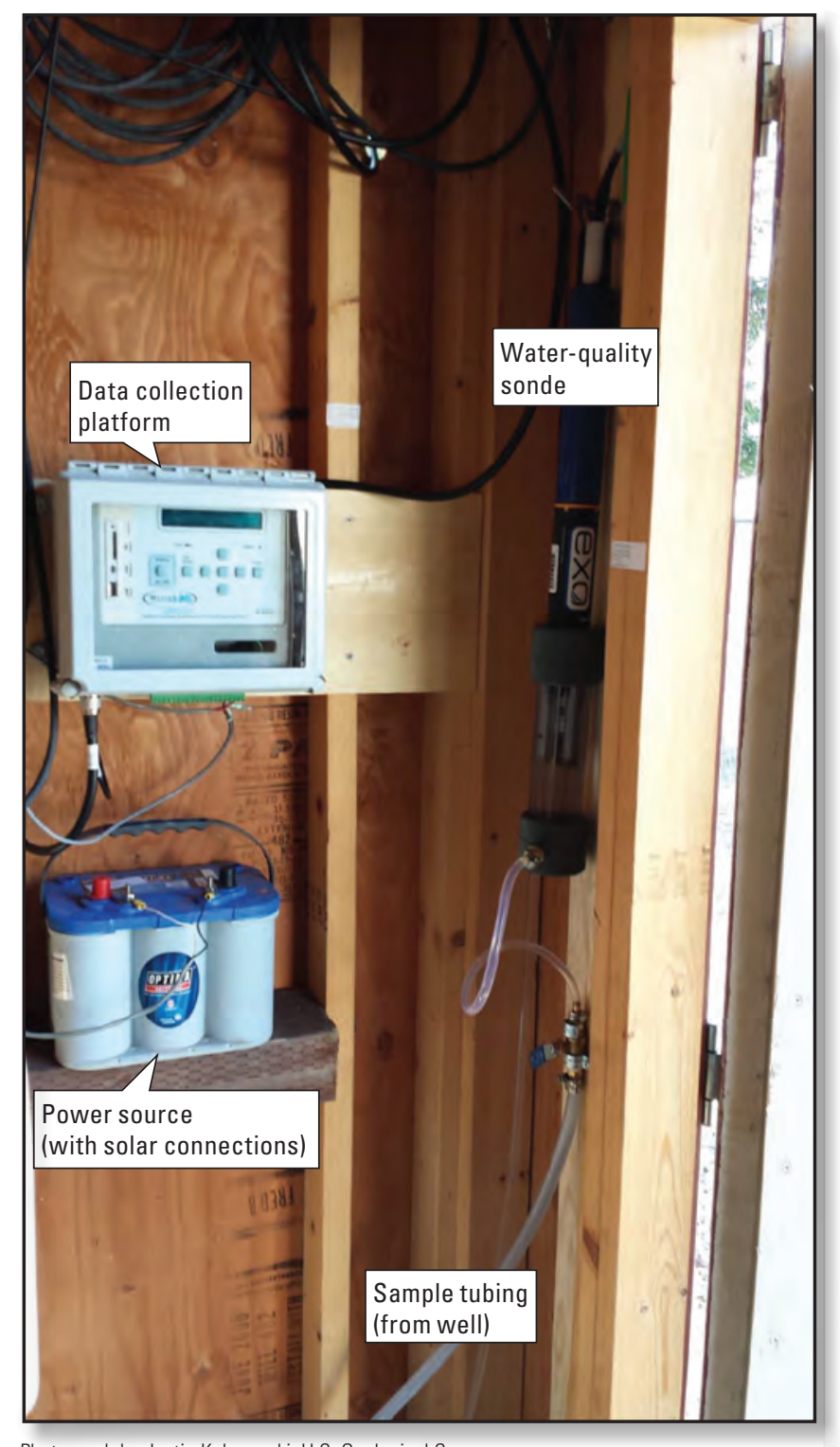

Photograph by Justin Kulongoski, U.S. Geological Survey.

Figure 6. Original instrumentation configuration at high-capacity supply well station USGS 364200119420001, Fresno, California.

and project specific high-frequency groundwater-quality monitoring goals.

Accurate well-pumping records are required for record computations at high-capacity wells and should always be requested from the well operator. After the pumping records are obtained, the non-pumping periods can be eliminated from the water-quality record during the record-computation process (see section, "Pre-Processing Corrections"). If pumping records are not collected by the well operator, a sensor to detect pump activity (for example, current sensor or deflectometer; fig. 3) could be installed and the data logged through the DCP. 
If multiple high-capacity supply wells are monitored with a single set of instrumentation (fig. 2), a non-monitoring time interval should be selected after changing the inflow source to ensure complete purging of the water-quality monitoring system so there is no mixing of groundwaters between the wells (Saraceno and others, 2018).

\section{Domestic Supply Well Installations}

Domestic supply wells begin pumping groundwater when demand is triggered from a pressure tank, storage tank, or similar water-storage device. To accurately monitor domestic wells at high frequency, install water-quality and support instrumentation in a protected location at (or near) the wellhead before the water supply enters any treatment systems (for example, water softeners, filters, or aerators) (fig. 7). The sonde should be placed in a flow cell that receives groundwater through a programmatically controlled solenoid valve that is as close to the wellhead as possible, ideally before the water supply enters storage devices (for example, pressure tanks or cisterns).

Domestic supply wells often pump at lower rates than high-capacity supply wells, so there is a concern about purging enough well-casing volumes to ensure that monitoring measurements are representative of the aquifer water quality (Wilde, 2006a). To remedy this, activate the domestic well pump for a set time before collecting water-quality data. Work with the well owner to accomplish this by programming water uses (for example, run sprinkler systems, refill a swimming pool or pond) or discharging water using timers (or the DCP) to control a 24-volt direct current (DC) solenoid valve.

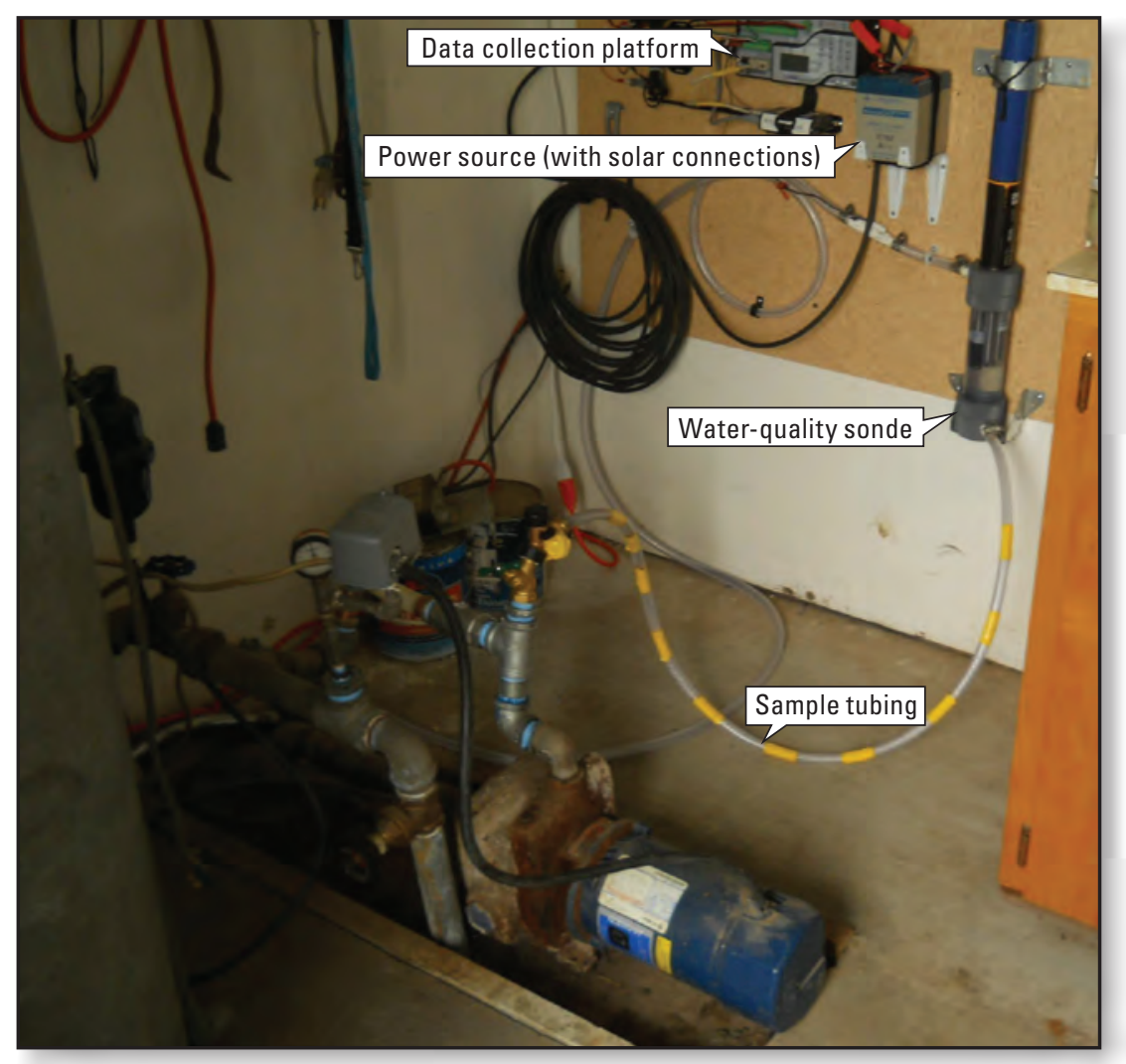

Photograph by Michael Sarantou, U.S. Geological Survey.

Figure 7. Instrumentation configuration at domestic well station USGS 454919119184701, Hermiston, Oregon. 
When appropriate water evacuation arrangements cannot be made (with well owner) or the water system is not configured to allow an instantaneous three well-casing volume purge, field personnel can immediately start monitoring water quality if the domestic supply well is being pumped continuously or daily (at regular intervals) for long enough to have removed three well-casing volumes (see section 4.2.3.B of the USGS NFM [Wilde, 2006a]). Some domestic supply wells will always be adequately purged for representative measurements (because of frequent use); for other domestic wells, the water-quality monitoring data collection could take place later in the day (to allow for regular domestic water use to purge the required amount of groundwater for representative measurements). Whatever the arrangement, setup the DCP to automatically open and purge the water-quality monitoring system before collecting water-quality data during the set "pump on" interval. When the high-frequency groundwaterquality time-series data records are processed from domestic supply wells, long periods of pumping and data collection may be identified and prioritized, whereas short bursts of pumping and data (less than 1 minute) may be screened out.

\section{Monitoring Well Installations}

High-frequency groundwater-quality data collection at monitoring (or observation) wells can be a challenge, depending on whether the monitoring well will be actively pumped or passively monitored.

\section{Actively Pumped Monitoring Well Installations}

Active high-frequency data collection of a monitoring well requires a dedicated submersible pump to pump groundwater to the ex situ sonde and related equipment installed at land surface (figs. 2, 5, 8-10).

\section{Submersible Pumps}

The submersible pump must have the capacity to achieve the three well-casing volume purge guidelines for collecting representative groundwater-quality measurements (Wilde, 2006a) on demand, unattended, and at regular intervals. Several types of submersible pumps are commercially available; an appropriate pump should be selected based on the depth-to-water table, depth and diameter of well, pump capacity, and estimated power consumption to evacuate three well-casing volumes of water before taking groundwaterquality measurements. No matter the groundwater pump type, the DCP should be set up to adequately purge the waterquality monitoring system before collecting water-quality data during the set "pump on" interval. Table 2 lists the well and groundwater pump information for the nine monitoring well stations in the NAWQA ETN Project, for reference and informational purposes.

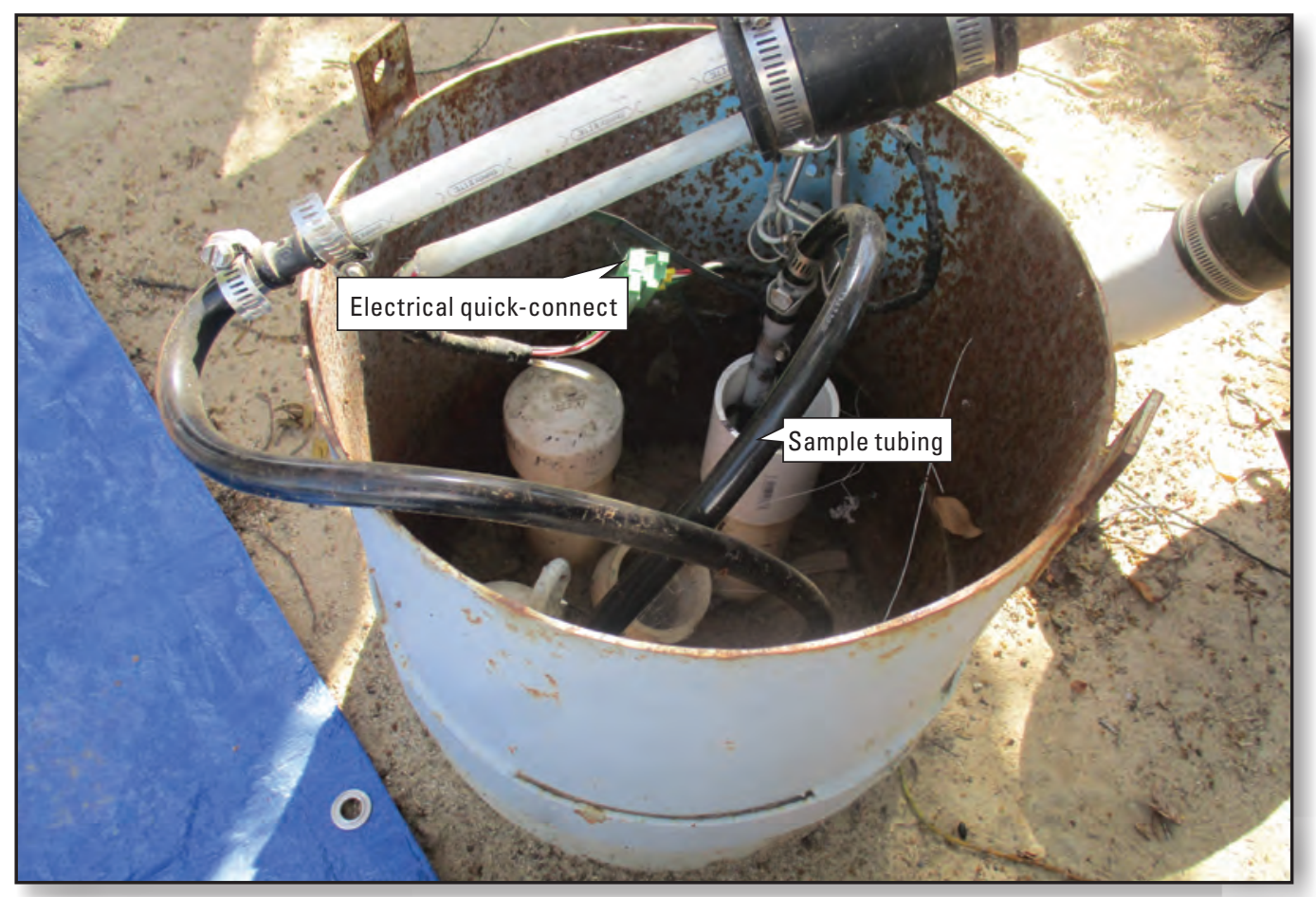

Photograph by Timothy Mathany, U.S. Geological Survey.

Figure 8. Wellhead at monitoring well station USGS 364200119420003 , Fresno, California. 


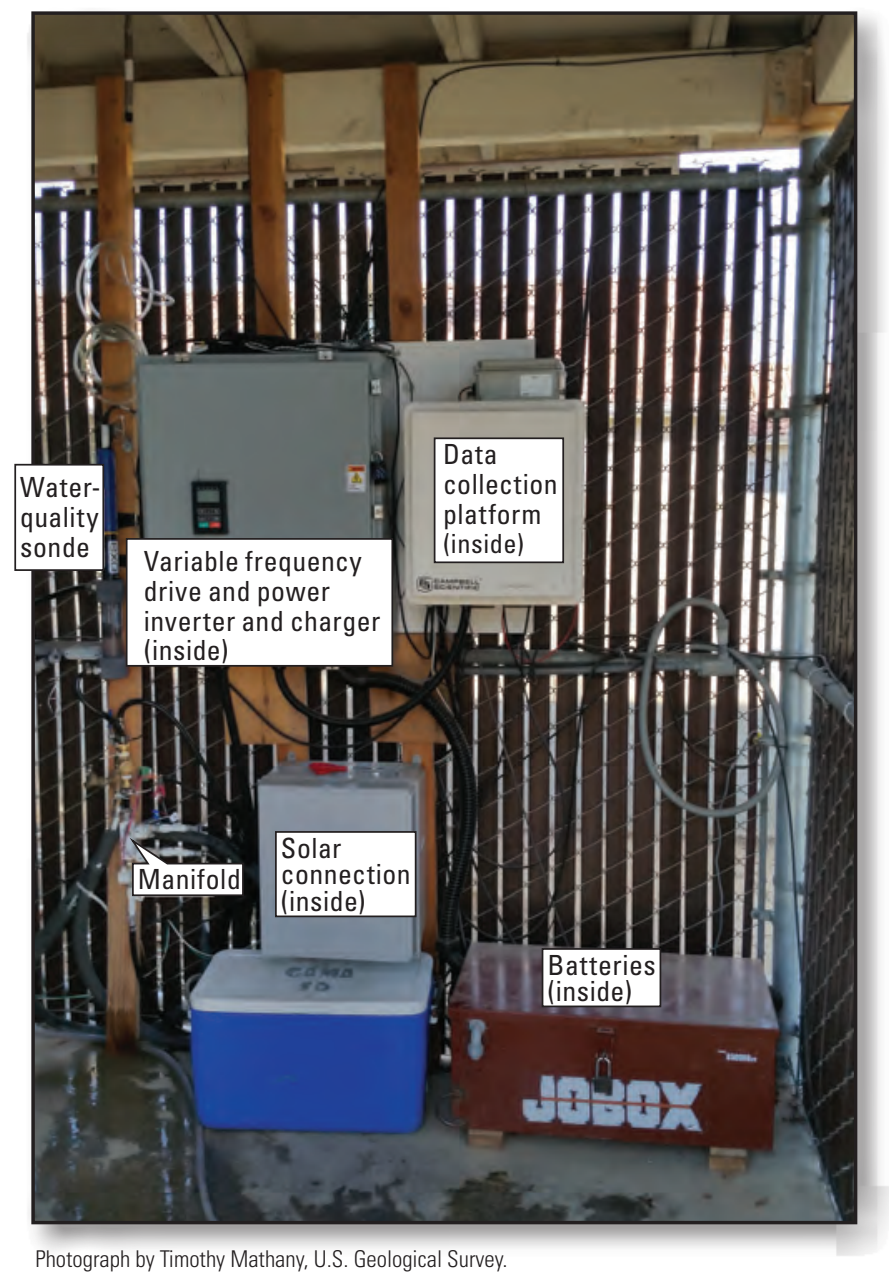

Figure 9. Instrumentation shelter and equipment configuration at multiple well station USGS 364200119420001, 364200119420002, and 364200119420003, Fresno, California.

For the deep monitoring wells in the NAWQA ETN Project, a Grundfos ${ }^{\circledR}$ Redi-Flo 2 or $3^{\text {TM }}$ (Redi-Flo 2/3) submersible alternating current (AC) induction pump was used (table 2). Redi-Flo 2/3s have a stainless-steel housing, stainless-steel and Teflon ${ }^{\circledR}$ motor construction, adjustable flow rate, and small (less than 2 in.) outer diameter. RediFlo 2/3s accompanying variable flow drive will not operate unattended, so a variable frequency drive (VFD) that meets the pump's requirements is necessary for proper operation. A three phase, 220-volt AC VFD with the ability to operate in variable frequency mode with a power rating of at least onehalf horsepower and capable of being triggered by a digital input signal (DCP compatible) is adequate for unattended monitoring with a Redi-Flo 2/3 (Saraceno and others, 2018).

For the shallow monitoring wells in the NAWQA ETN Project, a ProActive Environmental Products ${ }^{\mathrm{TM}}$, Poseidon ${ }^{\mathrm{TM}}$ 60 or 80 (Poseidon 60/80) submersible 12-volt DC induction pump was used (table 2). Poseidon 60/80s have a polyvinyl chloride (PVC) and polypropylene housing, stainless-steel motor construction, adjustable flow rate, and small (less than 2 in.) outer diameter. Poseidon 60/80s can be triggered directly by the DCP for unattended monitoring so a VFD is not needed.

Although necessary for actively pumped monitoring wells, submersible pumps have maintenance needs that can frequently turn into time consuming events for field personnel. For example, most pumps should be serviced bimonthly (if not sooner) to replenish internal lubricant (water) and to inspect gaskets and bearings for wear and replacement, as needed. To facilitate easier pump removal from the well during maintenance procedures, specialized couplings could be installed at the wellhead using a quick-release coupler in the tubing and an appropriate electrical plug or quick-connection in the wiring (fig. 11).

\section{Instrumentation Location}

The ex situ water-quality monitoring and support instrumentation should be installed in a secure location (for example, a well house, storage locker, Knaack ${ }^{\circledR}$ storage box, or other locked area; figs. 2, 9, 10). The secure location should create an environment for year-round monitoring by protecting the instrumentation from inclement weather and related issues. Creating a climate-controlled and adequately ventilated space is important for protecting water-quality monitoring equipment and electronics from damage caused by overheating or freezing conditions. Insulated boxes and lockers; building insulation and spray foam; and space heaters, heating tape, and fans (programmed to run at certain times) have all been used with success at stations in the NAWQA ETN Project (figs. 2, 9, 10).

Power

Significant power is required for the regular pumping, purging, and high-frequency data collection at a monitoring well. If electric line power is not available, a robust solar power system is required to generate the voltage (240 volts) required by submersible pumps (and VFDs) to operate (Saraceno and others, 2018). Proper solar panel placement is the most important factor when setting up a solar power system. Solar panels should be in an area with clear view of the solar day arc during mid-day hours of maximum power generation, which can be critical when wattage of solar panels is marginal for keeping all batteries charged. 


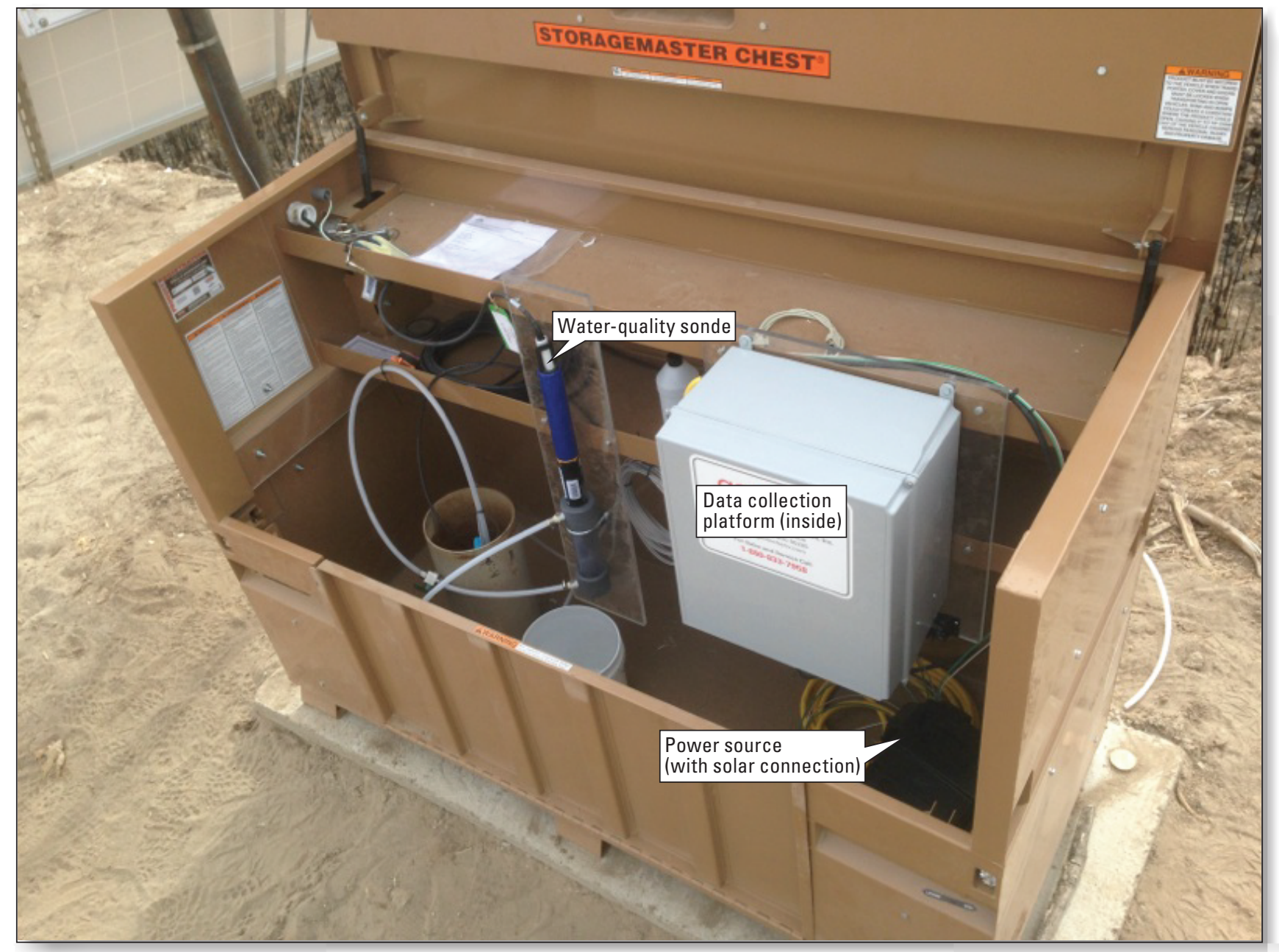

Photograph by Jay Cederberg, U.S. Geological Survey.

Figure 10. Wellhead, instrumentation shelter, and equipment configuration at monitoring well station USGS 323733107011002, Rincon Valley, New Mexico.

\section{Passive Monitoring Well Installations}

Passive in situ groundwater monitoring which relies upon groundwater flow in the borehole is appropriate for dynamic aquifer conditions such as shallow, karst, or rapidly recharging aquifers, or when scientific objectives require that highfrequency measurements are collected from static well water (Powell and Puls, 1993; Garinger and others, 2011; Huffman, 2014, 2015; MacDonald and others, 2017; Opsahl and others, 2017) and is also the preferred method for collecting the most accurate water temperature record (Wilde, 2006b). The basic station design for a passively monitored well involves deploying a sonde (or dedicated sensor) inside a borehole or well casing at a target depth, securing with appropriate hanging equipment, logging measurements, and transmitting water-quality data in real- or non-real-time.

\section{Determining Target Depth}

Once a well has been selected for passive monitoring, the target depth to suspend the sonde should be determined. A variety of borehole geophysical depth-profiling methods are available to determine flow into and out of the borehole or well casing, including but not limited to electricalresistance logs, water-quality depth profiles, and flow tests (https://www.usgs.gov/centers/ny-water/science/ borehole-geophysics?qt-science_center_objects $=0 \#$ qtscience_center_objects, and references within). Note the target depth determination process should not be done hastily, as geophysical logging equipment should be slowly lowered down the borehole to minimize disturbance and to let the sensors equilibrate to each new depth before documenting readings. 
Table 2. Well and groundwater pump information for the nine high-frequency groundwater-quality monitoring well stations in the National Water Quality Assessment (NAWQA) Enhanced Trends Network (ETN) Project.

[Land-surface datum (LSD) is a datum plane that is approximatley at land surface at each wellhead. Volume of water needed for standard purge procedure from Wilde (2006a). Abbreviations: ft, foot; gal, gallon; gpm, gallons per minute; ID, identification; in., inch; m, minute]

\begin{tabular}{|c|c|c|c|c|c|c|c|}
\hline $\begin{array}{c}\text { NAWOA ETN } \\
\text { well network and } \\
\text { site ID }\end{array}$ & $\begin{array}{l}\text { Well depth } \\
\text { (ft below } \\
\text { LSD) }\end{array}$ & $\begin{array}{c}\text { Water level } \\
\text { (ft below } \\
\text { LSD) }\end{array}$ & $\begin{array}{l}\text { Casing } \\
\text { diameter } \\
\text { (in.) }\end{array}$ & $\begin{array}{l}\text { Volume of water } \\
\text { needed for standard } \\
\text { purge procedure } \\
\text { (gal) }\end{array}$ & $\begin{array}{l}\text { Pump } \\
\text { rate } \\
\text { (gpm) }\end{array}$ & $\begin{array}{l}\text { Approximate } \\
\text { purge } \\
\text { time } \\
\text { (m) }\end{array}$ & $\begin{array}{l}\text { Groundwater pump } \\
\text { make and model }\end{array}$ \\
\hline $\begin{array}{l}\text { Delaware ETN - } \\
\quad 384637075153201\end{array}$ & 22 & 8 & 2 & 7 & 1.0 & 7 & $\begin{array}{r}\text { ProActive Environmental } \\
\text { Products - Poseidon } 60\end{array}$ \\
\hline $\begin{array}{l}\text { New Mexico ETN - } \\
323733107011002\end{array}$ & 23 & 9 & 2 & 7 & 0.40 & 17 & $\begin{array}{r}\text { ProActive Environmental } \\
\text { Products - Poseidon } 60\end{array}$ \\
\hline $\begin{array}{l}\text { Tennessee ETN - } \\
351111089512501\end{array}$ & 90 & 70 & 4 & 39 & 0.75 & 52 & $\begin{array}{r}\text { ProActive Environmental } \\
\text { Products - Poseidon } 80\end{array}$ \\
\hline $\begin{array}{l}\text { Wisconsin ETN - } \\
443320089212304\end{array}$ & 35 & 25 & 2 & 5 & 1.25 & 4 & $\begin{array}{r}\text { ProActive Environmental } \\
\text { Products - Poseidon } 60\end{array}$ \\
\hline $\begin{array}{l}\text { Wisconsin ETN - } \\
431053090042702\end{array}$ & 50 & 12 & 2 & 18 & 1.50 & 12 & $\begin{array}{r}\text { ProActive Environmental } \\
\text { Products - Poseidon } 60\end{array}$ \\
\hline
\end{tabular}

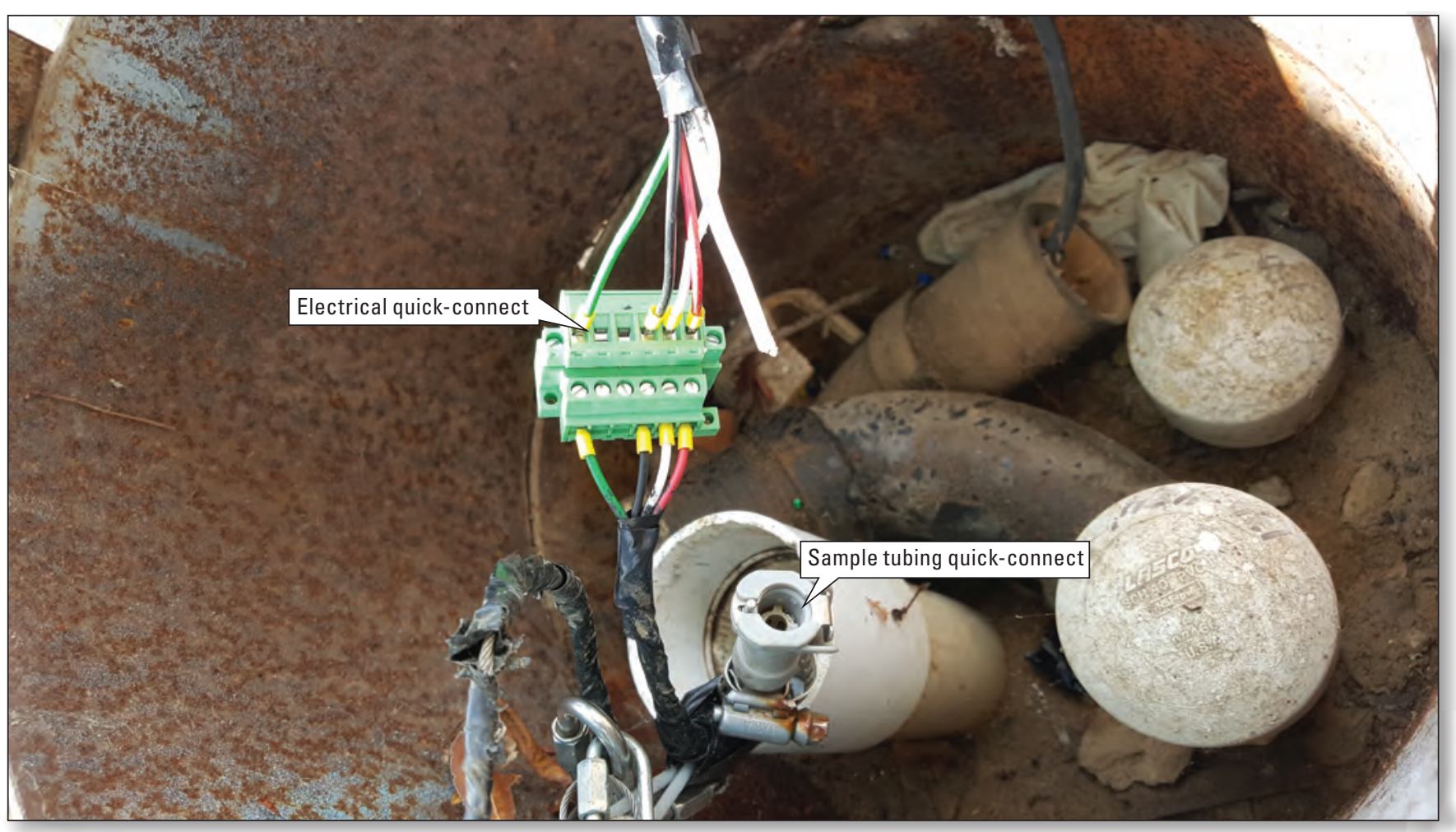

Photograph by Timothy Mathany, U.S. Geological Survey.

Figure 11. Quick-release couplings of the tubing and the electrical wiring at the wellhead of monitoring well station USGS 364200119420003 , Fresno, California. 
Common electrical-resistance logging methods are single-point resistance, spontaneous-potential, and normal resistivity. Single-point resistance logs record the electrical resistance from points within the borehole to an electrical ground at land surface and are useful in the determination of lithology, water quality, and location of fracture zones. Spontaneous-potential logs record potentials or voltages developed between the borehole fluid and the surrounding rock and fluids and can be used in the determination of lithology and water quality. Normal-resistivity logs record the electrical resistivity of the borehole environment and surrounding rocks and water as measured by variably spaced potential electrodes on the logging probe.

Water-quality depth profiles are performed under stable conditions by lowering a calibrated sonde inside the well to measure the field parameters indicative of water-quality changes, such as $\mathrm{SC}$ or temperature.

Flow tests record the direction and rate of horizontal (or vertical) flow rates through the well from within the borehole to determine where representative water is present. These flow tests are most frequently done by impeller flowmeters (used for velocities greater than 5 feet per minute [ft/min]), heat-pulse and electromagnetic flowmeters (used for velocities of less than $0.1 \mathrm{ft} / \mathrm{min}$ ) (Young and Pearson, 1995), or colloidal borescopes (used for velocities less than 1.2 inch per second [in/sec]) (Geotech Environmental Equipment Incorporated, 2019).

\section{Hanging and Securing Sondes}

Servicing, cleaning, and calibrating an in situ deployed sonde is often more time and labor intensive than an ex situ deployed sonde. More time and effort will be spent on site, physically pulling an in situ deployed sonde to and from the well borehole to service and to perform standard maintenance procedures. To ensure successful long-term passive highfrequency data collection at a passively monitored well the sonde should be securely suspended inside the well borehole.

Hanging and securing the sonde inside the well casing and field cable twisting or stretching are challenges to overcome for successful long-term passive high-frequency data collection at a monitoring well. Most field cables have a strain relief support cable for hanging, but because of the repetitive pulling and redeploying of sondes during long duration deployments and cable length needed to reach the DCP at the surface (for real-time transmission), the provided support structure might not be as robust as required to prevent cable failure and the dropping of valuable equipment into the well. Additionally, the weight of hanging the monitoring equipment from long cables can frequently cause cable twisting or stretching (Freeman and others, 2004). These risks compound as deployment depth increases. To securely hang the sonde at depth for long periods of time and to reduce cable twisting or stretching, additional support structures (for example, PVC or plastic-coated cable, stainless-steel wire, or nylon rope secured with U-bolts, aluminum wedge clamps, or stainless-steel connectors) attached to the sonde field cable may be required (Ronen and others, 1987). If using support structures, it is recommended that field personnel secure (or tape) the field cable to the support structure allowing for a little slack between the secured (or taped) sections.

\section{Transmitting Passive Groundwater-Quality Data}

There are two data transmission methods at passively monitored wells real- and non-real-time. If real-time data transmission is prescribed, the station will have field cabling long enough to connect the in situ sonde to the ex situ DCP. At locations where sondes are installed in deep wells or where setting up a full high-frequency groundwater-monitoring station is not feasible, sondes with enabled internal logging are hung from a wire (or similar) in the borehole. These sondes will be pulled from the borehole then connected to a field computer to download the high-frequency groundwaterquality data. When retrieving sondes that are independently logging, timing the retrieval to coincide with a collected data point is helpful in determining your borehole conditions before and after the site visit. The downloaded groundwaterquality data can then be converted into a standard format for upload to the NWIS-TS database to facilitate the initial part of the groundwater-quality records computation process. High frequency groundwater-quality data produced by remotely deployed sondes are an example of non-real-time data and can be treated like real-time data once uploaded to in the NWIS-TS database.

\section{High-Frequency Groundwater-Quality Monitoring Station Maintenance}

The goal for high-frequency monitoring of groundwater quality is to obtain the most representative and complete timeseries data record possible. Frequent and routine site visits are required for the proper inspection and maintenance of the groundwater monitoring stations and associated data collection equipment and thorough record keeping is an integral part of successful site visits. Specific maintenance requirements depend on the station-specific configuration, conditions, and equipment deployed, however, the most important maintenance tasks at all stations are sensor calibrations and the troubleshooting of deployed sondes, sensors, and associated recording/telemetry equipment. Common station maintenance functions at stations equipped with telemetry are as follows:

- Inspection of primary station functions such as telemetry, flow rate, and power.

- Inspection and cleaning of tubing, flow switches, flow cells, external canisters, and manifold (if applicable).

- Inspection of electrical wiring and connections. 
- Checking and charging or swapping of batteries (as necessary) and cleaning solar array.

- Checking the DCP program and downloading of telemetry data (as necessary).

- Cleaning of well site area of anything that could have an adverse effect on field personnel and the water, electrical, or transmission systems such as pests, dust, spider webs, rodent and insect nests, and other station-specific concerns.

Satellite or wireless telemetry can also be used to verify proper daily equipment operation, which helps to identify situations that can require additional site visits, such as, equipment malfunction, electrical service interruption, pump failure, and transmission system failure.

\section{Deployed High-Frequency Groundwater-Quality Sonde Maintenance}

Environmental observations at the 24 high-frequency groundwater-quality wells in the NAWQA ETN Project, and the laboratory evaluation of the water-quality sondes (appendix 1; Mathany and Saraceno, 2019), have shown that calibration drift error is the primary factor affecting the accuracy of high-frequency groundwater-quality measurements, with sensor fouling being a secondary factor. Although the sensor fouling rate for groundwater-quality monitoring stations is often much lower than the fouling rate at surface-water-quality monitoring stations, the effects of fouling must be properly and adequately documented during site visits.

\section{Standard Maintenance Procedure for Deployed High-Frequency Groundwater-Quality Sondes}

The standard maintenance procedure (table 3 ) is used in conjunction with the USGS Site Visit Mobile (SVMobileAQ) program or the USGS High-Frequency Groundwater-Quality Field Form (appendix 2) to establish the data-correction values for the sensor fouling and calibration drift error equations.

All site visit information and deployed and check sonde sensor readings (recorded during multiple steps of the standard maintenance procedure) should be (1) entered directly into the USGS SVMobileAQ program or (2) logged on the USGS High-Frequency Groundwater-Quality Field Form, then transferred to the USGS SVMobileAQ program, onsite
Table 3. Standard maintenance procedure for deployed highfrequency groundwater-quality sondes.

\begin{tabular}{l} 
Standard Maintenance Procedure \\
\hline 1. Initial field parameter readings. \\
\hline a. Record deployed sonde "before cleaning" field readings, times, \\
and sonde conditions. \\
b. Record calibrated check sonde "before cleaning" readings and \\
times. \\
c. Repeat steps 1a, b for multiple wells if sharing deployed sonde \\
(waiting 5 minutes in between wells to flush system). \\
\hline 2. Remove deployed sonde from the installation. \\
\hline 3. Conduct deployed sonde inspection. \\
\hline a. Visually inspect sonde and sensors for signs of wear and physical \\
integrity. \\
b. Clean sensor(s). \\
\hline 4. Return deployed sonde to the installation. \\
\hline a. Record deployed sonde "after cleaning" readings and times. \\
b. Record calibrated check sonde "after cleaning" readings and \\
times. \\
c. Repeat steps 4a, b for multiple wells if sharing deployed sonde \\
(waiting 5 minutes in between wells to flush system). \\
\hline 5. Recalibrate deployed sonde (if prescribed). \\
\hline a. Record pre-calibration check readings. \\
b. Calibrate. \\
c. Record post-calibration check readings. \\
\hline 6. Return deployed sonde to the installation. \\
\hline a. Record deployed sonde "final" readings and times. \\
b. Record calibrated check sonde "final" readings and times. \\
c. Repeat steps 6a, b for multiple wells if sharing deployed sonde \\
\hline
\end{tabular}

(preferred) or offsite (less preferred). The resulting batch files are now ready for upload into the NWIS-TS database for the data correction process (see section, "Applying Data Corrections").

For most groundwater-quality monitoring stations, sondes, and sensors, nearly all operational requirements are fulfilled when using the standard maintenance procedure. Manufacturer instructions should be followed for other types of equipment and sensors. Any adjustments and deviations from the standard maintenance procedure should be well documented in project-specific standard operating procedures, work plans, or USGS Water Science Center QA plans. 


\section{U.S. Geological Survey High-Frequency Groundwater- Quality Field Form}

Electronic USGS High-Frequency Groundwater-Quality Field Forms (or paper, less preferred) are, when accurate, defensible and verifiable documentation of the collection and computation of reliable groundwater-quality monitoring records. The USGS High-Frequency Groundwater-Quality Field Form is also a comprehensive guide for data collection at many groundwater-quality monitoring stations; the electronic version will automatically calculate the well purge time and the calibration threshold (appendix 2). Modifications to the USGS High-Frequency Groundwater-Quality Field Form should be reviewed by the USGS Water Science Center Water-Quality Specialist or other similarly qualified project supervisor to ensure required information is being recorded.

The USGS High-Frequency Groundwater-Quality Field Form includes well purge equation fields (which auto-calculate) and a multiple field-measurement purge log created in accordance with the procedures described in USGS NFM section 6.0 (Wilde, variously dated) and section 4.2.3 (Wilde, 2006a), respectively. These procedures were specifically selected for the set-up procedures at highfrequency groundwater-quality stations as they are the standard criteria used by the USGS for evaluating when extracted groundwater is representative of aquifer conditions, suitable for discrete water-quality sample collection. The well purge equations are used at the initial set-up at all highfrequency monitoring stations to determine the pumping time needed for representative groundwater monitoring to take place. The multiple field-measurement purge log is used to track and document field parameter stability during the initial well purge, and whenever stability tracking is needed. When a single sonde (or sensor) is used to monitor multiple-well stations, purge calculations for each well should be completed.

\section{Use of the Check Sonde}

The check sonde is an additional calibrated waterquality sonde used as the primary reference instrument to verify the deployed sonde readings during the servicing of a high-frequency groundwater water-quality station. These sonde verification steps are accomplished by using the tasks described in the standard maintenance procedure (table 3).

Because of their high cost, a second independent optical nitrate sensor is often not available. Therefore, various quality control procedures are often used to verify, and field validate the optical nitrate sensor performance, and to assess bias. These procedures usually consist of quantifying sensor accuracy in blank water and nitrate standards and using laboratory-determined nitrate concentrations in concurrently collected discrete samples as an additional check of sensor performance (Pellerin and others, 2013). Procedures for calibrating and checking an optical nitrate sensor with nitrate standards and blank water are briefly described in section, "Calibration of Deployed and Check Sondes."

\section{Sonde Readings During the Standard Maintenance Procedure}

Techniques for collecting the data-correction values for the sensor fouling and calibration drift error equations during the standard maintenance procedure will vary slightly depending on if the values are collected using representative groundwater or water from another source. As discussed in the section "Well Purging", representative groundwater is defined as groundwater pumped from the well after sufficient well purging has occurred. Representative groundwater is not required for collecting the data-correction values needed to make sensor fouling and calibration drift error corrections. Accurate data corrections can be made from values collected using water from any source because the data corrections are based on the difference between the "before and after cleaning" and the "before and after calibration" sensor readings, not on the absolute value of the readings. However, if the water used for collecting the data-correction values has a substantially different composition than representative groundwater, a visual assessment of the validity of the applied corrections to the time-series data record in the NWIS-TS database may be more difficult.

Figure 12 shows an example time-series data record for $\mathrm{pH}$ in which the data-correction values were collected in representative groundwater. The sensor readings and the raw and corrected time series are all within a small range in $\mathrm{pH}$ values of 7.95 to 8.20 . The "before and after cleaning" and "after calibration" sensor readings for the deployed sonde, the corresponding check sonde values, and the effect of the corrections on the time series are easy to identify and qualitatively assess visually. If the water used for the collecting of the data-correction values had a substantially different composition, for example, a $\mathrm{pH}$ of 7.00 in this case, the data-correction values for the deployed and check sondes would be displaced from the time series, and the y-axis scale on the graph generated by the Data Correction Toolbox inside NWIS-TS would adjust to a wider range accordingly. It would then be difficult to make a qualitative visual assessment of the validity of the corrections to the time-series data record.

Because changes in water quality in groundwater aquifers commonly occur slowly, and because sensor fouling corrections frequently are minor for sondes deployed in a groundwater environment, the range between the raw and corrected time-series data records generally is small. Using representative groundwater assures that the data-correction values are close to the range of values in the raw and corrected time series, thereby minimizing the y-axis range on the graph. The ability to make qualitative visual assessments of the validity of the data corrections in the NWIS-TS database may be of importance to some projects. However, a specialized setup during the standard maintenance procedure is required to use representative groundwater, which is not feasible to deploy in all situations. 


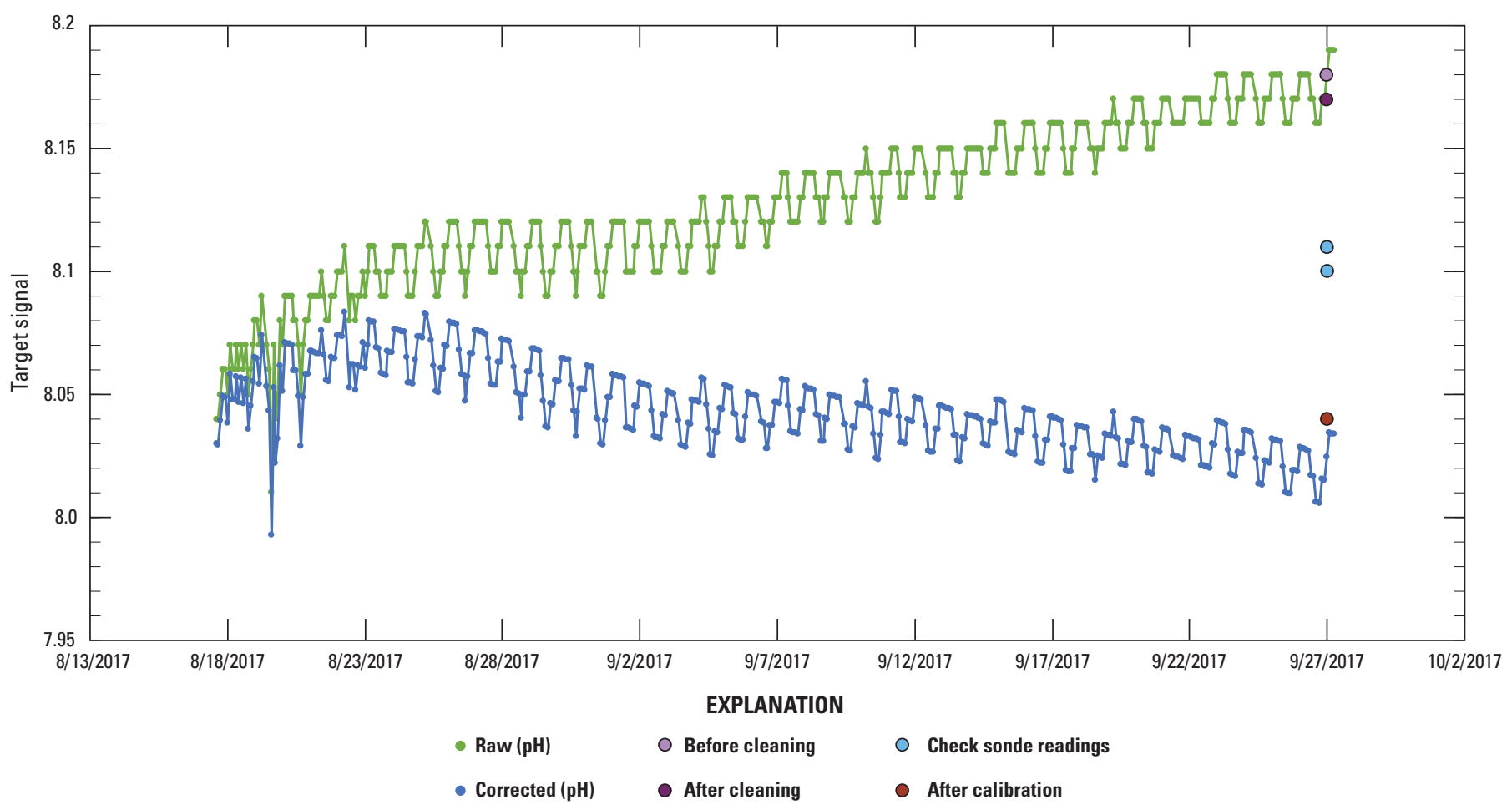

Figure 12. Raw and corrected $\mathrm{pH}$ time-series data and data from end of period site visit at USGS station 364200119420001, August and September 2017.

Figure 13 shows a diagram of the specialized setup for using representative groundwater. The setup consists of a reservoir (for example, a bucket, container, or custom-made vessel) large enough to hold both sondes and tubing to route groundwater from the sampling point on the well discharge to the reservoir. Groundwater flows continuously through the tubing, into the shared reservoir, and overflows. This setup requires active pumping of the well during the period that the data-correction values are collected. For passively monitored wells or stations at which it is not feasible to manage water overflow, for example, the reservoir should just be filled with water from the well or other convenient source. The standard "bucket" method using water from any source is an equally acceptable method for collecting the data-correction values during the standard maintenance procedure.

The first step in the standard maintenance procedure is to record the "before cleaning" sensor readings for each field parameter from the check sonde and the deployed sonde. To accomplish this, carefully remove (trying to minimally disturb the sensors) the deployed sonde from the flow cell (putting on a protective sensor guard, if applicable) and place in the shared reservoir with the check sonde (fig. 13). After both sondes are inside the shared reservoir, representative water is flowing, and the readings are stable, the "before cleaning" readings of the deployed sonde and check sonde are recorded. The deployed sonde is then removed from the shared reservoir for servicing and cleaning. The 24-hour clock time of the deployed sonde "before cleaning" reading becomes the end point for the period of record since the last site visit.
Upon removal from the shared reservoir, inspect the deployed sonde for signs of chemical precipitates, stains, or biological growths that may cause sensor fouling. Record any observations in the appropriate sections of the USGS SVMobileAQ program or the USGS High-Frequency Groundwater-Quality Field Form. A digital photograph can be taken at this (or any) time during the standard maintenance procedure, if applicable, and used as an effective form of documentation to catalog sensor conditions. Clean individual sensors by the procedures outlined in chapter A6 of the USGS NFM (Wilde, variously dated) and the manufacturer specifications; and summarized in section, "Cleaning of Deployed Sondes." Finally, clean the flow cell with a detergent soap (non-phosphate laboratory detergent [for example, LiquiNox] or mild dish soap) and water solution using a soft-bristle brush, then rinse.

After the deployed sonde is cleaned, return it to the shared reservoir and use tubing to refill and overflow with representative groundwater. After the sensors have equilibrated, record the "after cleaning" deployed sonde and check sonde readings. The difference between the deployed sonde "before cleaning" readings and the deployed sonde "after cleaning" readings (accounting for environmental changes determined by use of the check sonde) is a result of sensor (or flow cell) fouling (chemical precipitates, stains, or biological growths). During the record-computation process, the sensor fouling correction is the "set 1" correction (see section, "Applying Data Corrections"). 

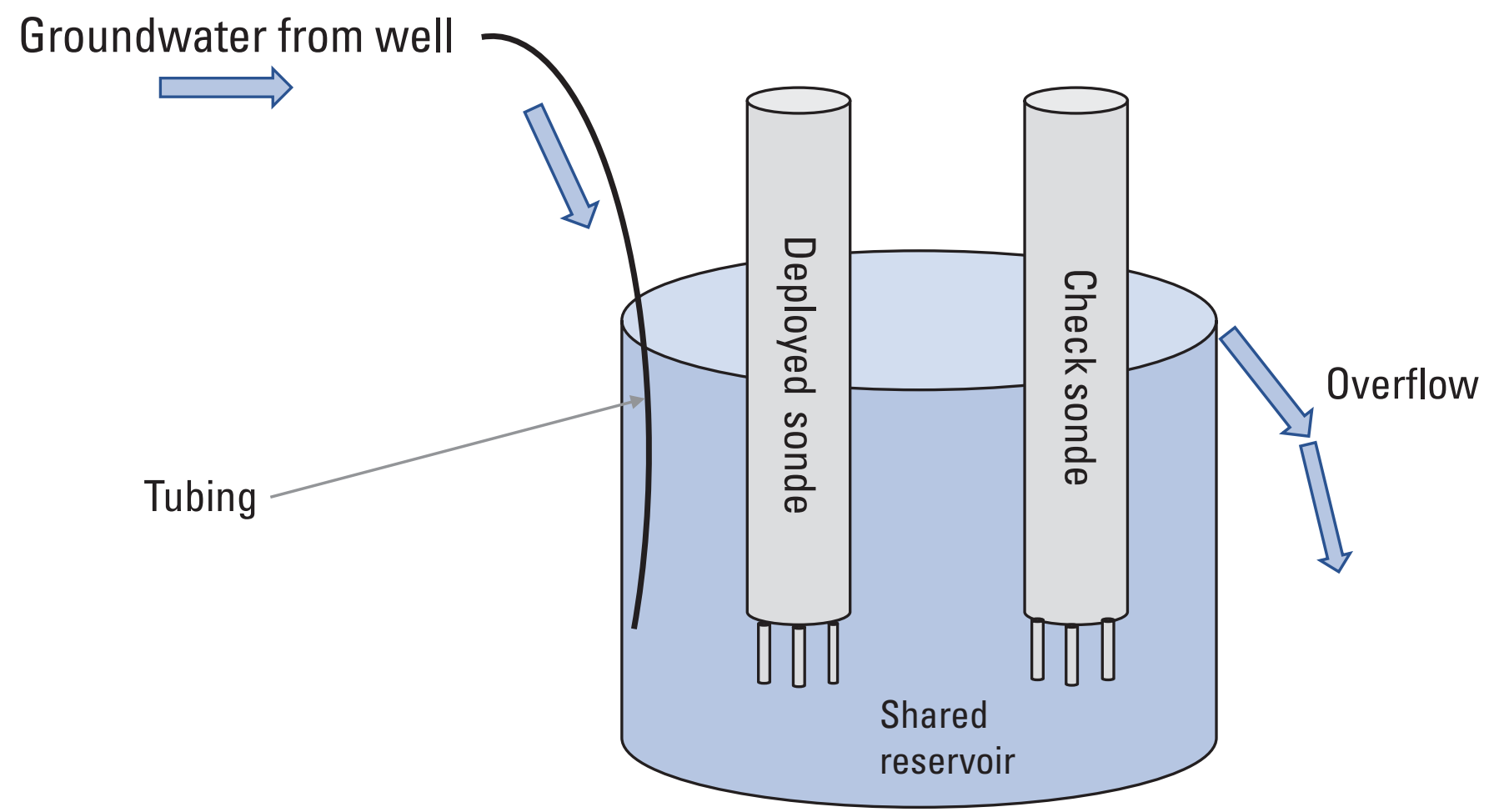

Figure 13. Suggested specialized setup for using representative groundwater during site-visit performance checks of the deployed sonde. (This setup is used in steps 1, 4, and 6 of the standard maintenance procedure; table 3).

After the "after cleaning" readings are recorded, remove the deployed sonde from the shared reservoir, and recalibrate the sonde if warranted (see section, "Calibration of Deployed and Check Sondes"). The difference between the "after cleaning" sensor readings in the calibration standard solutions and the expected reading in these solutions is the result of calibration drift error. During the record-computation process, the calibration drift correction is the "set 2" correction (see section, "Applying Data Corrections").

Return the recalibrated deployed sonde to the shared reservoir and use tubing to refill and with representative groundwater. After the sensors have equilibrated, record the "final" deployed and check sonde readings. The 24-hour clock time of the deployed sonde "final" reading is the start point for the new period of record.

\section{Cleaning of Deployed Sondes}

Manufacturers of most commercially available sensors recommend cleaning with a detergent soap (non-phosphate laboratory detergent or mild dish soap) and water solution using a soft-bristle brush. Film on the sensor that resists removal usually can be removed by soaking the sensor in a stronger detergent and water solution (Ficken and Scott, 1989), a hydrochloric ( $\mathrm{HCl})$ acid solution, or a chlorine bleach solution (for example, YSI Incorporated, 2014; Eureka Environmental Engineering, 2016; RBR Limited, 2016).

Manufacturer recommended cleaning procedures should always be followed carefully for all sondes and sensors. Additionally, chapter A6 of the USGS NFM (Wilde, variously dated) includes detailed instructions for cleaning multiparameter sondes and sensors. During the deployed sonde cleaning, it is important that all electrical ports between the sonde and the sensors are clean and dry, because water in the sensor ports can cause erratic readings (Wagner and others, 2006). Inspect sensor O-rings during every site visit and change as necessary, because worn O-rings are a common cause of water intrusion. 
Water Temperature and Specific Conductance Sensor Cleaning

The USGS NFM sections 6.1 (Temperature; Wilde, 2006b) and 6.3 (Specific Electrical Conductance; U.S. Geological Survey, 2019) recommend thoroughly cleaning temperature/SC sensors with deionized water (DIW) before and after making a discrete measurement (this is sufficient cleaning in most cases). When necessary during sonde cleaning, clean temperature/SC sensors with a non-phosphate laboratory detergent and water solution, then thoroughly rinse with DIW. Carbon and stainless-steel sensors can be cleaned with a soft brush, which is often supplied with the sensor and designed specifically to clean the electrodes, but platinum-coated sensors must never be cleaned with a brush. Under normal circumstances, routine cleaning is all that is required for temperature/SC sensors; however, in the rare cases of contamination or extreme sensor fouling, the manufacturer cleaning instructions should be followed (for example, Hanna Instruments Incorporated, 2014; YSI Incorporated, 2014; Eureka Environmental Engineering, 2016; Hach Company, 2016; RBR Limited, 2016). For instance, some manufacturers recommend soaking SC sensors in vinegar to clean the electrodes should unusual drift be observed during calibration checks (YSI Incorporated, 2014).

\section{pH Electrode Cleaning}

Section 6.4 of the USGS NFM (Ritz and Collins, 2008) recommends that the $\mathrm{pH}$ electrode be kept clean, and the liquid junction (if applicable) should be free flowing to produce accurate $\mathrm{pH}$ values. Never handle the glass bulb with bare fingers; oily film or scratches on the bulb will interfere with the design characteristics of the glass membrane and affect subsequent $\mathrm{pH}$ measurements. The housing holding the electrode or glass bulb should be comprehensively rinsed with DIW before and after each use, which is sufficient cleaning in most cases (Wagner and others, 2006). If needed, clean $\mathrm{pH}$ electrodes and bulbs with a non-phosphate laboratory detergent and water solution. Under normal circumstances, routine cleaning is all that is required for $\mathrm{pH}$ electrodes; however, in the rare cases of contamination or extreme sensor fouling, follow the manufacturer cleaning instructions (for example, Hach Company, 2014; Eureka Environmental Engineering, 2016; RBR Limited, 2016; Hanna Instruments Incorporated, 2017; YSI Incorporated, 2017).

\section{Optical Dissolved Oxygen Sensor Cleaning}

Routine cleaning of optical DO sensors involves inspecting the optical surface at the tip of the sensor and, if necessary, wiping it clean with a non-abrasive, lint-free cloth, soft brush, detergent soap, or low-pressure water rinse (for example, YSI Incorporated, 2014; PASCO Scientific, 2015; Insite Instrumentation Group Incorporated, 2017). Section 6.2 of the USGS NFM (Rounds and others, 2013) also suggests checking the deployment history of the optical DO sensor module, and depending on the instrument, sensor modules should be replaced annually. Amperometric DO sensors are not discussed here, but are discussed in Wagner and others (2006); references therein offer more information on these types of sensors.

\section{Optical Nitrate Sensor Cleaning}

Operation and maintenance of optical nitrate sensors should follow manufacturer recommendations. Regular instrument performance qualifications should be regularly carried out as outlined in Pellerin and others (2013; table 5). Optical nitrate sensors should be cleaned during every site visit, and sensor fouling should be quantified by using the "before-cleaning" and "after-cleaning" readings of paired sensors. If a check sensor is not available for paired sensor readings, then the deployed optical nitrate sensor reading of a known nitrate standard can be used to determine sensor fouling. This approach is acceptable so long as disturbance to the measurement system is minimized prior to the collection of a "before-cleaning" reading. Optical nitrate sensors should be first rinsed with DIW to remove any particulate matter and to prevent scratching of the optical windows (Pellerin and others, 2013). The optical windows can then be lightly scrubbed with a soft brush, or cotton-tipped applicator, followed by lint-free wipes and a final wiping with lens paper. Diluted $\mathrm{HCl}$ acid may be used to remove staining from organic matter or iron precipitates (Etheridge and others, 2013). If fouling rates are severe, then an anti-fouling device (such as a mechanical wiper or compressed air) should be fitted according to manufacturer recommendations.

\section{Calibration of Deployed and Check Sondes}

Given the potential for small errors to have a disproportionately adverse effect on high-frequency groundwater-quality records, it is advisable that waterquality data be extremely stable during the sensor fouling and calibration check steps of the standard maintenance procedure (table 3). To perform these steps correctly, it is critical that both the deployed and check sondes are calibrated to a high degree with fresh calibration standards (or buffers). Expired standards should never be used for calibrations. Furthermore, to ensure calibration drift is not interpreted incorrectly as real groundwater quality changes, personnel are strongly advised to adopt as consistent practice to (1) recalibrate a groundwaterquality sensor if the measured value in a calibration standard (or buffer) is outside of the calibration threshold and (2) apply the calibration drift error correction to the previous period of record if a calibration occurs (see section, "Applying Data Corrections"). 
The calibration threshold is used for $\mathrm{SC}, \mathrm{pH}$, and $\mathrm{DO}$ sensor calibrations and is determined by taking the expected temperature-compensated standard (or buffer) value, and then adding and subtracting the manufacturer's stated sensor precision, described by the following equation and represented by fillable fields on the USGS High-Frequency GroundwaterQuality Field Form that auto-calculates the threshold (appendix 2):

$$
C T=(E V) \pm(P)
$$

where

$$
\begin{aligned}
& C T \text { is calibration threshold, in units of the } \\
& \text { calibration standard (or buffer), } \\
& E V \quad \text { is expected temperature-compensated } \\
& \text { standard (or buffer) value, and } \\
& P \quad \text { is the manufacturer's stated sensor precision, } \\
& \text { in units identical to those of the CT. }
\end{aligned}
$$

For example, pH 7 buffer at 20 degrees Celsius $\left({ }^{\circ} \mathrm{C}\right)$ has an expected value of 7.02, and if a generic $\mathrm{pH}$ sensor has a stated precision of 0.04 units, then the calibration threshold is $6.98-7.06 \mathrm{pH}$ units. If a sensor reading is outside of the calibration threshold, then a recalibration is prescribed.

All sensor calibrations should be recorded electronically in the USGS SVMobileAQ program or on the USGS High-Frequency Groundwater-Quality Field Form with all measurements and documentation about sensor replacements, instrument upgrades, and any other circumstances or conditions that could have affected instrument readings.

\section{Specific Conductance Sensor Calibration}

The USGS reports SC in microsiemens per centimeter $(\mu \mathrm{S} / \mathrm{cm})$ compensated to $25^{\circ} \mathrm{C}$. Calibration guidelines for specific electrical conductivity sensors for discrete waterquality sampling presented in section 6.3 of the USGS NFM (U.S. Geological Survey, 2019) have been modified in this report to more accurately reflect the data-quality objectives present at high-frequency groundwater-quality monitoring stations and manufacturer's specifications (for example, YSI Incorporated, 2014).

High-frequency groundwater-quality monitoring applications commonly involve two considerations outside of the scope of current USGS NFM guidance (U.S. Geological Survey, 2019). These include (1) accommodating conditions for field calibration of SC sensors and (2) anticipating a wider range of conditions common in long-term groundwater monitoring installations. Because field calibrations are used, and wide ranges of $\mathrm{SC}$ conditions can exist at any given high-frequency monitoring installation, it is important to use $1,000 \mu \mathrm{S} / \mathrm{cm}$ at $25^{\circ} \mathrm{C}$ standard (or higher) in the one-point instrument calibration to limit potential for biasing calibration standard and to ensure the sensor was calibrated to a value greater than the highest expected range of conditions. To ensure linearity below $1,000 \mu \mathrm{S} / \mathrm{cm}$ at $25^{\circ} \mathrm{C}$, check the sensor in at least one additional standard of known conductance (for example, $500 \mu \mathrm{S} / \mathrm{cm}$ at $25^{\circ} \mathrm{C}$ ). Subsequent checks in lower valued standards are also used to encompass the expected range of values for the anticipated groundwater conditions.

\section{pH Electrode Calibration}

Calibrate the $\mathrm{pH}$ electrode with two or three standard buffer solutions in accordance with section 6.4.3 of the USGS NFM (Ritz and Collins, 2008). At most stations, use the $\mathrm{pH} 7$ buffer to establish the null point, and the $\mathrm{pH} 4$ and $\mathrm{pH} 10$ buffers to establish the slope of the calibration line at the temperature of the solution. If station history indicates that $\mathrm{pH}$ values are never greater than 7, use the $\mathrm{pH} 4$ and $\mathrm{pH} 7$ for the calibration. If history indicates that $\mathrm{pH}$ values are never less than 7, use the $\mathrm{pH} 7$ and $\mathrm{pH} 10$ buffers for the calibration. Calibrations (if prescribed) are done during the site visit with buffers that have been allowed to equilibrate to the approximate temperature of the groundwater being monitored. Proper calibration of $\mathrm{pH}$ sensors does not ensure accurate $\mathrm{pH}$ measurements for low SC waters. Consult section 6.4.3.B of the USGS NFM for the recommended procedure when the measured SC of the groundwater is less than $100 \mu \mathrm{S} / \mathrm{cm}$ at $25^{\circ} \mathrm{C}$ (Ritz and Collins, 2008).

\section{Optical Dissolved Oxygen Sensor Calibration}

Optical DO sensors are the recommended DO sensor type for high-frequency groundwater-quality measurements and are available in single-parameter DO meters or multiparameter sondes, each of which can be deployed for longterm, unattended, high-frequency, real-time measurements. Calibrate optical DO sensors to 100-percent DO saturation at every site visit (if prescribed) and check annually with a zero DO (0.0 milligrams per liter; $\mathrm{mg} / \mathrm{L}$ ) solution to provide an indication of sensor-response linearity in accordance with section 6.2 of the USGS NFM (Rounds and others, 2013).

Calibration of an optical DO sensor at 100-percent oxygen saturation is made by adjusting the sensor reading for air saturated with water vapor (in flow cell) or air-saturated water (with a bubbler in a bucket) to a value obtained from a DO solubility table (http://water.usgs.gov/software/ dotables.html; Benson and Krause, 1980, 1984). The DO solubility is based on the water temperature, the ambient barometric pressure, and salinity. Use a National Institute of Standards and Technology- (NIST) traceable pocket altimeter or the barometer installed on most sondes to measure ambient barometric pressure to the nearest 0.04 inch ( 1 millimeter $[\mathrm{mm}]$ ) of mercury; a SC sensor can be used to approximate salinity. The barometer on a handheld unit should be checked prior to each site visit with a NIST-traceable barometer and the NIST-traceable barometer should be re-certified annually according to manufacturer recommendations. Records of NIST-traceable barometer re-certification should be stored in an archived electronic logbook. 
The accuracy of an optical DO sensor at $0.0 \mathrm{mg} / \mathrm{L}$ should be verified by measuring the $\mathrm{DO}$ of a fresh solution of sodium sulfite, or nitrogen purged DI water, as described in section 6.2 of the USGS NFM (Rounds and others, 2013). For groundwater locations with anoxic conditions (for example, DO less than $1.5 \mathrm{mg} / \mathrm{L}$ ), zero DO checks and calibrations should be done more frequently, such as during every site visit. Because zero DO checks and calibrations in sodium sulfite solutions are sensitive to large shifts in temperature, such as those encountered in the field, zero DO checks and calibrations should be done in a laboratory setting, such as a mobile laboratory or vehicle.

\section{Water Temperature Sensor Calibration}

Complete a five-point temperature calibration check prior to installation of a temperature sensor (thermistor, transducer, or sonde) in accordance with section 6.1.2 of the USGS NFM (Wilde, 2006b). This calibration check will be done against a calibrated temperature thermistor (thermometer, sensor, or transducer) that has either (1) been certified by the NIST, (2) been certified by the manufacturer as NIST-traceable, or (3) passed the same five-point temperature calibration check as the deployed sensor (U.S. Geological Survey, 2012; hereinafter referred to as NIST-traceable thermistor). All temperature sensors (thermistors, transducers, or sondes) should be marked with the date of certification/calibration. Document the annual temperature checks and calibration data in an instrument logbook or archived electronic logbook.

Three times a year, check the performance of the deployed temperature sensor with a two-point calibration check and once a year with a five-point calibration check by way of a side-by-side comparison against the NISTtraceable thermistor. To accomplish this, remove the deployed temperature sensor from the well (or flow cell) and perform the side-by-side check against the NIST-traceable thermistor in the matrix water of your choosing. If removing the deployed temperature sensor is impractical, in situ checks may be performed. The in situ temperature check is accomplished by lowering the NIST-traceable thermistor into the well to the depth of the deployed sensor so that they are side-byside. Allow the NIST-traceable thermistor to equilibrate for 20 minutes to reduce any temperature change owing to thermal mass effects and record the temperature of the deployed and check temperature sensors.

No matter the calibration or performance check method, compare the temperature readings of the deployed and the NIST-traceable thermistor. If the readings are within the $\pm 0.2{ }^{\circ} \mathrm{C}$ accuracy specifications (Wagner and others, 2006), then no additional action is needed. If the deployed temperature sensor drifts beyond accuracy specifications it should be replaced, and the data excluded from publication in the NWIS-TS database (U.S. Geological Survey, 2012).

\section{Optical Nitrate Sensor Calibration}

Calibration and documentation guidance for optical nitrate sensors are detailed in Pellerin and others (2013). Depending on the sensor model, the sensor may be calibrated or only checked to verify accuracy. After cleaning, first remove the nitrate sensor and do the pre-calibration baseline check (table 3, step 5a) using reagent grade inorganic blank water (Pellerin and others, 2013). Optical nitrate sensors might not be able to be field calibrated, so consult manufacturer specification and guidelines before continuing. If the sensor can be field calibrated, use one standard (for example, $1 \mathrm{mg} / \mathrm{L}$ nitrate as nitrogen $\left[\mathrm{NO}_{3}\right.$ as $\left.\mathrm{N}\right]$ ) with known value near expected concentrations, and check the calibration using another standard of known quantity (for example, $5 \mathrm{mg} / \mathrm{L} \mathrm{NO}_{3}$ as $\mathrm{N}$ ). Before deployment, the optical nitrate sensor readings should be within the manufacturer specification of the standard value (Pellerin and others, 2013). Calibrations (if prescribed) are done at the site visit with calibration standard solutions that have been allowed to equilibrate to the approximate temperature of the groundwater being monitored. Stock nitrate standards at concentration levels of 1, 10, 100, and $1,000 \mathrm{mg} / \mathrm{L} \mathrm{NO}_{3}$ as $\mathrm{N}$ may be diluted to achieve the desired concentrations to encompass the expected water chemistry range of each monitoring station. In addition, nitrate check standards may be made with American Chemical Society reagent grade chemicals (for example, Potassium nitrate, 99+ percent, Chemical Abstracts Service \#7757-79-1) spiked into inorganic-grade blank water within 48 hours of use, and stored in darkness at $4{ }^{\circ} \mathrm{C}$.

If the optical nitrate sensor cannot be field calibrated or calibration standards are not available, concurrent discrete samples can also be used to check sensor accuracy and asses bias. Collect discrete nitrate samples from each well according to protocols set forth in the USGS NFM 5.2.1A (Radtke and others, 2002) and send to a laboratory for analysis using a separate UV nitrate sensor or traditional wet-chemical methods (Pellerin and others, 2013). Load all discrete sample records and the accompanying field data into the USGS NWIS database and stored under USGS parameter code 00631 (nitrate plus nitrite as nitrogen, in $\mathrm{mg} / \mathrm{L}$ ) for future availability and data analysis. Determine the need for bias corrections based on the comparison of in situ nitrate-sensor data and the concurrent discrete nitrate sample data in accordance with the procedures described in Pellerin and others (2013).

\section{Troubleshooting Water-Quality Sondes}

The water-quality sonde troubleshooting guide used in this report is from Wagner and others (2006) and Pellerin and others (2013) but modified for situations unique to groundwater-quality sensors. Some of the common problems encountered in the field when servicing groundwater-quality sensors, as well as solutions, are listed in f. 
Table 4. Troubleshooting guide for problems with groundwater-quality sensors.

[Modified from Wagner and others, 2006, and Pellerin and others, 2013. Abbreviation: DO, dissolved oxygen]

\begin{tabular}{|c|c|c|}
\hline Symptom & Possible problem & Likely solution \\
\hline \multicolumn{3}{|c|}{ Water temperature } \\
\hline $\begin{array}{l}\text { Thermistor does not read } \\
\text { accurately or is slow to } \\
\text { stabilize. }\end{array}$ & Dirty sensor. & $\begin{array}{l}\text { Clean sensor. } \\
\text { Increase flow rate of water system. }\end{array}$ \\
\hline Erratic readings. & $\begin{array}{l}\text { Poor connections between bulkhead and sensor. } \\
\text { Bubbles. }\end{array}$ & $\begin{array}{l}\text { Clean and tighten connections. } \\
\text { Increase flow rate of water system. Thrust sonde up } \\
\text { and down and tap flow cell gently to expel air. }\end{array}$ \\
\hline Readings off scale or error codes. & Failure in electronics. & $\begin{array}{l}\text { Replace sensor. } \\
\text { Replace sonde. }\end{array}$ \\
\hline \multicolumn{3}{|c|}{ Specific conductance } \\
\hline
\end{tabular}

\begin{tabular}{ll}
\hline Sensor will not calibrate. & $\begin{array}{l}\text { Calibration standards may be old or } \\
\text { contaminated. } \\
\text { Electrodes dirty. } \\
\text { Weak batteries. }\end{array}$ \\
& Poor connections between bulkhead and sensor. \\
& Bubbles or air trapped in flow-cell chamber.
\end{tabular}

Use fresh standard solutions, check lot numbers.

Clean with dilute soap solution.

Replace batteries.

Electrodes dirty.

Clean and tighten connections.

Thrust sonde up and down and tap flow-cell chamber gently to expel air.

Increase flow rate of water system.

Sensor requires frequent

Broken or internally disconnected cables. calibration.

Defective sensor.

Replace cables.

Replace sensor.

Replace sonde.

\begin{tabular}{|c|c|c|}
\hline & & \\
\hline \multicolumn{3}{|c|}{$\mathrm{pH}$} \\
\hline Slow response time. & $\begin{array}{l}\text { Dirty sensor bulb. } \\
\text { Water is cold or of low ionic strength. }\end{array}$ & $\begin{array}{l}\text { Clean bulb (carefully). } \\
\text { Be patient, things will stabilize. }\end{array}$ \\
\hline $\begin{array}{l}\text { Sensor requires frequent } \\
\text { calibration. }\end{array}$ & $\begin{array}{l}\text { Broken or internally disconnected cables. } \\
\text { Defective sensor. }\end{array}$ & $\begin{array}{l}\text { Replace cables. } \\
\text { Replace sensor. } \\
\text { Replace sonde. }\end{array}$ \\
\hline $\begin{array}{l}\text { Sensor drift or excessive time for } \\
\text { sensor to stabilize. }\end{array}$ & $\begin{array}{l}\text { Temperature compensator has not equilibrated } \\
\text { with the groundwater. } \\
\text { Fouled sensor. }\end{array}$ & $\begin{array}{l}\text { Wait for temperature equilibration. } \\
\text { Clean sensor. } \\
\text { Recondition sensor. }\end{array}$ \\
\hline Erratic readings. & $\begin{array}{l}\text { Poor connections between bulkhead and sensor. } \\
\text { Fouled sensor. } \\
\text { Bubbles. }\end{array}$ & $\begin{array}{l}\text { Clean and tighten connections. } \\
\text { Clean cap. } \\
\text { Replace cap. } \\
\text { Thrust sonde up and down and tap flow cell gently } \\
\quad \text { to expel air. } \\
\text { Invert flow cell. } \\
\text { Add debubbler to water system. } \\
\text { Increase flow rate of water system. }\end{array}$ \\
\hline
\end{tabular}


Table 4. Troubleshooting guide for problems with groundwater-quality sensors. - Continued

[Modified from Wagner and others, 2006, and Pellerin and others, 2013. Abbreviation: DO, dissolved oxygen]

\begin{tabular}{|c|c|c|}
\hline Symptom & Possible problem & Likely solution \\
\hline \multicolumn{3}{|c|}{ Dissolved oxygen-Continued } \\
\hline $\begin{array}{l}\text { Sensor requires frequent } \\
\text { calibration. }\end{array}$ & $\begin{array}{l}\text { Broken or internally disconnected cables. } \\
\text { Defective sensor. }\end{array}$ & $\begin{array}{l}\text { Replace cables. } \\
\text { Replace sensor. } \\
\text { Replace sonde. }\end{array}$ \\
\hline $\begin{array}{l}\text { Sensor will not pass the zero-DO } \\
\text { check. }\end{array}$ & $\begin{array}{l}\text { Zero-DO solution contains oxygen. } \\
\text { Zero-DO solution is old. }\end{array}$ & $\begin{array}{l}\text { Add additional sodium sulfite to zero-DO solution. } \\
\text { Mix a fresh zero-DO solution. }\end{array}$ \\
\hline \multicolumn{3}{|c|}{ Nitrate } \\
\hline $\begin{array}{l}\text { Sensor does not report nitrate } \\
\text { concentration. }\end{array}$ & Optical path is dirty or blocked. & $\begin{array}{l}\text { Check and clean windows. } \\
\text { Check flow path chamber is on correctly. }\end{array}$ \\
\hline Sensor will not calibrate. & $\begin{array}{l}\text { Calibration standards may be old or } \\
\text { contaminated. }\end{array}$ & Use fresh standard solutions, check lot numbers. \\
\hline Erratic readings. & Bubbles in flow path. & $\begin{array}{l}\text { Invert flow path. } \\
\text { Increase flow rate of water system. } \\
\text { Add debubbler to water system. }\end{array}$ \\
\hline
\end{tabular}

Satellite telemetry data can often warn the field and office personnel of impending sensor failures by providing sensor diagnostic information from remote locations. For example, $\mathrm{pH}$ millivolt readings, transmitted in real-time and stored internally (on the sonde), can be used by personnel as a diagnostic for troubleshooting $\mathrm{pH}$ readings. Anomalously high or low $\mathrm{pH}$ millivolt readings can often indicate that there is a failing $\mathrm{pH}$ sensor that should be replaced, during the next site visit at the latest. Important diagnostics for optical nitrate sensors include low light levels (counts) or high internal humidity (typically greater than 50 percent). Anomalous readings in either of these indicators typically suggest a problem with the light source or detector, which requires a sensor repair or complete replacement.

Optical nitrate sensor accuracy is susceptible to matrix interference by organic matter, sensor fouling, and bromide (Pellerin and others, 2013). The effects and potential solutions are listed in table 5. However, sediment, organic matter, and biological loading in groundwater are typically low, so the detrimental effects of these substances and of biological fouling are expected be minimal in most cases. In contrast, groundwater can have elevated levels of salts, including bromide, and care should be taken to mitigate this interference, either by quantifying the effect by using laboratory samples, or by applying an onboard temperature-salinity correction, if available (table 5; Sakamoto and others, 2009; Pellerin and others, 2013).

As with nitrate concentration data, optical nitrate sensor metadata are often available and may aid in the interpretation of the time-series data record and sensor troubleshooting (table 6). Activate optical nitrate sensor metadata logging in the routine setup of any nitrate sensor in the NWIS-TS database. For example, metadata related to sensor light intensity, such as the light and dark counts, and lamp time, may be tracked to provide information about sensor fouling, lamp degradation, or an impending lamp failure. In addition, metadata relating to the quality of the light spectrum used for the nitrate calculation, such as the root mean square error (RMSE) of dark measurements, may be used to qualify the nitrate concentration data. 
Table 5. Optical nitrate sensor factors and impacts affecting accuracy and solutions.

[cDOM, chromophoric dissolved organic matter; fDOM, fluorescent dissolved organic matter; TCSS, temperature compensated, salinity subtracted]

\begin{tabular}{|c|c|c|}
\hline Matrix constituent & Potential impact & Solutions \\
\hline $\begin{array}{l}\text { Elevated cDOM } \\
\text { (chromophoric dissolved } \\
\text { organic matter). }\end{array}$ & $\begin{array}{l}\text { High bias to calculated nitrate concentrations as } \\
\text { it absorbs light more closely to that of nitrate } \\
\text { and } \\
\text { Reduced accuracy and precision as wavelength } \\
\text { channels are increasingly absorbed, leading to } \\
\text { exclusion from processing. }\end{array}$ & $\begin{array}{l}\text { Adjustments of advanced settings (for example, } \\
\text { absorbance thresholds or integration time) which can } \\
\text { result in decreased accuracy and precision. } \\
\text { Development and maintenance of bias corrections or } \\
\text { ratings. } \\
\text { Additional chemical analysis of discrete samples and } \\
\text { real-time data collection of additional parameters (for } \\
\text { example, fDOM) to identify and quantify interfering } \\
\text { species. }\end{array}$ \\
\hline $\begin{array}{l}\text { Elevated Bromide } \\
\text { (salinity). }\end{array}$ & $\begin{array}{l}\text { High bias and } \\
\text { Imprecision of calculated nitrate values due to } \\
\text { compensation errors in optically fitting the } \\
\text { temperature-dependent absorption of bromide. }\end{array}$ & $\begin{array}{l}\text { Specific manufacturer calibration for salt water needed; or } \\
\text { Collection of independent temperature and salinity data } \\
\text { to calculate nitrate concentrations using the TCSS } \\
\text { algorithm }{ }^{1} \text {; required for brackish or seawater sites. }\end{array}$ \\
\hline
\end{tabular}

${ }^{1}$ Guidance from Sakamoto and others, 2009.

Table 6. Useful nitrate metadata with expected ranges for optical sensor troubleshooting and data qualification.

[AU, absorbance units; mg N/L, nitrite plus nitrate, as milligrams of nitrogen per liter; mm, millimeter; nm, nanometer; NWIS-TS, National Water Information System-Time Series database; RMSE, root mean square error; $\%$, percent; ${ }^{\circ} \mathrm{C}$, degrees Celsius]

\begin{tabular}{ll}
\hline \multicolumn{1}{c}{$\begin{array}{c}\text { Nitrate metadata parameter } \\
\text { (label) }\end{array}$} & \multicolumn{1}{c}{$\begin{array}{c}\text { Expected } \\
\text { range }\end{array}$} \\
\hline Nitrate concentration (various) & $0-42 \mathrm{mg} \mathrm{N} / \mathrm{L}(56 \mathrm{mg} \mathrm{N} / \mathrm{L}$ for $5 \mathrm{~mm}$ path). \\
Light measurement (Nitrate.Light.Count) & Typically 3,000-30,000; ideally greater than 5,000 counts. \\
Dark measurement (Nitrate.Dark.Count) & Typically $500-1,000$ counts. \\
Fit RMSE (Nitrate.Fitting.Param) & Recommended accepted upper limit of $0.01 \mathrm{mg} \mathrm{N} / \mathrm{L}$. \\
Absorbance, $254 \mathrm{~nm}($ Nitrate.254) and & Less than $1.3 \mathrm{AU}$ by default; higher AU values indicative of matrix interference, fouling, or \\
$350 \mathrm{~nm}$ (Nitrate.350) & lamp related issues. \\
Relative humidity (Nitrate.humid) & Greater than $50 \%$ is problematic; greater than $90 \%$ is indicative of flooding of the housing. \\
Lamp time (sec) & Lamps rated to 1,000 hours $(3,600,000$ seconds). \\
Internal temperature $\left({ }^{\circ} \mathrm{C}\right)$ & $-2{ }^{\circ} \mathrm{C}$ to $\left.35^{\circ} \mathrm{C} \mathrm{(default} \mathrm{lamp} \mathrm{shutoff} \mathrm{at} 35^{\circ} \mathrm{C}\right)$. \\
\hline
\end{tabular}




\section{Record Computation}

The record-computation process validates high-frequency groundwater-quality data and documents its quality. The processing of high-frequency groundwater-quality monitoring records will be completed in a timely manner according to the USGS (U.S. Geological Survey, 2010; 2017a). USGS Water Science Center policies, groundwater QA plans, and projectspecific QA plans typically establish data-quality requirements and procedures that also will be followed. The field personnel who service the high-frequency groundwater-quality sonde typically compute the high-frequency groundwater-quality record for the completed monitoring period, update the station analysis in the USGS Site Information Management System (SIMS), update the station description (when necessary) in the USGS Records Management System (RMS; click the "Your RMS WSC Home" link), and finalize the time-series data record for approval.

\section{Record-Computation Procedures}

Record-computation procedures include eight steps: (1) set up a new high-frequency groundwater-quality monitoring station in the NWIS-TS database, (2) evaluate initial data, (3) pre-process corrections, (4) apply data corrections, (5) finalize data evaluation, (6) finalize time-series data record, (7) approve time-series data records, and (8) audit time-series data records.

\section{Reporting Units and Parameter and Method Codes}

High-frequency groundwater-quality monitoring data will be stored in the NWIS-TS database in the form of instantaneous values. An instantaneous value is a single high-frequency groundwater-quality measurement recorded during a time interval (for example, every 15 minutes). Raw (uncorrected) instantaneous values (RIVs) are the raw highfrequency groundwater-quality measurements recorded during the period of record. Corrected instantaneous values (CIVs) are the edited values after the field or office personnel applies pre-processing corrections and appropriate data corrections (set 1 or set 2).

High-frequency groundwater-quality monitoring data can also be stored in the NWIS-TS database in the form of discrete values. Data from all makes and models of each type of sensor (water temperature, $\mathrm{SC}, \mathrm{pH}$, and $\mathrm{DO}$ ) that use similar technology in making measurements can be stored under the appropriate parameter and method codes (table 7). Optical nitrate sensor data are stored and reported using the parameter code 99133 (nitrate plus nitrite, water, in situ, milligrams per liter as nitrogen) and method codes and measurement reporting units that are specific to the instrument type used (table 7).

\section{Setting Up a New High-Frequency Groundwater- Quality Monitoring Station in the NWIS-Time Series Database}

High-frequency groundwater-quality monitoring station records should be established in the NWIS-TS database, as part of standard USGS procedures for groundwater site establishment (Cunningham and Schalk, 2011). Additionally, the QA plans for groundwater activities, prepared by the USGS Water Science Center, are followed to establish each groundwater station. Once the groundwater station is established in the NWIS-TS database, the field and office personnel should adjust record computation settings during the groundwater-quality station set-up process in the NWIS-TS database. These settings include time-series thresholds, openended outlier trim corrections, and daily values.

Time-series thresholds are QA conditions placed on the high-frequency groundwater-quality data series; for example, if field parameter values are reported at greater than or less than the established threshold, the data are automatically suppressed from provisional release until reviewed. Select time-series threshold values based on historical readings at the station and update (if needed) once high-frequency data collection begins.

Table 7. Parameter codes and reporting units for measured field parameters and nitrate at groundwater-quality monitoring stations.

[mg/L, milligrams per liter; mm, millimeter; $\mu \mathrm{S} / \mathrm{cm}$, microsiemens per centimeter at $25^{\circ} \mathrm{C} ;{ }^{\circ} \mathrm{C}$, degrees Celsius ]

\begin{tabular}{lclcl}
\hline \multicolumn{1}{c}{ Field parameter } & Parameter code & \multicolumn{1}{c}{ Method code } & Reporting unit & \multicolumn{1}{c}{ Reporting convention } \\
\hline Temperature & 00010 & THM01 & ${ }^{\circ} \mathrm{C}$ & To nearest $0.1^{\circ} \mathrm{C}$. \\
Specific conductance & 00095 & SC001 & $\mu \mathrm{S} / \mathrm{cm}$ & Three significant figures, whole numbers only. \\
pH & 00400 & PROBE & standard pH unit & To nearest 0.1 standard $\mathrm{pH}$ unit. \\
Dissolved oxygen & 00300 & LUMIN & $\mathrm{mg} / \mathrm{L}$ & To nearest $0.1 \mathrm{mg} / \mathrm{L}$. \\
Nitrate & 99133 & UV012 through UV018 & $\mathrm{mg} / \mathrm{L}^{1}$ & To nearest $0.01 \mathrm{mg} / \mathrm{L}^{1}$. \\
\hline
\end{tabular}

${ }^{1}$ Method code, reporting unit, and reporting convention is specific to the instrument type used. 
Open-ended outlier trim corrections are QA conditions placed on the high-frequency groundwater-quality data series to remove rapidly increasing and decreasing waterquality data automatically. The open-ended outlier trim correction removes erroneous spikes that are within the upper and lower time-series thresholds by using a rate-of-change deviation value. The open-ended outlier trim correction setup is nuanced; the trick is to set the deviation value large enough to remove the erroneous data but leave the valid data alone. Open-ended outlier trim should only be used to remove large, rapidly changing, obvious data spikes. Small data spikes should be removed manually (de-spiked) from the period of record in NWIS-TS by using the "Outlier Trim Correction" in the Data Correction Toolbox (see section, "Pre-Processing Corrections").

Daily values settings define the summary statistic used to describe the water-quality parameter values that are deemed most representative for use in summarizing measurements for that day in the NWIS-TS database. The daily value for each water-quality parameter is commonly defined by the mean or median of all the measurements for that day.

An important step during the setup of a new highfrequency groundwater-quality monitoring station is to determine if the daily value statistic is even a necessary part of the record-computation workflow for the station being observed. For stations located at high-capacity supply wells, which monitor groundwater quality 24 hours a day, 7 days a week, the daily value might not be very important to calculate, since representative water-quality values are most often always present. For stations located at domestic supply or monitoring wells, the daily value might be more important to calculate since pumping is often sporadic, prescribed for only at certain times of the day, or only when a certain amount of water is demanded by the system.

If the daily value statistic is deemed as appropriate for the scientific objectives at a specific groundwater-quality monitoring station, select the daily value that is most appropriate for the monitoring objectives. The procedures for generating, reporting, and reviewing daily values are outlined in Wagner and others (2006).

\section{Evaluating Initial Data}

Implement a daily process for data evaluation to verify the accurate transfer of raw field data (deployed sonde readings) to the NWIS-TS database, and evaluate, identify, and exclude erroneous groundwater-quality data from the period of record. Event-related effects on the data series are important and can be easily identified through historical measurements, field experience, and first-hand on-site observation. Many high-frequency groundwater-quality monitoring stations have transmitters that enable the logged data to be downloaded remotely from the field; other stations have electronic data loggers (EDLs) that record sonde data for retrieval only during site visits; and still other stations have only internal logging enabled on the sonde for data retrieval during site visits or as a data back-up. Whichever is the case, convert raw data into a standard format for NWIS-TS database storage by using the Device Conversion and Delivery System (DECODES; for real-time high-frequency data; Wagner and others, 2006), or by using the "Append Logger" within the NWIS-TS database (for non-real-time high-frequency data and back-up data appending). Field and office personnel will coordinate with their LDMs to properly configure DECODES, Append Logger, and EDL files or backup sonde files for loading into the NWIS-TS database.

Missing or erroneous data (for example, because of programming issues or instrument and transmission problems) should be documented and excluded from the period of record. Similarly, when secondary logger data are used as sources of backup data, documentation will be created where the secondary logger data are appended to the record. Situations such as these (and many others) should be documented in the NWIS-TS database using appropriate qualifiers. Qualifiers are assigned to specific periods of the time-series data record and are used to mark data according to a structured set of situations. There are two levels of qualifiers available for use in the NWIS-TS database (1) permanent qualifiers (applied to both provisional and approved data) and (2) temporary qualifiers (applied to provisional data only).

Permanent qualifiers are retained in the approved record and can be applied to the one period of record or overlapping periods of record. The three permanent qualifiers appropriate for a groundwater setting are (1) GREATERTHAN (actual value known to be greater than reported value), (2) LESSTHAN (actual value known to be less than reported value), and (3) REVISED (approved data value revised after initial publication). Note that the estimation qualifier (ESTIMATED) should not be used for the time-series data record in a groundwater setting.

Temporary qualifiers are most often used to suppress erroneous data from public view until a site visit to correct the problem(s) is made. The seven temporary qualifiers that are appropriate for a groundwater setting are (1) EQUIP (equipment malfunction), (2) MAINT (maintenance in progress), (3) DISCONTINUED (discontinued station), (4) UNAVAIL (data temporarily unavailable), (5) PARTIAL RECORD (partial station record), (6) TEST (data that are collected specifically for or during intentionally conducted tests), and (7) PUMP (data that are collected during well purging). Once the period of record is approved, many of these qualifiers automatically disappear, and those that do not should be removed manually. 


\section{Pre-Processing Corrections}

The removal of data logged during non-pumping and non-operational periods and the de-spiking of the data series are considered "Pre-Processing" corrections to the record. Communication with well owners, flow indicator or pump activity (deflectometer) data, and a documentation of specific station operations is critical to identify and remove erroneous data generated during non-pumping and non-operational periods. For high-capacity supply wells, it is important to obtain a copy of the groundwater pumping records from the operator as the first step to identifying non-operational periods. For domestic supply wells, communication with the well owner is critical for identifying possible non-pumping and non-operational periods. For all well classifications, if there are existing non-target wells collecting continuous water level time-series data that also have hydraulic connectivity with the target well, then the water level time-series data record from the non-target well can often be used to determine when pumping periods have or have not occurred at the target well.

Despite the inclusion of flow switches which activate sensor measurements when groundwater pumps are active and water flow is greater than a set rate, unrepresentative water may still be monitored by the water-quality instrumentation during non-operational periods and transmitted to the NWIS-TS database. This results in the sonde monitoring the stagnant water in the flow cell (or canister for optical nitrate sensors) and transmitting this erroneous data. Other non-operational situations include monitoring stagnant water during well maintenance, monitoring back-pressure water from water systems or storage tanks, or monitoring stagnant water when the well owners or operators inadvertently turned off the water flow at the hose-bib fitting. Note that a processor could be set up in the NWIS-TS database to automatically suppress data when the well is not pumping per flow switches or some similar kind of flow indicator. Detailed discussions and descriptions of this process are outside the scope of this report and field or office personnel are encouraged to work with their LDM on this or any kind of auto-suppression regimes in the NWIS-TS database.

Despite the efforts taken to prevent the collection of data unrepresentative of aquifer conditions during non-operational periods, water-quality data are inevitably collected when pumps are off, undergoing maintenance, or during site visits. Short periods of unrepresentative data are known as erroneous data spikes or erroneous periods. Data spikes most commonly result from regularly scheduled data transmissions during site visits, slow sensor stabilization after site visits, short-term power outage or electrical surge events, or other stationspecific causes of data transmission instability. Eliminate all data spikes (de-spike) from the NWIS-TS period of record by using the "Outlier Trim Correction" in the Data Correction Toolbox. The outlier trim correction can remove erroneous data spikes that are within the upper and lower time-series thresholds. Field or office personnel should set the outlier trim deviation value (from average, maximum, or minimum) high or low enough to remove the erroneous data but leave the valid data alone. Only use the outlier trim correction to remove large data spikes, and regularly review open-ended outlier trim corrections to ensure they are not deleting valid data. Small data spikes will need to be removed manually from the NWIS-TS database by using the "Delete Region Correction" or "Adjustable Trim Correction" in the Data Correction Toolbox.

\section{Applying Data Corrections}

The application of data corrections for sensor fouling and calibration drift error are considered "Pre-Processing", and "Normal-Processing" corrections to high-frequency data, respectively. However, they are applied using the USGS Multi-Point Correction tool with the automatically suggested correction algorithm in the NWIS-TS "Field Data Editor" module and applied as "set 1" for a fouling correction (identical in processing priority to "Pre-Processing") and "set 2" for a calibration drift correction (identical in processing priority to "Normal-Processing").

Wagner and others (2006) established Data Correction Criteria to identify when it is necessary to apply corrections to the high-frequency water-quality data; if the sum of the absolute values of the sensor fouling and calibration drift errors is greater than or less than the ranges presented for each field parameter (table 8), then corrections for sensor fouling and calibration drift are required. This report recommends that high-frequency groundwater-quality data will always be corrected for detectable sensor fouling and presents new Sensor Recalibration Thresholds that, when exceeded require data corrections for calibration drift error (table 8). The equations for calculating sensor fouling and calibration drift error used in this report are the same as presented in Wagner and others (2006).

\section{Corrections for Sensor Fouling}

Sensor fouling is a "set 1" data correction in the NWIS-TS database and is applied to a time-series data record before it is corrected for calibration drift error. Sensor fouling in a groundwater environment is typically less significant than in a surface water environment, and changes in groundwater chemistry tend to be slower and lower in magnitude. Detectability of slow and subtle changes in the groundwaterquality data is more sensitive to sensor fouling, hence, this report recommends always applying the sensor fouling (set 1 ) correction to high-frequency groundwater-quality data. The effects of sensor fouling are documented during groundwater site visits using the "steady-state conditions" sensor fouling equation in Wagner and others (2006). 
Table 8. Sensor recalibration and data-correction thresholds for high-frequency water-quality monitoring sensors deployed at groundwater- and surface-water quality stations.

[CT, calibration threshold; EV, expected temperature-compensated standard (or buffer) value; mg/L, milligrams per liter; na, not available; P, manufacturer's stated sensor precision (in units); \%, percent; \pm , plus or minus; $\mu \mathrm{S} / \mathrm{cm}$, microsiemens per centimeter at 25 degrees Celcius $\left({ }^{\circ} \mathrm{C}\right.$ )]

\begin{tabular}{|c|c|c|c|}
\hline $\begin{array}{c}\text { Field } \\
\text { parameter }\end{array}$ & $\begin{array}{l}\text { Groundwater-quality stations } \\
\text { monitoring low-velocity conditions }\end{array}$ & $\begin{array}{l}\text { Groundwater-quality stations } \\
\text { monitoring rapidly changing conditions }\end{array}$ & Surface-water quality stations ${ }^{1}$ \\
\hline \multicolumn{4}{|c|}{ Sensor recalibration threshold } \\
\hline $\begin{array}{l}\text { Specific conductance } \\
\text { Dissolved oxygen } \\
\mathrm{pH}\end{array}$ & $\begin{array}{l}\text { - Recalibrate sensor when values } \\
\text { are outside the range established by } \\
C T=(E V) \pm(P) \text {. }\end{array}$ & $\begin{array}{l} \pm 2 \mu \mathrm{S} / \mathrm{cm} \text { or } 1 \% \text { of the measured } \\
\quad \text { value, whichever is greater }{ }^{2} . \\
\pm 0.1 \mathrm{mg} / \mathrm{L}^{2} \\
\pm 0.1 \mathrm{pH} \text { units }^{2}\end{array}$ & $\begin{array}{l} \pm 5 \mu \mathrm{S} / \mathrm{cm} \text { or } 3 \% \text { of the measured } \\
\quad \text { value, whichever is greater. } \\
\pm 0.3 \mathrm{mg} / \mathrm{L} \\
\pm 0.2 \mathrm{pH} \text { units }\end{array}$ \\
\hline Nitrate & $\begin{array}{l} \pm 2 \text { through } 10 \% \text { depending on sensor } \\
\text { model }^{3} \text {. }\end{array}$ & $\begin{array}{l} \pm 2 \text { through } 10 \% \text { depending on sensor } \\
\text { model }^{3} \text {. }\end{array}$ & na \\
\hline \multicolumn{4}{|c|}{ Data-correction threshold } \\
\hline Temperature & $\pm 0.2{ }^{\circ} \mathrm{C}^{1}$ & $\pm 0.2{ }^{\circ} \mathrm{C}^{1}$ & $\pm 0.2^{\circ} \mathrm{C}$ \\
\hline Specific conductance & $\begin{array}{l}\text { - Always apply the sensor fouling } \\
\text { (set 1) correction to the data record. }\end{array}$ & $\begin{array}{l} \pm 2 \mu \mathrm{S} / \mathrm{cm} \text { or } 1 \% \text { of the measured } \\
\text { value, whichever is greater }{ }^{2} .\end{array}$ & $\begin{array}{l} \pm 5 \mu \mathrm{S} / \mathrm{cm} \text { or } 3 \% \text { of the measured } \\
\text { value, whichever is greater. }\end{array}$ \\
\hline Nitrate & $\begin{array}{l} \pm 2 \text { through } 10 \% \text { depending on sensor } \\
\text { model }^{3} \text {. }\end{array}$ & $\begin{array}{l} \pm 2 \text { through } 10 \% \text { depending on sensor } \\
\text { model }^{3} \text {. }\end{array}$ & na \\
\hline
\end{tabular}

\section{Corrections for Calibration Drift Error}

Calibration drift error is the primary factor affecting the accuracy of high-frequency groundwater-quality measurements. Calibration drift error has been described as the electrical drift in a sensor reading since the last time the sensor was calibrated (Wagner and others, 2006). The "slowly changing conditions" equation presented in Wagner and others (2006) should be used to document calibration drift error, which is a "set 2" correction in the NWIS-TS database.

\section{Sensor Recalibration and Data-Correction Thresholds}

The updated sensor recalibration and data-correction thresholds for groundwater-quality data established in this report define guidelines for the recalibration of groundwaterquality sensors and the correction of high-frequency groundwater-quality data at (1) groundwater wells with low groundwater velocity and (2) groundwater wells with rapidly changing conditions (table 8). These recalibration and datacorrection thresholds are based on testing and confirmation of the manufacturer stated sensor precision (through laboratory experiments using three available state-of-the-art water-quality sensors; appendix 1; Mathany and Saraceno, 2019), recent accuracy tests by the USGS (Snazelle, 2015), and NAWQA ETN Project site-visit measurements and time-series waterquality data (appendix 1).

At groundwater-quality stations monitoring low-velocity conditions, the set 1 (sensor fouling) correction should always be applied and the set 2 (calibration drift error) data correction should also be applied to the time-series data record if a recalibration was prescribed based on the calibration threshold, calculated by using equation 4 . These actions will proactively prevent sensor fouling and calibration drift errors (known bias) from altering the final time series, increasing data noise, and potentially misinforming the user. For example, if this erroneous data is left uncorrected, it can frequently lead to the misinterpretation of groundwaterquality "trends" in the final time series at groundwater stations monitoring low-velocity conditions. 
High-frequency groundwater-quality data collected over several years, from many types of wells in different aquifer systems for the NAWQA ETN Project indicate that more stringent sensor recalibration and data-correction threshold guidance are needed to accurately correct groundwaterquality time-series data recorded at stations monitoring low-velocity conditions. For example, the existing SC recalibration guidance states that for check measurements using a conductance standard of $1,000 \mu \mathrm{S} / \mathrm{cm}$ at $25^{\circ} \mathrm{C}$, the recalibration threshold is 3 percent of the measured standard $\left(30 \mu \mathrm{S} / \mathrm{cm}\right.$ at $\left.25^{\circ} \mathrm{C}\right)$. This threshold, $\pm 30 \mu \mathrm{S} / \mathrm{cm}$ at $25^{\circ} \mathrm{C}$, in a groundwater-quality record is larger than many observed changes in groundwater chemistry over long periods of time, and as such, allows too much sensor fouling or uncorrected calibration drift error to discern real water-quality changes in most groundwater systems. At stations monitoring lowvelocity groundwater conditions, more stringent thresholds are required, and smaller tolerances are defensible.

The following two examples demonstrate how sensitive a groundwater-quality time-series data record can be to improperly accounting for calibration drift error and applying corrections based on current data-correction criteria. Figure 12 shows the raw and corrected $\mathrm{pH}$ measurements at USGS station 364200119420001 in August and September 2017 and from the associated site visit at the end of the displayed period. During this site visit, the total observed calibration drift error was $0.15 \mathrm{pH}$ units.

Figure 14 shows the raw and corrected SC measurements at the 234-foot (ft) deep well (USGS station 364200119420003, table 2) in February and March 2018 and from the associated site visit at the end of the displayed period. During this site visit an approximately $6 \mu \mathrm{S} / \mathrm{cm}$ at $25^{\circ} \mathrm{C}$ calibration drift error in check measurements using a $1,000 \mu \mathrm{S} / \mathrm{cm}$ at $25^{\circ} \mathrm{C}$ standard was observed.

When current recalibration and data-correction thresholds are applied, the $\mathrm{pH}$ and the $\mathrm{SC}$ sensors are considered to be functioning accurately, and sensor recalibrations are not recommended. As a result, calibration drift error corrections would not be applied for the periods of record (shown as raw $[\mathrm{pH}]$ lines and dots in fig. 12; and raw [SC] in fig. 14). This would result in the data indicating a groundwaterquality "trend" in the data over the period of record at USGS well 364200119420001 (pH increasing) and USGS well 364200119420003 (SC decreasing). These errors in the groundwater-quality time-series data could be repeated in subsequent periods of record, and potentially be compounded by further inaction during subsequent site visits.

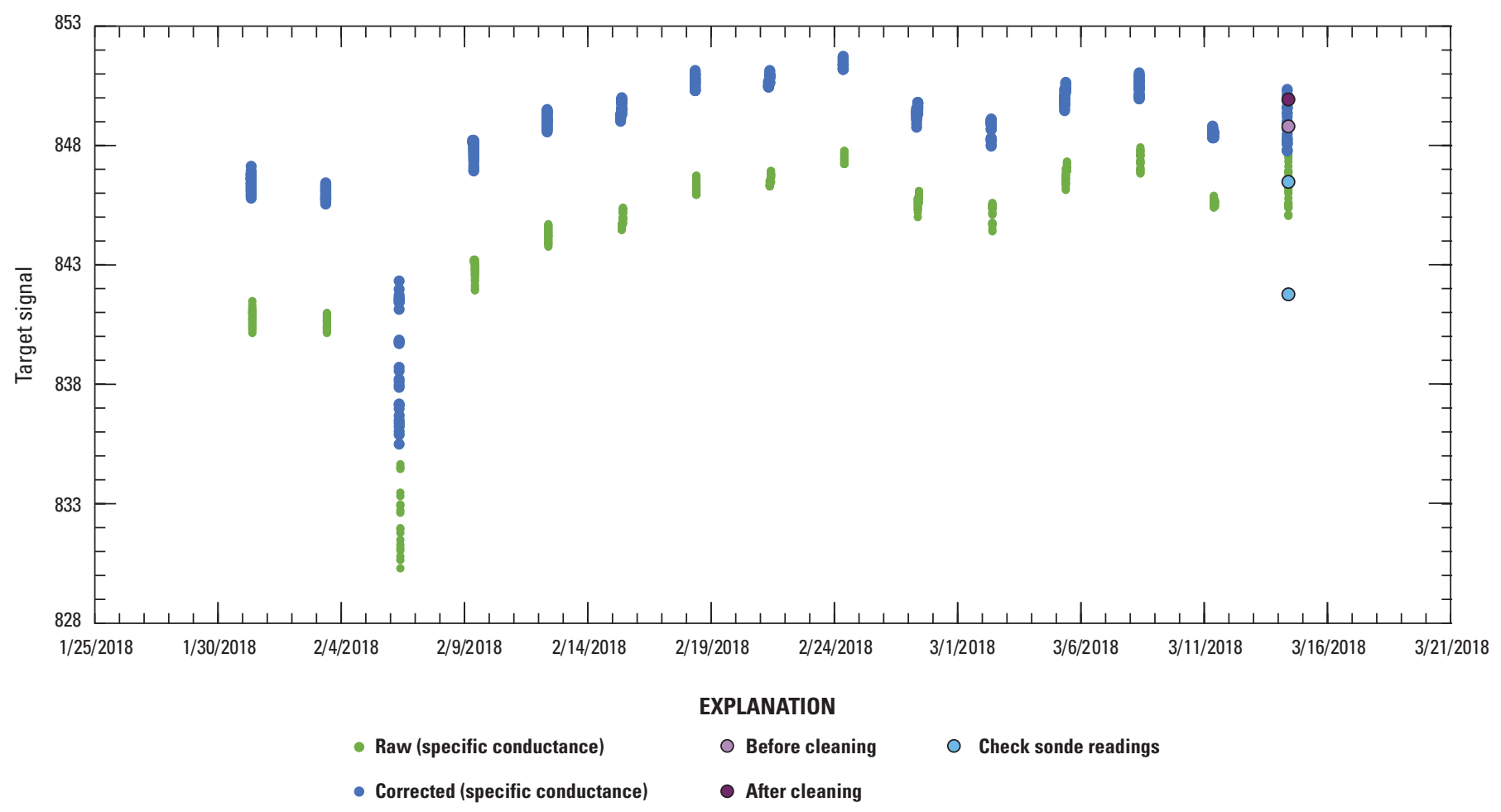

Figure 14. Raw and corrected specific conductivity time-series data and data from end of period site visit at USGS station 364200119420003, February and March 2018. 
At groundwater-quality stations monitoring rapidly changing conditions (such as wells located in shallow, karst, or rapidly recharging aquifer systems), groundwater chemistry changes are larger in magnitude and more rapid than groundwater stations monitoring low-velocity conditions. At these stations, groundwater conditions are much more like a surface water environment; therefore, a refining of the existing recalibration and data-correction thresholds presented in Wagner and others (2006) based on the results of recent sensor accuracy tests from Snazelle (2015) was deemed appropriate to correct these groundwater-quality time-series data records and begin assessing water-quality trends at groundwaterquality stations monitoring rapidly changing conditions.

\section{Data Corrections}

Professional judgement should be used to make datadriven decisions when determining whether to apply data corrections in NWIS-TS. To begin the process of applying data corrections, the sensor fouling checks and calibrations QC data (deployed sonde and check sonde), and site-visit information generated using the standard maintenance procedure (table 3 ) are converted into digital form (.xml file in the NWIS-TS database format) using the USGS SVMobileAQ program. The USGS SVMobileAQ program can be used exclusively or field personnel can use it in conjunction with the USGS High-Frequency Groundwater-Quality Field Form. The converted .xml file is then uploaded directly into the NWIS-TS database, where these data assist field and office personnel in correcting the period of record and to determine the error caused by sensor fouling and calibration drift.

Within the NWIS-TS database, the set 1 (sensor fouling) and set 2 (calibration drift error) data corrections are applied to the period of record "automatically" or "manually." Personnel can apply data corrections for all field parameters automatically by using the automatically suggested corrections tool in the "Visits" menu tab of the USGS NWIS database, also known as the "Field Data Editor". To process corrections using the files created in the USGS SVMobileAQ program, either (1) "drag and drop" the .xml files directly into the "import data box" or (2) select the .xml files from a specific location on the computer by using the "select files button" to open a file browser.

Data corrections can also be applied manually for each field parameter in the NWIS-TS database by using the USGS High-Frequency Groundwater-Quality Field Form and the "USGS Multi-Point Correction" in the Data Correction Toolbox. To apply a manual correction of the time series for each field parameter, (1) highlight the period of record to be corrected, (2) manually enter the sensor fouling and calibration drift correction values into the USGS Multi-Point Correction tool, and then (3) apply the corrections.

\section{Finalizing Data Evaluation}

All high-frequency groundwater-quality time-series data records will be analyzed, approved, and audited by procedures and guidelines set forth by the U.S. Geological Survey (2017a). All data used in producing the final high-frequency groundwater-quality record will be checked thoroughly for completeness and accuracy before the final data evaluation. The field and office personnel who are responsible for computing the high-frequency groundwater-quality record will evaluate the unapproved period of record for each field parameter and prepare the review package in a timely manner according to USGS Continuous Records Processing (CRP) policy using the USGS RMS, an internal tool used to track records processing progress of USGS Water Science Centers nationally. All field data will be verified for accuracy to assure that the correct values were used for the data corrections and all period of record dates and times should be checked for accuracy. USGS RMS contains embedded templates that can be modified for use at high-frequency groundwater-quality stations to ensure a consistent process in analyzing, approving, and auditing time-series water-quality data records.

\section{Maximum Allowable Limits for Reporting High-Frequency Groundwater-Quality Data}

Maximum allowable limits (MALs) refer to the concept that when the corrected values differ from the raw values by more than the MALs, the corrected data are not reported or stored in the NWIS-TS database. This report uses the same MAL methods (6-10 times the calibration criteria) as used in Wagner and others (2006) but updates the MAL values for each high-frequency groundwater-quality parameter (table 9). In this report the MAL values are established at 6-10 times the "groundwater stations monitoring rapidly changing conditions" data-correction threshold values (table 8).

\section{Finalizing the Data in the NWIS-TS Database}

To complete the final data evaluation process, field or office personnel will "age" the data in the NWIS-TS database. Reclassifying the data from "Working" to "Analyzed" signals that the high-frequency groundwater-quality data for the period of record is ready to move forward in the review process. This action also "locks" the groundwater-quality data in the NWIS-TS database, assuring there is no accidental data loss or modification of data while the data review is being prepared. The following steps are given for record analysis and approval workflow in the NWIS-TS database:

1. Log in to the NWIS-TS database.

2. Find the groundwater-quality station and select the field parameter to be aged (analyzed or approved). 
Table 9. Maximum allowable limits guidance for correction of raw field-measured values of field parameters and nitrate for groundwater-quality monitoring stations and surface-water quality monitoring stations from Wagner and others (2006).

[mg/L, milligrams per liter; na, not available; \%, percent; \pm , plus or minus; ${ }^{\circ} \mathrm{C}$, degrees Celsius]

\begin{tabular}{lll}
\hline \multicolumn{1}{c}{ Field parameter } & \multicolumn{1}{c}{$\begin{array}{c}\text { Maximum allowable limit for } \\
\text { groundwater-quality sensor values }\end{array}$} & \multicolumn{1}{c}{$\begin{array}{c}\text { Maximum allowable limits for } \\
\text { surface water-quality sensor values }\end{array}$} \\
\hline Temperature & $\pm 2.0{ }^{\circ} \mathrm{C}$ & $\pm 2.0^{\circ} \mathrm{C}$ \\
Specific conductance & \pm 6 to $10 \%$ & $\pm 30 \%$ \\
Dissolved oxygen & \pm 0.6 to $1.0 \mathrm{mg} / \mathrm{L}$ & $\pm 2.0 \mathrm{mg} / \mathrm{L}$ or $20 \%$, whichever is greater \\
$\mathrm{pH}$ & \pm 0.6 to $1.0 \mathrm{pH}$ units & $\pm 2 \mathrm{pH}$ units \\
Nitrate & $\pm 30 \%$, depending on sensor ${ }^{1}$ & na \\
\hline
\end{tabular}

${ }^{1}$ Guidance from Pellerin and others, 2013.

3. Click the "Approval" button (check mark) at the top of the webpage.

4. Select the dates for the period of record to be aged, typically between site visits or quarterly, by clicking a "Working" period or specify by using the "Choose Date" slider.

5. Change the status of the period of record by selecting "Analyzed" from the pull-down box; then click "Save."

Once the field or office personnel have set the status code for all data for each field parameter to "Analyzed" in the NWIS-TS database, the final data evaluation is finished and the groundwater-quality data for the period of record are ready for record-finalization and the records review processes.

\section{Finalizing Record and Documentation}

The record-finalization process starts with the creation and completion of the "Station Analysis" for each field parameter in USGS RMS (typically produced by the same individual who services the groundwater-quality monitoring station). Once the station analysis is complete, the CRP section of USGS RMS can be updated, set to analyzed, and the records review can commence. After the records review is complete, the NWIS-TS period of record can be (1) approved and audited (when applicable) by an experienced, qualified "analyst," "approver," and "auditor" (U.S. Geological Survey, 2017a) and (2) approved in USGS RMS. The "Documentation" section highlights various USGS memoranda that should be followed by field and office personnel to publish the high-frequency water-quality data generated during each period of record in a timely and accurate manner.

\section{Components of the Final Records Review}

At a minimum for a complete records review, each of the "components" and the NWIS-TS database will be officially and independently examined for completeness and accuracy at least once by an experienced, qualified analyst before the final records approval by a qualified approver. A complete final records review for high-frequency groundwater-quality records will include a thorough examination of the following figures, forms, and reports for each measured field parameter (examples are included as appendixes for reference):

- Station Description (can be included as an online link on station analysis; appendix 3).

- Station Analysis (appendix 4).

- Standard Maintenance Procedure results.

- Plots of the raw and corrected instantaneous values (for example, figs. 12, 14).

- USGS NWIS-Time Series Data Report.

The final records review should be a thorough examination of the groundwater-quality time-series data records by the analyst and approver for the period of record. To aid in this effort, two checklists were created as a guide to each reviewer in the suggested steps required to accurately and expeditiously complete a final records review. The use of these checklists is not mandatory, but both are included as appendixes in this report for reference.

- High-Frequency Groundwater-Quality Record Analyst Checklist (appendix 5).

- High-Frequency Groundwater-Quality Record Approver Checklist (appendix 6).

\section{Station Description}

Detailed information about each high-frequency groundwater-quality station is required to be documented in the online station description in USGS RMS (appendix 3). The online link for the USGS SIMS station description will be included in the "Water-Quality Measurements" section of the station analysis. 


\section{Station Analysis}

Every field-measured parameter at the groundwaterquality monitoring station will have a separate station analysis for each period of record. The station analysis includes all the contents required for the finalization of the groundwaterquality records for the period of record. The station analysis will be analyzed and approved following the peer review process described in USGS RMS (appendix 4). The station analysis will include a link to the USGS NWIS-Time Series Data Report for each period of record.

\section{Standard Maintenance Procedure Results}

The final records review includes a thorough evaluation of the site visit and monitoring data generated during the Standard Maintenance Procedure. This involves a complete examination of the USGS SVMobileAQ program file or the electronic USGS High-Frequency Groundwater-Quality Field Form (appendix 2) from each site visit during the period of record.

\section{Plots of the Raw and Corrected Instantaneous Values}

The final records review includes an examination of the RIVs and CIVs plots for each water-quality parameter during the period of record (for example, figs. 12 and 14). The RIVs and CIVs plots should be those generated with the NWIS-TS data using the Data Correction Toolbox. The plots can be saved in NWIS-TS by using the Data Correction Toolbox's "Save View" function to document comparison or "surrogate" time series used during the records review.

The RIVs plot includes all the raw instantaneous values, including data that was excluded because of time-series threshold suppression, open-ended outlier trim correction, pump-off events, power outages, data gaps, data spikes, and other erroneous data; and includes the QC values observed during site visits. The CIVs plot contains the corrected instantaneous values after set 1 and set 2 data corrections, time-series thresholds, open-ended outlier trim corrections, and excluding pump-off events, power outages, data spikes, and any other erroneous data during the period of record. The CIVs plot is considered a "clean" plot of the high-frequency groundwater-quality time-series data record that will be released to the public after final USGS approval.

\section{USGS NWIS Time-Series Data Report}

The final records review includes an examination of the USGS NWIS-Time Series Data Report generated for each groundwater-quality parameter during the period of record (https://reporting.nwis.usgs.gov/timeseries/index.jsp) and should be included as a link in the station analysis. The report summarizes the time-series data record attributes; gaps in the time-series data record; type, timing, and extent of any data corrections (pre-processing, normal, and post-processing); time-series thresholds, open-ended outlier trim corrections, and metadata for each groundwater-quality parameter over the period of record.

\section{Approving of Groundwater-Quality Records}

The final records approval is done by a designated qualified approver, who validates the "components of a records review" signifying that the time-series data for the period of record can then be changed from "analyzed" to "approved" in the NWIS-TS database. The approved period of record can now be finalized in the CRP section of USGS RMS.

In USGS RMS, for each period of record, if elements of interpretation were involved (for example, when to start or terminate a data correction) the correction decisions will be documented within the station analysis. If the CRP approval template (in USGS RMS) for the period of record shows that the analyst did not complete a thorough records-review analysis, the record can be pushed back in USGS RMS by the approver for re-analysis.

\section{Auditing of Groundwater-Quality Records}

The purpose of auditing groundwater-quality records is to ensure proper methods are applied throughout the process of obtaining groundwater-quality data and computing records. Routine audits are completed independently of the CRP process and are meant to include at least a year or more of time-series data records to look for more general quality issues or patterns that could impact data quality. Groundwaterquality time-series data records should be audited at intervals of about 1 year and no less than every 15 months, by qualified personnel, per USGS standard procedures and requirements (U.S. Geological Survey, 2017a). In addition, at least one CRP period within the audited period should be audited with the same level of detail as the approval level. If errors are found and revisions recommended due to an audit, the data are to be amended if they meet existing revision criteria (U.S. Geological Survey, 2017b).

\section{Documentation}

All high-frequency groundwater-quality monitoring timeseries data records are documented, characterized, processed, and published based on the guidance provided in USGS policy and technical memoranda (U.S. Geological Survey, 2010, 2017a, 2017c). If applicable, procedures for identifying and documenting data revisions to approved USGS high-frequency groundwater-quality time-series data records are available in U.S. Geological Survey (2017b).

\section{Archiving the Records}

All original groundwater-quality time-series data is archived using the procedures set forth by the USGS Guidelines for the Preservation of Digital Scientific Data (U.S. Geological Survey, 2014). The records archives should be maintained until the records reach the disposition timelines set out by the USGS Scientific Records Disposition Schedule (U.S. Geological Survey, 2006). 


\section{Summary}

High-frequency groundwater-quality monitoring stations provide high-resolution data to improve understanding of the timing of water-quality changes in the subsurface, especially for aquifer systems with short groundwater-residence times. High-frequency time-series data are used to monitor surfacewater to groundwater interaction, quantify contaminant transport rates, and study water-quality variability in relation to variability of precipitation and groundwater pumping rates. Common instrumentation for high-frequency groundwaterquality data collection is a multi-parameter sonde with sensors that record water temperature, specific conductance, $\mathrm{pH}$, and dissolved oxygen. Other parameters such as nitrate, fluorescent dissolved organic matter, and turbidity can also be monitored at high frequency. Following water-quality sonde operational procedures and a standard record-computation process are part of the required quality assurance for producing and documenting complete and accurate highfrequency groundwater-quality monitoring records.

The goal of this report is to provide specific guidelines for the monitoring station set-up for various well types, the use of water-quality sensors for high-frequency groundwater-quality monitoring, to refine guidance for data corrections, and make appropriate updates to the records computation procedures. This report supplements previous continuous surface-waterquality monitoring guidance documents for water temperature, specific conductance, $\mathrm{pH}$, dissolved oxygen, and nitrate. The specific groundwater-quality monitoring guidelines presented in this report cover station selection, design, installation, and operations; sensor inspections, cleaning and calibration methods; troubleshooting procedures; data evaluations; data corrections; record-computation; and record review, approval, and auditing procedures for the groundwater environment.

To ensure collection of representative high-frequency groundwater-quality time-series data, stations are selected based upon aquifer conditions (for example, conductivity and porosity), well construction information, and location providing access to the well site. Stations are designed, installed, and operated to monitor groundwater quality, and to record and transmit data. Accurate information is collected when the updated standard maintenance procedures are followed for the application of corrections to the groundwaterquality time-series data record, the inspection, troubleshooting, cleaning, and recalibrating of sondes and sensors. The data-evaluation, data-correction, and record-computation guidance presented in this report is specifically intended for the groundwater environment, where temporal changes in water quality in many aquifers are slow compared with those in surface water, and the magnitude of the changes in water quality also are smaller. Collecting and evaluating highfrequency groundwater-quality time-series data according to these new procedures, results in lower uncertainties and stricter tolerances than when using previous water-quality monitoring guidelines. The high-frequency groundwaterquality record-computation procedures in this report follow current guidance but are updated (where required) to reflect application to a groundwater environment.

\section{References Cited}

Arnold, T.L., DeSimone, L.A., Bexfield, L.M., Lindsey, B.D., Barlow, J.R., Kulongoski, J.T., Musgrove, M., Kingsbury, J.A., and Belitz, Kenneth, 2016, Groundwater quality data from the National Water-Quality Assessment Project, May 2012 through December 2013 (ver. 1.1, November 2016): U.S. Geological Survey Data Series 997, 56 p., https://doi.org/10.3133/ds997.

Arnold, T.L., Bexfield, L.M., Musgrove, M., Lindsey, B.D., Stackelberg, P.E., Barlow, J.R., DeSimone, L.A., Kulongoski, J.T., Kingsbury, J.A., Ayotte, J.D., Fleming, B.J., and Belitz, Kenneth, 2017, Groundwaterquality data from the National Water-Quality Assessment Project, January through December 2014 and select qualitycontrol data from May 2012 through December 2014: U.S. Geological Survey Data Series 1063, 83 p., https://doi.org/10.3133/ds1063.

Benson, B.B., and Krause, D., Jr, 1980, The concentration and isotopic fractionation of gases dissolved in freshwater in equilibrium with the atmosphere. 1. Oxygen: Limnology and Oceanography, v. 25, no. 4, p. 662-671, http://www.jstor.org/stable/pdfplus/2835754.pdf.

Benson, B.B., and Krause, D. Jr, 1984, The concentration and isotopic fractionation of oxygen dissolved in freshwater and seawater in equilibrium with the atmosphere: Limnology and Oceanography, v. 29, no. 3, p. 620-632, https://aslopubs.onlinelibrary.wiley.com/doi/epdf/10.4319/ lo.1984.29.3.0620.

Campbell Scientific Incorporated, 2018, CR1000 Datalogger Operator's Manual—Revision 2/18, 630 p., accessed September 4, 2018, at https://s.campbellsci.com/documents/ us/manuals/cr1000.pdf.

Cunningham, W.L., and Schalk, C.W., comps., 2011, Groundwater technical procedures of the U.S. Geological Survey: U.S. Geological Survey Techniques and Methods 1-A1, 151 p., https://pubs.usgs.gov/tm/1a1/pdf/tm1-a1.pdf.

Design Analyses Associates Incorporated, 2014, Model H-223 GOES Satellite Antenna (401.7 to $402.85 \mathrm{MHz}$ ) Owner's Manual: Version 1.1, 9 p., accessed September 4, 2018, at http://www.manualsdir.com/manuals/310791/xylem-h-223. html? original $=1$. 
Etheridge, J.R., Birgand, F., Burchell, M.R., II, and Smith, B.T., 2013, Addressing the fouling of in situ ultraviolet-visual spectrometers used to continuously monitor water quality in brackish tidal marsh waters: Journal Environmental Quality, v. 42, no. 6, p. 1896-1901, accessed December 18, 2017, at https://doi.org/10.2134/jeq2013.02.0049.

Eureka Environmental Engineering, 2016, Manta 2 Water Quality Multiprobe Manual: 51 p., accessed October 19, 2017, at http://www.rshydro.co.uk/PDFs/ Eureka/Manta2-manual.pdf.

Ficken, J.H., and Scott, C.T., 1989, Operating manual for the U.S. Geological Survey minimonitor-Analogvoltage model: U.S. Geological Survey Open-File Report 89-403, 55 p., accessed October 20, 2017, at http://pubs.er.usgs.gov/pubs/ ofr/ofr89403.

Freeman, L.A., Carpenter, M.C., Rosenberry, D.O., Rousseau, J.P., Unger, R., and McLean, J.S., 2004, Use of submersible pressure transducers in waterresources investigations: U.S. Geological Survey Techniques of Water Resources Investigations, book 8, chap. A3, 50 p., accessed June 28, 2018, at https://pubs.usgs.gov/twri/twri8a3/pdf/twri8-a3.pdf.

Garinger, L.P., King, A.S., and Ziegler, A.C., 2011, Effects of experimental passive artificial recharge of treated surface water on water quality in the Equus Beds Aquifer, 20092010: U.S. Geological Survey Scientific Investigations Report 2011-5070, 106 p., accessed April 24, 2018, at https://pubs.usgs.gov/sir/2011/5070/pdf/sir2011_5070.pdf.

Geotech Environmental Equipment Incorporated, 2019, Geotech Colloidal Borescope installation and operations manual, 42 p., accessed April 5, 2019, at http://www.geotechenv.com/Manuals/Geotech_Colloidal_ Borescope.pdf.

Gibs, J., Wilde, F.D., and Heckathorn, H.A., 2007, Use of multiparameter instruments for routine field measurements (ver. 1.0): U.S. Geological Survey Techniques of WaterResources Investigations, book 9, chap. A6, section 6.8, accessed August 15, 2017, at http://water.usgs.gov/owq/ FieldManual/Chapter6/6.8_contents.html.

Hach Company, 2014, pH electrode cleaning \& maintenance guide, 4 p., accessed June 16, 2018, at https://www.hach.com/asset-get.download. jsa?id=11147536803.

Hach Company, 2016, Model 3422-series Compression fitting style contacting conductivity/resistivity sensors: Operating Instruction Manual, 21 p., accessed July 2, 2018, at https://www.hach.com/asset-get.download. jsa?id=7639983080.
Hanna Instruments Incorporated, 2014, Reliable and waterproof multi-range conductivity meters: HI 8633 HI 8733 - HI 8734 Instruction Manual, 20 p., accessed July 2, 2018, at https://hannainst.com/downloads/dl/file/ id/1147/man8734y_14_07_10.pdf.

Hanna Instruments Incorporated, 2017, pH Electrode Maintenance Guide, 2 p., accessed June 16, 2018, at https://hannainst.com/resources/ph/guides/ph-electrodemaintenance-guide--hanna-instruments.pdf.

Huebsch, M., Grimmeisen, F., Zemann, M., Fenton, O., Richards, K.G., Jordan, P., Sawarieh, A., Blum, P., and Goldscheider, N., 2015, Technical noteField experiences using UV/VIS sensors for highresolution monitoring of nitrate in groundwater: Hydrology and Earth System Sciences, v. 19, no. 4, p. 1589-1598, accessed December 18, 2017, at https://www.hydrol-earth-syst-sci.net/19/1589/2015/hess19-1589-2015.pdf.

Huffman, R.L., 2014, Groundwater geochemical and selected volatile organic compound data, Operable Unit 1, Naval Undersea Warfare Center, Division Keyport, Washington, July 2013: U.S. Geological Survey Data Series 871, 46 p., accessed June 28, 2018, at https://doi.org/10.3133/ds871.

Huffman, R.L., 2015, Groundwater geochemical and selected volatile organic compound data, Operable Unit 1, Naval Undersea Warfare Center, Division Keyport, Washington, June and September 2014: U.S. Geological Survey Data Series 920, 50 p., accessed June 28, 2018, at https://doi.org/10.3133/ds920.

Insite Instrumentation Group Incorporated, 2017, Single channel analyzer user manual, 49 p., accessed June 18, 2018, at https://www.insiteig.com/pdfs/SCAManual-CE-12-Jan-17.pdf.

Lapham, W.W., Hamilton, P.A., and Myers, D.N., 2005, National Water-Quality Assessment ProgramCycle II-Regional assessments of aquifers: U.S. Geological Survey Fact Sheet 2005-3013, 4 p., https://pubs.usgs.gov/fs/2005/3013/pdf/PASforWeb.pdf.

MacDonald, G., Levison, J., and Parker, B., 2017, On methods for in-well nitrate monitoring using optical sensors: Groundwater Monitoring and Remediation, v. 37, no. 4, p. 60-70, accessed July 10, 2018, at https://doi.org/10.1111/gwmr.12248.

Mathany, T.M., and Saraceno, J.F., 2019, Electrical conductivity, $\mathrm{pH}$, and dissolved oxygen time-series data generated from the short-term precision experiment and the long-term field precision analysis to characterize waterquality sondes for the Guidelines and Standard Procedures for High-Frequency Groundwater-Quality Monitoring Station Techniques and Methods Report: U.S. Geological Survey data release, https://doi.org/10.5066/P9QLWSBS. 
Oelsner, G.P., Sprague, L.A., Murphy, J.C., Zuellig, R.E., Johnson, H.M., Ryberg, K.R., Falcone, J.A., Stets, E.G., Vecchia, A.V., Riskin, M.L., De Cicco, L.A., Mills, T.J., and Farmer, W.H., 2017, Water-quality trends in the Nation's rivers and streams, 1972-2012-Data preparation, statistical methods, and trend results (ver. 2.0, October 2017): U.S. Geological Survey Scientific Investigations Report 2017-5006, 136 p., https://doi.org/10.3133/sir20175006.

Opsahl, S.P., Musgrove, MaryLynn, and Slattery, R.N., 2017, Continuous monitoring and discrete water-quality data from groundwater wells in the Edwards aquifer, Texas, 2014-15: U.S. Geological Survey data release, https://doi.org/10.5066/F7Q23XC2.

PASCO Scientific, 2015, Optical dissolved oxygen sensor PS-2196 instruction manual: Roseville, California, PASCO Scientific, 15 p., accessed June 16, 2018, at https://www.pasco.com/file_downloads/Downloads Manuals/PASPORT-Optical-Dissolved-Oxygen-SsnsorManual-PS-2196.pdf.

Pellerin, B.A., Downing, B.D., Kendall, C., Dahlgren, R.A., Kraus, T.E., Saraceno, J.F., Spencer, R.G.M., and Bergamaschi, B.A., 2009, Assessing the sources and magnitude of diurnal nitrate variability in the San Joaquin River (California) with an in situ optical nitrate sensor and dual nitrate isotopes: Freshwater Biology, v. 54, p. 376-387, accessed July 10, 2018, at https://onlinelibrary.wiley.com/ doi/epdf/10.1111/j.1365-2427.2008.02111.x.

Pellerin, B.A., Bergamaschi, B.A., Downing, B.D., Saraceno, J.F., Garrett, J.A., and Olsen, L.D., 2013, Optical techniques for the determination of nitrate in environmental waters - Guidelines for instrument selection, operation, deployment, maintenance, quality assurance, and data reporting: U.S. Geological Survey Techniques and Methods 1-D5, 37 p., accessed September 28, 2017, at https://pubs.usgs.gov/tm/01/d5/pdf/tm1d5.pdf.

Powell, R.M. and Puls, R.W., 1993, Passive sampling of groundwater monitoring wells without purging-Multilevel well chemistry and tracer disappearance: Journal of Contaminant Hydrology, v. 2, no. 12, p. 51-77, accessed July 2, 2018, at https://www.sciencedirect.com/science/ article/pii/016977229390015K.

RBR Limited, 2016, Multi-channel logger (3-13) Fact Sheet: Ottawa, Ontario, Canada, RBR Limited, 2 p., accessed November 22, 2017, at http://rbr-global.com/wp-content/ uploads/2017/02/RBRmaestro-0000614revD.pdf.
Ritz, G.F., and Collins, J.A., eds., 2008, pH (version 2.0): U.S. Geological Survey Techniques of Water-Resources Investigations, book 9, chap. A6, section 6.4, 30 p., accessed October 25, 2017, at http://pubs.water.usgs.gov/twri9A6/.

Ronen, D., Magaritz, M., and Levy, I., 1987, An in situ multilevel sampler for preventive monitoring and study of hydrochemical profiles in aquifers: Groundwater Monitoring \& Remediation Fall 1987, no. 4, p. 69-74, accessed July 2, 2018, at https://doi.org/10.1111/j.1745-6592.1987.tb00965.x.

Rounds, S.A., Wilde, F.D., and Ritz, G.F., eds., 2013, Dissolved oxygen (version 3.0): U.S. Geological Survey Techniques of Water-Resources Investigations, book 9, chap. A6, section 6.2, 55 p., accessed September 28, 2017, at http://pubs.water.usgs.gov/twri9A6/.

Rowe, G.L., Jr., Belitz, K., Essaid, H.I., Gilliom, R.J., Hamilton, P.A., Hoos, A.B., Lynch, D.D., Munn, M.D., and Wolock, D.W., 2010, Design of cycle 3 of the National Water-Quality Assessment Program, 20132023 - Part 1-Framework of water-quality issues and potential approaches: U.S. Geological Survey Open-File Report 2009-1296, 54 p.

Rowe, G.L., Jr., Belitz, K., Demas, C.R., Essaid, H.I., Gilliom, R.J., Hamilton, P.A., Hoos, A.B., Lee, C.J., Munn, M.D., and Wolock, D.W., 2013, Design of cycle 3 of the National Water-Quality Assessment Program, 2013-23Part 2-Science plan for improved water-quality information and management: U.S. Geological Survey Open-File Report 2013-1160, 110 p., http://pubs.usgs.gov/of/2013/1160/.

Sakamoto, C.M., Johnson, K.S., and Coletti, L.J., 2009, Improved algorithm for the computation of nitrate concentrations in seawater using an in situ ultraviolet spectrophotometer: Limnology and Oceanography Methods, v. 7, no. 1, p. 132-143, accessed December 18, 2017, at https://doi.org/10.4319/lom.2009.7.132.

Saraceno, J.F., Kulongoski, J.T., and Mathany, T.M., 2018, A novel high-frequency groundwater-quality monitoring system: Environmental Monitoring and Assessment, v. 190, no. 477, 14 p., https://doi.org/10.1007/s10661-018-6853-6.

U.S. Geological Survey, 2000, Ground Water Atlas of the United States: accessed March 30, 2018, at https:/pubs.usgs.gov/ha/ha730/gwa.html.

U.S. Geological Survey, 2006, Scientific Records Disposition Schedule 432-1-S2: U.S. Geological Survey-Water Resources Discipline web page, accessed May 13, 2018, at https://www2.usgs.gov/usgs-manual/schedule/432-1-s2/ index.html. 
U.S. Geological Survey, 2010, Continuous records processing of all water time series data: U.S. Geological Survey WaterResources Division Policy Memorandum No. 2010.02, accessed March 30, 2018, at https://water.usgs.gov/admin/ memo/policy/wrdpolicy10.02.html.

U.S. Geological Survey, 2012, Policy for release of continuous water-temperature data recorded from secondary sensors at streamgages and wells: U.S. Geological Survey Office of Water Quality Technical Memorandum No. 2012.02, accessed April 1, 2019, at https://water.usgs.gov/admin/ memo/QW/qw12.02.html.

U.S. Geological Survey, 2014, USGS Guidelines for the preservation of digital scientific data: U.S. Geological Survey, Office of Data Management web page, accessed April 11, 2018, at https:/www2.usgs.gov/datamanagement/ documents/USGS $\% 20$ Guidelines $\% 20$ for $\% 20$ the $\% 20$ Preservation \%20of\%20Digital\%20Scientific\%20Data\%20 Final.pdf.

U.S. Geological Survey, 2017a, Procedures for processing, approving, publishing, and auditing time-series records for water data: U.S. Geological Survey Office of Water Quality Technical Memorandum No. 2017.07, accessed August 28, 2017, at https://water.usgs.gov/admin/memo/ QW/qw2017.07.pdf.

U.S. Geological Survey, 2017b, Procedures for identifying and documenting revisions to USGS water data: U.S. Geological Survey Office of Water Quality Technical Memorandum No. 2017.03, https:/water.usgs.gov/admin/memo/QW/qw2017.03.pdf.

U.S. Geological Survey, 2017c, Clarification of water mission area policy on continuous records processing of time series data-Categorization of groundwater, surface water, and water-quality sites/records:

U.S. Geological Survey Office of Water Quality Technical Memorandum No. 2017.02, accessed March 3, 2017, at https://water.usgs.gov/admin/memo/QW/qw2017.02.pdf.

U.S. Geological Survey, 2019, Specific conductance: U.S. Geological Survey Techniques and Methods, book 9, chap. A6.3, 15 p., https://doi.org/10.3133/tm9A6.3. [Supersedes USGS Techniques of Water-Resources Investigations, book 9, chap. A6.3, version 1.2.]

VanMetre, P.C., and Journey, C.A., 2014, The southeast stream quality assessment: U.S. Geological Survey Fact Sheet 2014-3023, 2 p., https://doi.org/10.3133/fs20143023.
VanMetre, P.C., Frey, J.W., and Tarquinio, Ellen, 2012, The Midwest stream quality assessment: U.S. Geological Survey Fact Sheet 2012-3124, 2 p., https://doi.org/10.3133/fs20123124.

VanMetre, P.C., Morace, J.L., and Sheibley, Rich, 2015, The Pacific northwest stream quality assessment: U.S. Geological Survey Fact Sheet 2015-3020, 2 p., https://doi.org/10.3133/fs20153020.

Wagner, R.J., Boulger, R.W., Jr., Oblinger, C.J., and Smith, B.A., 2006, Guidelines and standard procedures for continuous water-quality monitors - Station operation, record computation, and data reporting: U.S. Geological Survey Techniques and Methods 1D3, 51 p. +8 attachments, accessed July 10, 2017, at http://pubs.water.usgs.gov/tm1d3.

Wilde, F.D., ed., 2006a, Collection of water samples (version 2.0): U.S. Geological Survey Techniques of Water-Resources Investigations, book 9, chap. A4, section 4.2.3, 5 p., accessed December 18, 2017, at http://pubs.water.usgs.gov/twri9A4/.

Wilde, F.D., ed., 2006b, Temperature (version 2):

U.S. Geological Survey Techniques of Water-Resources Investigations, book 9, chap. A6, section 6.1, 22 p., accessed September 28, 2017, at http://pubs.water.usgs.gov/twri9A6/.

Wilde, F.D., ed., variously dated, Field measurements (version 2.0): U.S. Geological Survey Techniques of Water-Resources Investigations, book 9, chap. A6, accessed December 18, 2017, at http://pubs.water.usgs.gov/twri9A6/.

Young, S.C. and Pearson, H.S., 1995, The electromagnetic borehole flowmeter - description and application: Ground Water Monitoring and Remediation Review, v. 15, no. 4, p. $138-147$.

YSI Incorporated, 2015, XL series user manual-Version 2.14: Yellow Springs, Ohio, YSI Incorporated, 184 p., accessed August 9, 2018, at https:/www.waterlog.com/media/pdfs/ xl-series-user-manual-(d41-02-0615).pdf.

YSI Incorporated, 2017, EXO pH sensor replacement module: Yellow Springs, Ohio, YSI Incorporated, accessed December 22, 2017, at https://www.ysi.com/Product/ id-599795-02/EXO-pH-Sensor-Replacement-Module. 


\section{Appendix 1. Water-Quality Sonde Characterization}

\section{Water-Quality Sonde Characterization Background}

Groundwater quality changes can be subtle and slowly varying. Even the slightest deviations caused by sensor calibration drift, inaccuracy, or maintenance visits can reduce the ability to detect meaningful variation in the groundwaterquality record. In terms of increased accuracy and precision, and lower detection limits, sensor technology has advanced in the years since U.S. Geological Survey (USGS) Techniques and Methods Report 1-D3 (Wagner and others, 2006) was published with minimum guidelines for water-quality sensor recalibration and data-correction thresholds. Specific guidance on sensor recalibration and data-correction thresholds for subtly varying high-frequency groundwater-quality data was unavailable at the time of writing this report. Therefore, the stated sensor accuracy range was used (provided by the manufacturer and validated or modified through repeated testing [for example, Snazelle, 2015]) as the starting point for the process of establishing sensor recalibration and data-correction thresholds for groundwater-quality records. Previous guidance documents and experimental results establish and verify sensor accuracy, but they do not consider sensor precision, which is an important factor in selecting the most appropriate technology to monitor subtly varying high-frequency groundwater-quality data. To bridge this gap, and to complete the process of establishing reasonable sensor recalibration and data-correction thresholds over a range of groundwater environments, the authors conducted a series of experiments and data analysis to test, quantify, and verify the precision of specific electrical conductivity ( $\mathrm{SC}$ ), $\mathrm{pH}$, and dissolved oxygen (DO) sensors that are commonly used on three commercially available water-quality sonde platforms.

\section{Experimental Methodology}

Laboratory experiments and field water-quality data were used to establish the precision and repeatability of a measurement and to evaluate the stability of three waterquality sondes to determine their suitability for high-frequency groundwater-quality monitoring. Ideal characteristics of a high-frequency groundwater-quality sonde include high accuracy, precision, and stability. Although the YSI/Xylem ${ }^{\circledR}$ $\mathrm{EXO}^{\mathrm{TM}}$ was recently evaluated by the USGS for accuracy compared to several standards over a wide range of conditions (Snazelle, 2015) our laboratory experiments were meant to evaluate the precision of repeated measurements of calibration standard solutions under controlled, "field-like" pumping conditions. Field-like pumping conditions were mimicked by pumping calibration standards though the experimental system at a standard flow rate of 1-2 gallons per minute (gal $/ \mathrm{min}$ ) using a peristaltic pump (figs. 1-1 and 1-2). In addition to the appropriate gal/min, the peristaltic pump also adequately applied the same hydrostatic pressure on the sensors that is present during field deployment.

A YSI/Xylem EXO1 (hereinafter referred to as EXO1; YSI Incorporated, 2019), a Eureka Water Probes ${ }^{\circledR}$ Manta 2 (hereinafter referred to as Manta 2; Eureka Environmental Engineering, 2016), and an RBR Maestro Multi-Channel Logger (hereinafter referred to as RBRmaestro; RBR Limited, 2016) were evaluated in side-by-side experiments using manufacturer supplied flow cells. The Manta 2 and EXO1 were equipped with three manufacturer supplied sensors, a combination temperature/SC sensor, a $\mathrm{pH}$ sensor, and a DO sensor. The RBRmaestro was equipped with a combination of manufacturer supplied and third-party sensors. The manufacturer included separate temperature (thermistor) and $\mathrm{SC}$ sensors. The SC sensor is a unique design that operates on the principle of speed of sound in water (RBR Limited, 2016). The third-party sensors included an IDRONAUT pH electrode with separate IDRONAUT reference electrode (IDRONAUT, 2019) and an Aanderaa ${ }^{\circledR}$ optical DO sensor (Xylem Incorporated, 2016).

The laboratory experiments quantified individual sensor precision by sequentially measuring $\mathrm{SC}$ and $\mathrm{pH}$ calibration standards and DO concentrations in a standard glass beaker inside a temperature-controlled water bath over a period of several hours (figs. 1-1 and 1-2). The experiment was not replicated because of laboratory time limitations during the testing period. Water bath temperature was verified with a National Institute of Standards and Technology traceable thermometer and was kept at $\left(25 \pm 1\right.$ degree Celsius $\left.\left[{ }^{\circ} \mathrm{C}\right]\right)$ during the experiment and water was continuously circulated using a peristaltic pump. The sonde measurements were taken hourly and operated in burst mode (if available) as described in table 1-1. The median of the burst measurements was used as the single-point hourly value in the calculation of sensor precision and on any plots of experimental time-series data.

\section{Electrical Conductivity Sensor Precision}

The electrical conductivity sensor precision experiment was done over a 33-hour period in a SC standard of 1,000 microsiemens per centimeter at $25^{\circ} \mathrm{C}\left(\mu \mathrm{S} / \mathrm{cm}\right.$ at $25^{\circ} \mathrm{C}$; Mathany and Saraceno, 2019). Although the sensors measure electrical conductivity, the data are reported in units of specific conductance to achieve comparability across a temperature range (Miller and others, 1988). To try to reduce potential evaporation effects, the beaker holding the conductivity standard solution was sealed with PARAFILM ${ }^{\circledR}$ paraffin film. The RBRmaestro could not be user calibrated at the time of use, therefore, the experiment proceeded with uncalibrated sensors. Uncalibrated sensors were not considered to be a problem, because the experiment sought to quantify sensor precision, not accuracy, through examining the degree of relative variability around the mean value. 


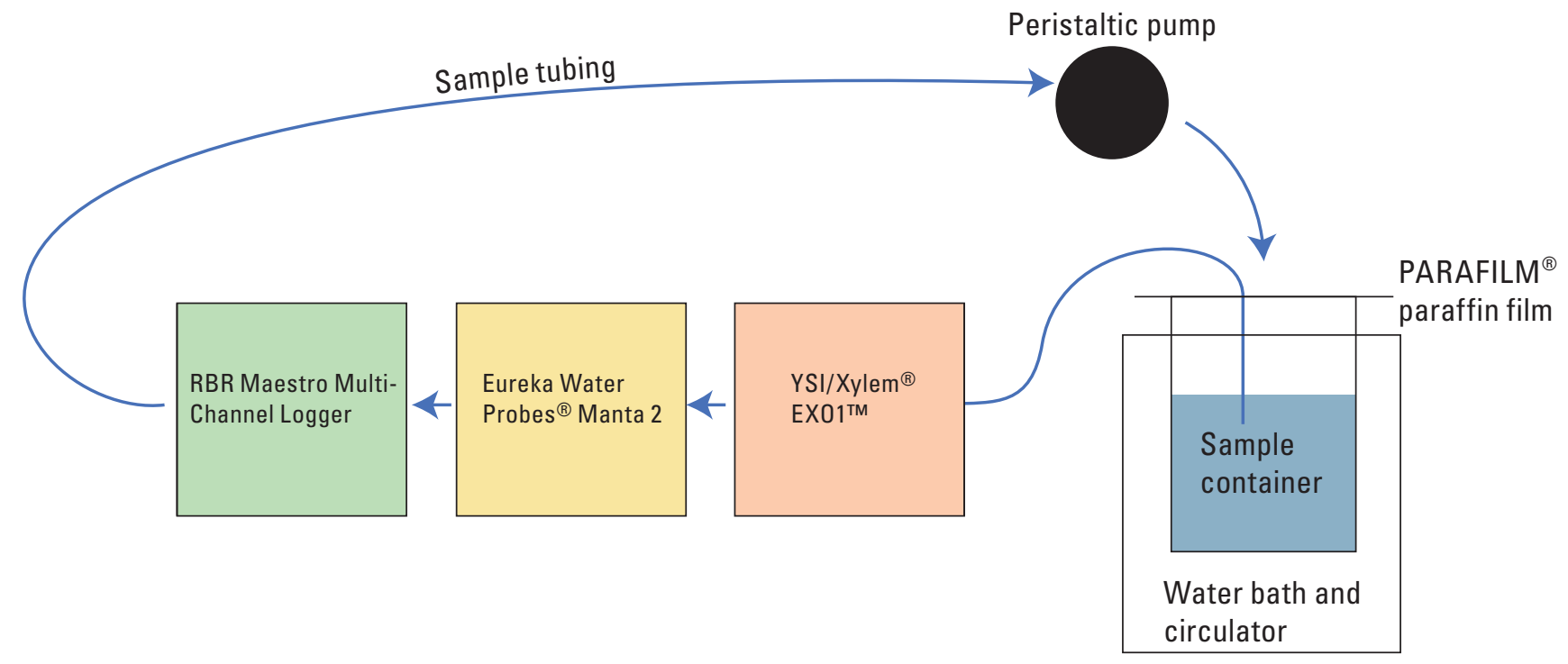

Figure 1-1. Laboratory experiment setup.

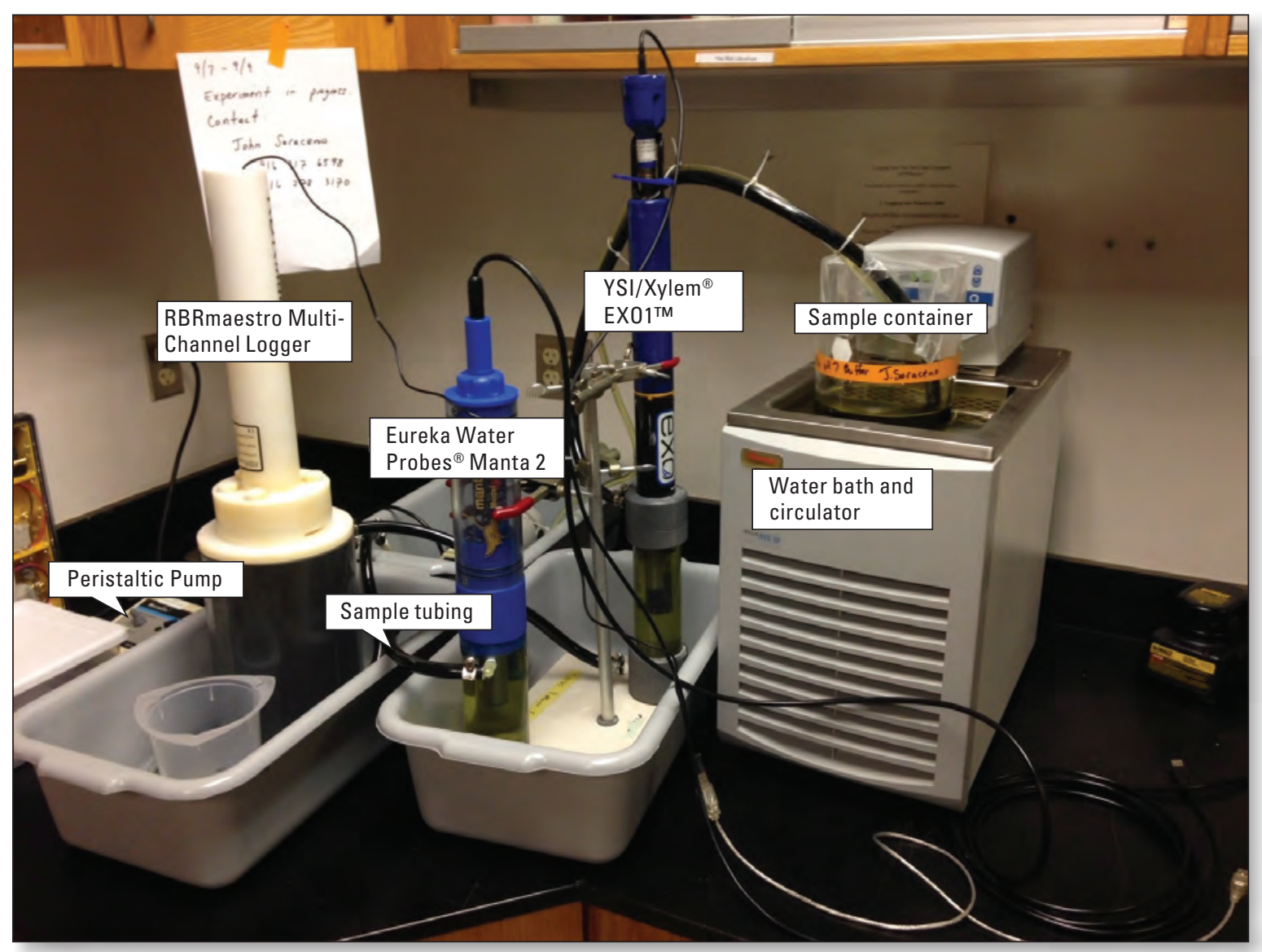

Photograph by John Franco Saraceno, U.S. Geological Survey.

Figure 1-2. Laboratory experiment setup. 
Table 1-1. Sonde measurement settings during laboratory experiments.

[Hz, hertz; na, not available]

\begin{tabular}{lccc}
\hline \multicolumn{1}{c}{ Sonde } & $\begin{array}{c}\text { Sample } \\
\text { interval }\end{array}$ & $\begin{array}{c}\text { Sample } \\
\text { burst } \\
\text { frequency }\end{array}$ & $\begin{array}{c}\text { Number } \\
\text { of burst } \\
\text { samples }\end{array}$ \\
\hline YSI/Xylem EXO1 & Hourly & $1 \mathrm{~Hz}$ & 60 \\
$\begin{array}{l}\text { RBR Maestro Multi-Channel } \\
\text { Logger }\end{array}$ & Hourly & $4 \mathrm{~Hz}$ & 512 \\
$\begin{array}{l}\text { Eureka Water Probes } \\
\text { Manta 2 }\end{array}$ & Hourly & na & 1 \\
\hline
\end{tabular}

During the experiment, there was an increasing linear trend in conductivity (fig. 1-3). The trends were similar in magnitude $\left(0.18-0.23 \mu \mathrm{S} / \mathrm{cm}\right.$ at $25{ }^{\circ} \mathrm{C}$ per hour; Mathany and Saraceno, 2019) across all sensor types and was consistent with the process of evaporation (Shah, 1981). The PARAFILM paraffin film was not sealed as air tight as expected. Therefore, to estimate the instantaneous variability of conductivity around the mean value, all of the time-series data were linearly de-trended for the effect because of evaporation (fig. 1-4; Mathany and Saraceno, 2019).
We calculated short-term experimental precision for each electrical conductivity sensor by taking the standard deviation (SD) of the de-trended time-series data and multiplying it by three to establish a 3 -sigma SD value (table 1-2). We used a 3-sigma $\mathrm{SD}$ value (that is three times the $\mathrm{SD}$ ) as a conservative estimate of precision because there are currently no widely accepted standards for the reporting of water-quality sensor precision.

\section{pH Sensor Precision}

The $\mathrm{pH}$ sensor precision experiment was to be done over a 33-hour period in a $\mathrm{pH} 7$ buffer. During the experiment, DO could not be held at atmospheric saturation; therefore, we could not proceed with a DO precision test. To reduce the bias imparted by anoxic conditions on $\mathrm{pH}$ buffer stability, we limited our analysis of $\mathrm{pH}$ results to a period when DO concentrations remained greater than $8 \mathrm{mg} / \mathrm{L}$. Limiting our analysis period resulted in reducing the experimental dataset for $\mathrm{pH}$ to 12 or 13 hours (depending on $\mathrm{pH}$ sensor) from the initially planned 33 hours (Mathany and Saraceno, 2019). We calculated the short-term experimental precision for each $\mathrm{pH}$ sensor by using the same procedures outlined in the electrical conductivity sensor precision experiment. The 3-sigma SD values for each $\mathrm{pH}$ sensor are presented in table 1-2.

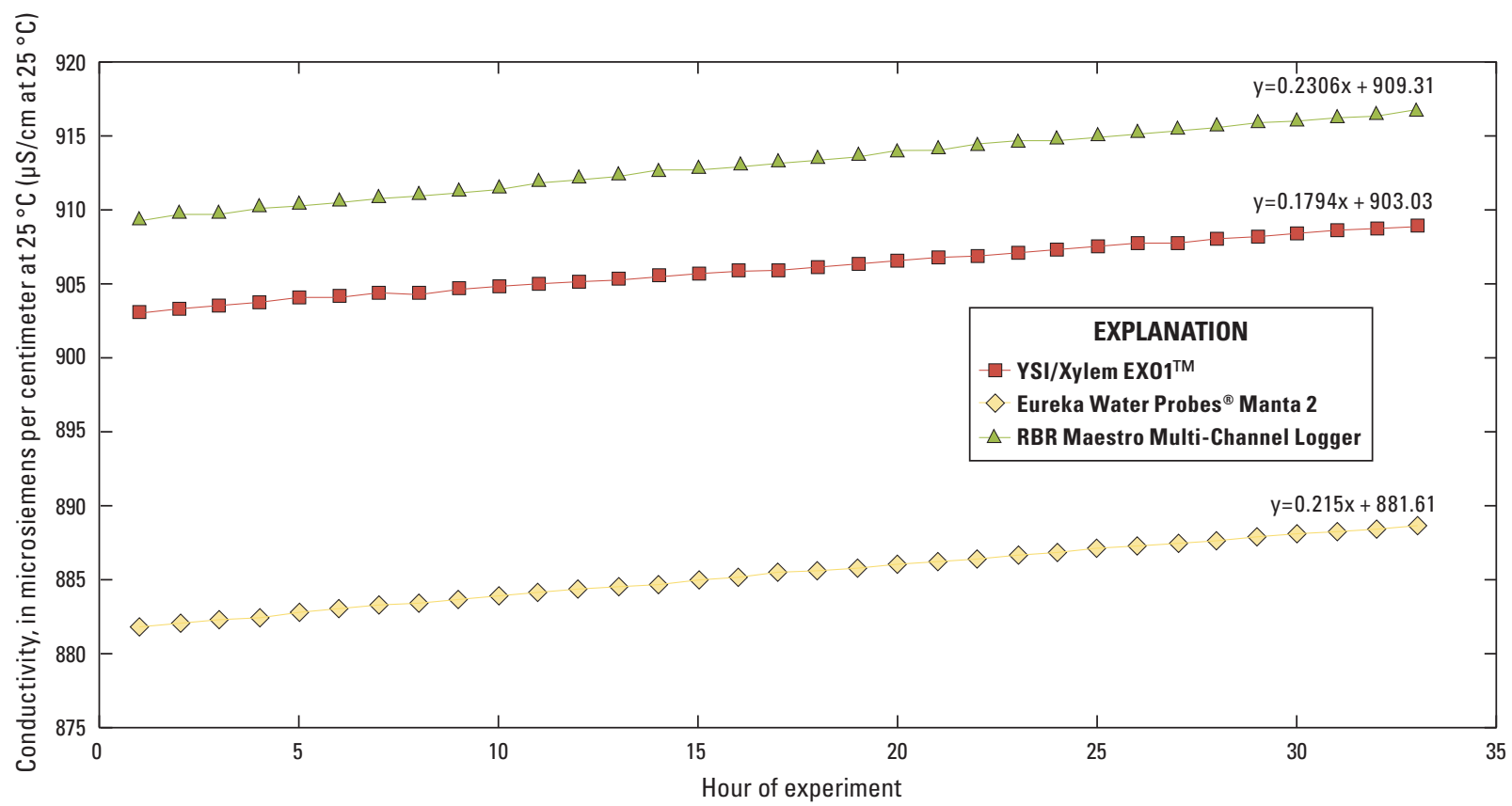

Figure 1-3. Specific conductance experiment time-series data. 


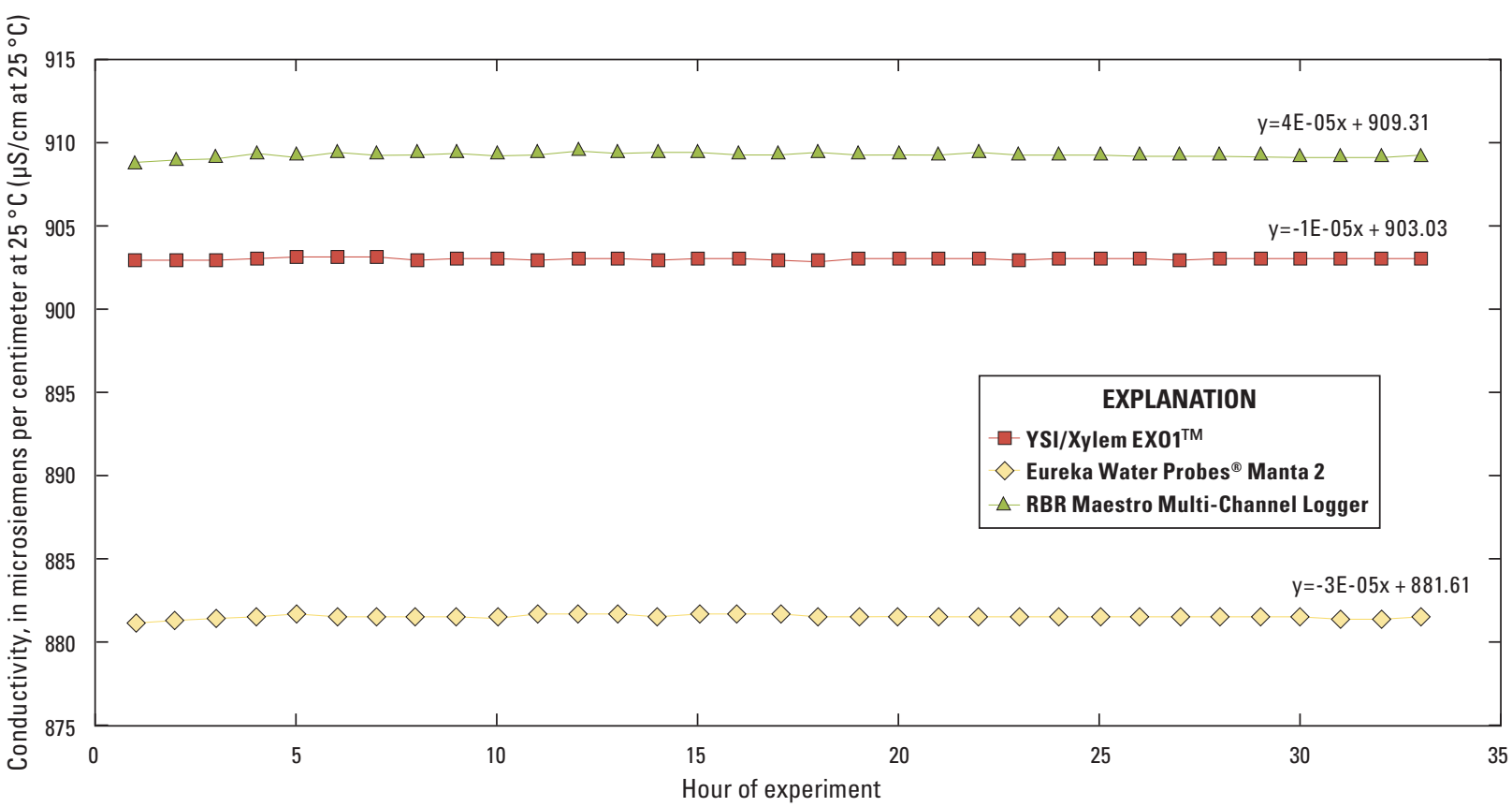

Figure 1-4. De-trended specific conductance experiment time-series data.

Table 1-2. Short-term and long-term precision of three water-quality sondes in $\mathrm{pH} 7$ and 1,000 microsiemens per centimeter ( $\mu \mathrm{S} / \mathrm{cm}$ ) calibration standards and from time-series data collected at high-frequency groundwater-quality station USGS 364200119420001 from September 2013 to October 2017.

[DO, dissolved oxygen; n, number; na, not available; RSD, relative standard deviation; SC, specific conductance; SD, standard deviation; USGS, U.S. Geological Survey; \%, percent; ${ }^{\circ} \mathrm{C}$, degrees Celsius; $\mu \mathrm{S} / \mathrm{cm}$, microsiemens per centimeter at $\left.25^{\circ} \mathrm{C}\right]$

\begin{tabular}{|c|c|c|c|c|c|c|c|c|c|c|}
\hline \multirow[b]{2}{*}{ Reference type } & \multirow{2}{*}{$\begin{array}{l}\text { Statistical } \\
\text { method } \\
\text { type }\end{array}$} & \multicolumn{3}{|c|}{ Xylem/YSI - EX01 sonde } & \multicolumn{3}{|c|}{ RBRmaestro sonde } & \multicolumn{3}{|c|}{ Eureka - Manta 2 sonde } \\
\hline & & (n) & $\begin{array}{l}\text { (1-sigma } \\
\text { precision) }\end{array}$ & $\begin{array}{l}\text { (3-sigma } \\
\text { precision) }\end{array}$ & (n) & $\begin{array}{l}\text { (1-sigma } \\
\text { precision) }\end{array}$ & $\begin{array}{l}\text { (3-sigma } \\
\text { precision) }\end{array}$ & (n) & $\begin{array}{l}\text { (1-sigma } \\
\text { precision) }\end{array}$ & $\begin{array}{l}\text { (3-sigma } \\
\text { precision) }\end{array}$ \\
\hline $1,000 \mu \mathrm{S} / \mathrm{cm}$ SC standard & SD & 33 & 0.19 & 0.57 & 33 & 0.24 & 0.73 & 33 & 0.24 & 0.72 \\
\hline $\begin{array}{l}1,000 \mu \mathrm{S} / \mathrm{cm} \text { SC standard } \\
\quad(\text { detrended })^{1}\end{array}$ & SD & 33 & 0.07 & 0.20 & 33 & 0.15 & 0.45 & 33 & 0.12 & 0.36 \\
\hline \multicolumn{11}{|c|}{ USGS well 364200119420001} \\
\hline $\mathrm{SC}$ & RSD & 46,053 & $0.3 \%$ & $1.0 \%$ & 1,394 & $0.6 \%$ & $1.9 \%$ & na & na & na \\
\hline $\mathrm{pH}$ & RSD & 47,599 & $0.4 \%$ & $1.3 \%$ & 1,323 & $1.1 \%$ & $3.3 \%$ & na & na & na \\
\hline DO & RSD & 52,895 & $2.6 \%$ & $7.8 \%$ & 1,394 & $8.0 \%$ & $24.0 \%$ & na & na & na \\
\hline
\end{tabular}

${ }^{1}$ To examine and compare the variability around the mean, the SC time series was linearly detrended for the effect due to evaporation (Shah, 1981). 


\section{Long-Term Field Precision Analysis}

Following the short-term precision experiments, we examined the long-term precision of $\mathrm{SC}, \mathrm{pH}$, and DO sensors by analyzing the groundwater-quality timeseries data generated at a deep municipal supply well (USGS station 364200119420001) during the period from September 2013 to July 2018. Station 364200119420001 is monitoring the Central Valley Aquifer for the National Water Quality Program Enhanced Trends Network and is known to have stable water-quality field parameters based on variance calculations on the complete USGS National Water Information System-Time Series database record for SC, $\mathrm{pH}$, and DO (from September 2013 to July 2018) and comparisons between several years of concurrent field parameter readings during bi-monthly discrete sample collection (https://nwis.waterdata.usgs.gov/usa/nwis/qwdata/?site no $=364200119420001 \&$ \&agency cd $=$ USGS) (Saraceno and others, 2018).

The EXO1 was deployed from September 2013

to July 2018 and collected data every 15 minutes (https://nwis.waterdata.usgs.gov/nwis/ $\mathrm{uv} /$ ?site no $=364200119420001 \&$ PARAmeter $\mathrm{cd}=00095,00010,00300,00400$ ), whereas the RBRmaestro was deployed from February 2016 to June 2016 and September 2017 to October 2017 and collected data every two hours (Mathany and Saraceno, 2019). The Manta 2 was not part of the long-term field precision analysis because it was returned to the manufacturer under a limited time commitment just after the completion of the short-term precision experiments in the laboratory.

Because of the considerable amount of water-quality data collected over a 5-year period, relative standard deviation (RSD) was selected as the appropriate statistical method for the long-term precision analysis of the water-quality sensors. The RSD of the resulting time-series data was calculated (and multiplied by 100 to get a percentage) and then multiplied by three to establish the 3-sigma RSD, long-term measurement precision for each water-quality sensor (table 1-2).

\section{Results of the Water-Quality Sonde Characterization}

The results of the short-term laboratory precision experiments of the three water-quality sondes for both $\mathrm{SC}$ and $\mathrm{pH}$ are presented in table $1-2$. For the detrended $1,000 \mu \mathrm{S} / \mathrm{cm}$ at $25{ }^{\circ} \mathrm{C} \mathrm{SC}$ standard precision experiment $(\mathrm{n}=33)$ the EXO1 had the smallest 3-sigma SD at $0.20 \mu \mathrm{S} / \mathrm{cm}$ at $25^{\circ} \mathrm{C}$, with the Manta 2 and RBRmaestro having a larger 3-sigma SDs at $0.36 \mu \mathrm{S} / \mathrm{cm}$ at $25^{\circ} \mathrm{C}$ and $0.45 \mu \mathrm{S} / \mathrm{cm}$ at $25^{\circ} \mathrm{C}$, respectively. The results for the $\mathrm{pH}$ precision experiment $(\mathrm{n}=12$ or 13) showed low 3-sigma SDs for each of the water-quality sondes (table 1-2). The Manta 2 had the smallest 3-sigma SD at $0 \mathrm{pH}$ units, followed by the EXO1 at $0.02 \mathrm{pH}$ units, and the RBRmaestro at $0.06 \mathrm{pH}$ units.

The long-term field precision analysis of the waterquality data generated by the EXO1 and the RBRmaestro resulted in varying levels of similarities between the 3-sigma RSDs for $\mathrm{SC}, \mathrm{pH}$, and DO (table 1-2). For the SC data, the EXO1 $(n=46,053)$ had a 3-sigma RSD of 1.0 percent, similarly, the 3-sigma RSD for the RBRmaestro $(n=1,394)$ was 1.9 percent. The $\mathrm{pH}$ sensors showed a larger difference than the SC sensors, with the EXO1 $\mathrm{pH}$ data $(\mathrm{n}=47,599)$ having a 3-sigma RSD of 1.3 percent, and the RBRmaestro (n $=1,323$ ) a 3 -sigma RSD of 3.3 percent. The DO data showed the greatest difference between the EXO1 and RBRmaestro, with the EXO1 $(\mathrm{n}=52,895)$ having a 3-sigma RSD of 7.8 percent and the RBRmaestro $(n=1,394) 3$-sigma RSD equaling 23.9 percent.

The results of the water-quality sonde characterization experiments indicated that the short- and long-term precision of the sensors are in line with the technical information provided by the manufacturers. Field and office personnel are encouraged to perform their own water-quality sonde characterization experiments, and to use the water-quality sonde information provided in this report as a layer of evidence that modern water-quality sensors are performing as stated by the manufacturer and at a level of precision greater than the sensor recalibration and data-correction guidelines presented in Wagner and others (2006), suggesting the timeliness of updated guidelines to reflect the latest technological advances. 


\section{References Cited}

Eureka Environmental Engineering, 2016, Manta 2 Water Quality Multiprobe Manual: 51 p., accessed October 19, 2017, at http://www.rshydro.co.uk/PDFs/Eureka/Manta2manual.pdf.

IDRONAUT, 2019, pH Sensor (Glass) (700 bar) and Reference Solid Gel Sensor (KCl) (700 bar): IDRONAUT Ocean Seven 310, Operators Manual: Brugherio, Italy, 139 p., accessed August 12, 2019, at https://www.idronaut.it/Download/Documentation/ Product\%20Manuals/OceanSeven310_OperatorManual.pdf.

Mathany, T.M., and Saraceno, J.F., 2019, Electrical conductivity, $\mathrm{pH}$, and dissolved oxygen time-series data generated from the short-term precision experiment and the long-term field precision analysis to characterize waterquality sondes for the Guidelines and Standard Procedures for High-Frequency Groundwater-Quality Monitoring Station Techniques and Methods Report: U.S. Geological Survey data release, https://doi.org/10.5066/P9QLWSBS.

Miller, R.L., Bradford, W.L., and Peters, N.E., 1988, Specific conductance-Theoretical considerations and application to analytical quality control: U.S. Geological Survey WaterSupply Paper 2311, 23 p., https://doi.org/10.3133/wsp2311.

RBR Limited, 2016, Multi-channel logger (3-13) Fact Sheet: Ontario, Canada, RBR Limited, 2 p., accessed November 22, 2017, at http://rbr-global.com/wp-content/ uploads/2017/02/RBRmaestro-0000614revD.pdf.
Saraceno, J.F., Kulongoski, J.T., and Mathany, T.M., 2018, A novel high-frequency groundwater-quality monitoring system: Environmental Monitoring and Assessment, v. 190, no. 477, 14 p., https://doi.org/10.1007/s10661-018-6853-6.

Shah, M.M., 1981, Estimation of evaporation from horizontal surfaces: American Society of Heating, Refrigerating and Air-Conditioning Engineers, v. 87, no. 1, p. 35-51.

Snazelle, T.T., 2015, Evaluation of Xylem EXO water-quality sondes and sensors: U.S. Geological Survey Open-File Report 2015-1063, 28 p., https://doi.org/10.3133/ofr20151063.

Wagner, R.J., Boulger, R.W., Jr., Oblinger, C.J., and Smith, B.A., 2006, Guidelines and standard procedures for continuous water-quality monitors-Station operation, record computation, and data reporting: U.S. Geological Survey Techniques and Methods 1D3, 51 p. +8 attachments, accessed July 10, 2017, at http://pubs.water.usgs.gov/tm1d3.

Xylem Incorporated, 2016, Aanderaa Oxygen Optode 4831/4831F: accessed August 10, 2018, at https://www.aanderaa.com/media/pdfs/oxygen-optode4831_4831f.pdf.

YSI Incorporated, 2019, EXO user manual—Advanced water quality monitoring platform, revision E: Yellow Springs, Ohio, YSI Incorporated, 156 p., accessed March 11, 2019, at https://www.ysi.com/File\%20Library/Documents/Manuals/ EXO-User-Manual-Web.pdf. 


\section{Appendix 2. U.S. Geological Survey High-Frequency Groundwater-Quality Field Form}

Appendix 2 consists of an .xls file available for download at https://doi.org/10.3133/tm1D7.

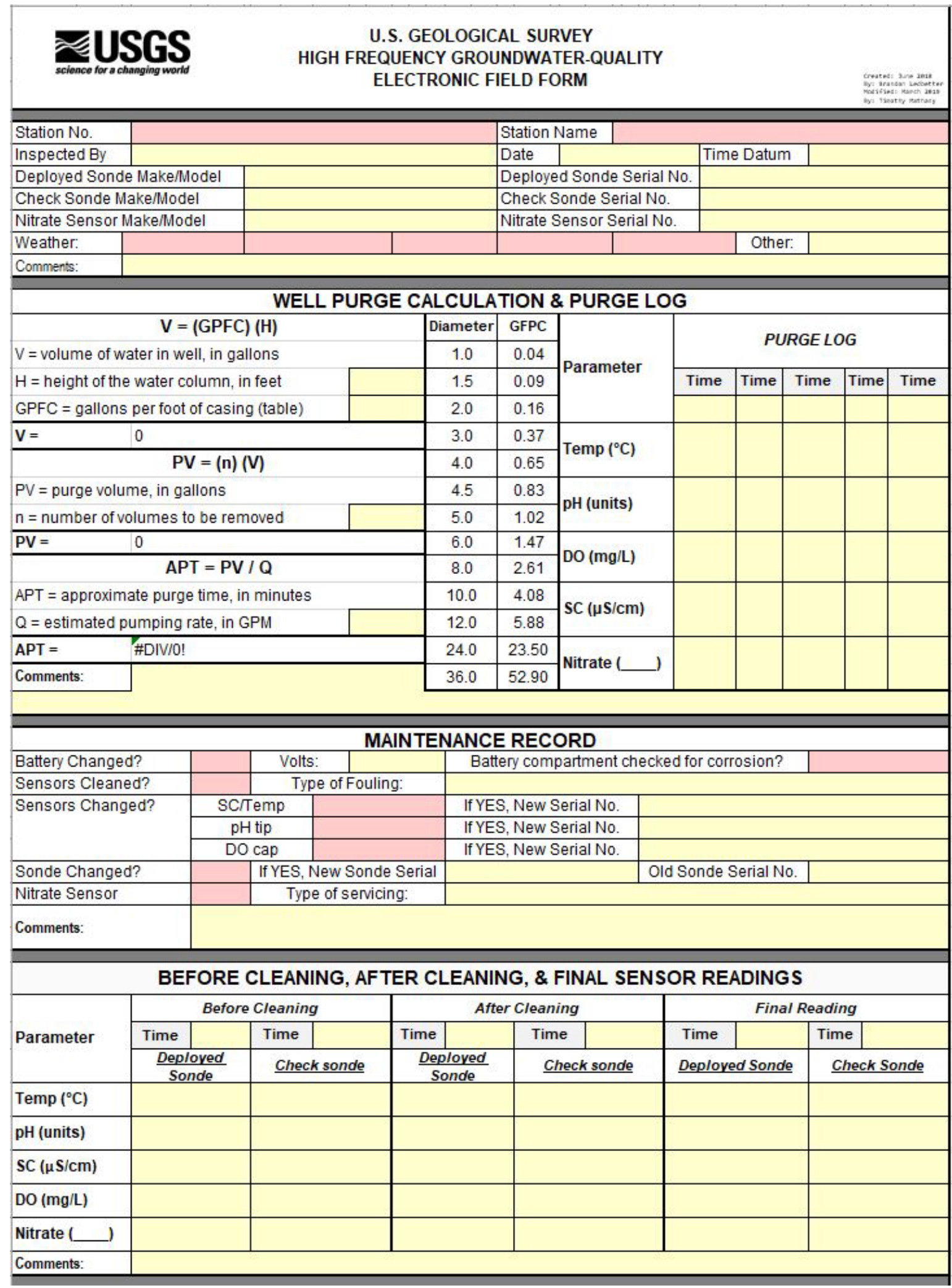




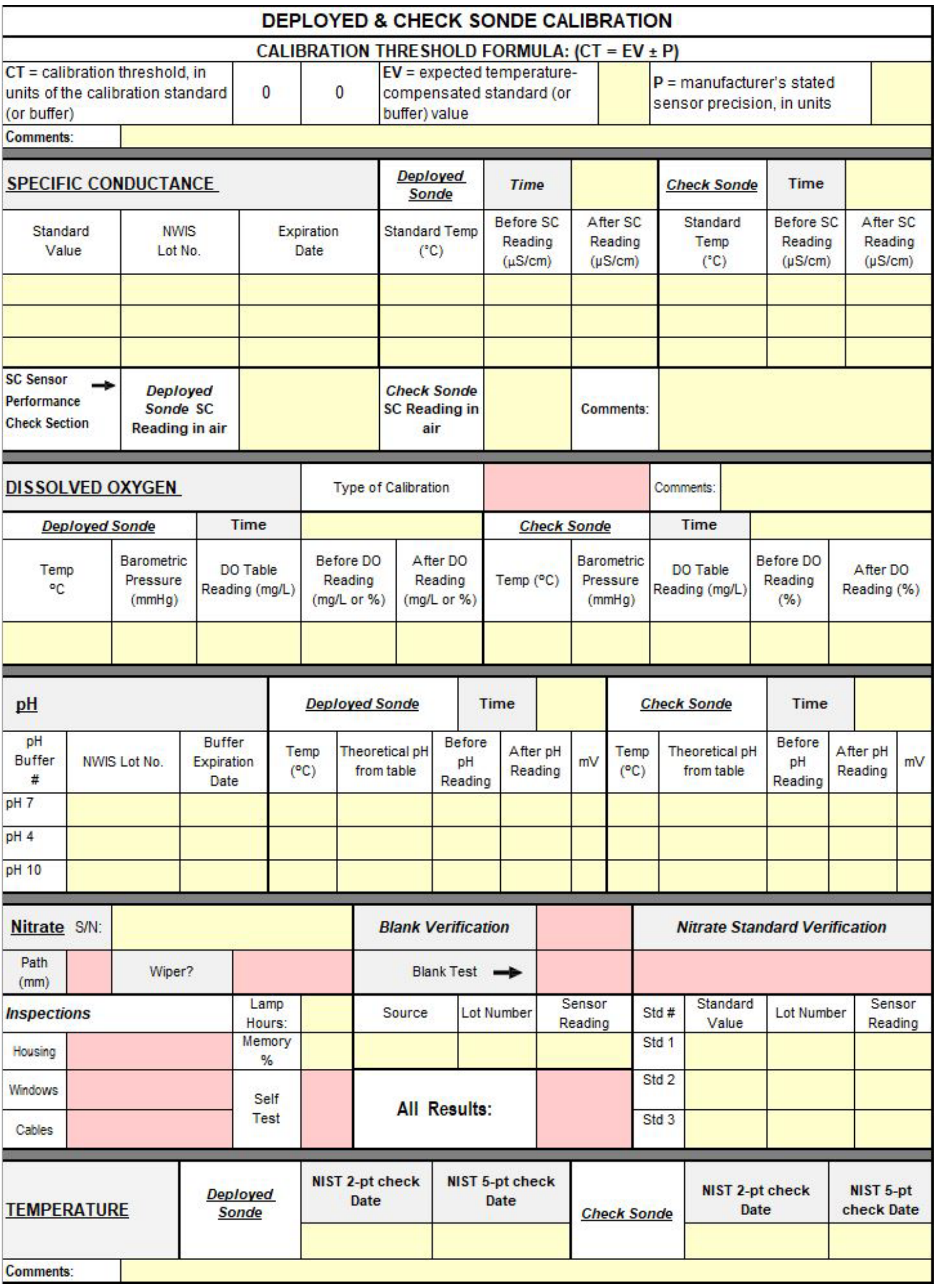




\section{Appendix 3. Example of a Station Description for a High-Frequency Groundwater-Quality Station}

$9 / 25 / 2018$

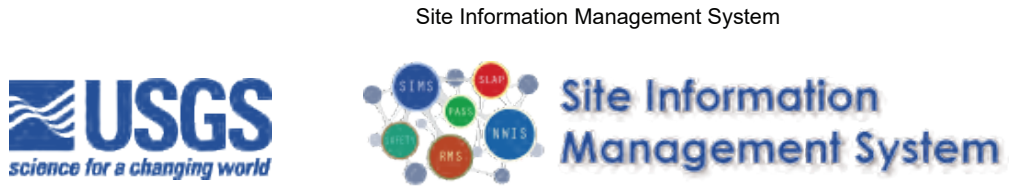

Station Documents

364200119420001 014S021E17Q001M
Responsible Office

U.S. Geological Survey San Diego - Projects Office 4165 Spruance Road, Suite 200 San Diego CA 92101-0812

(619) 222-2243

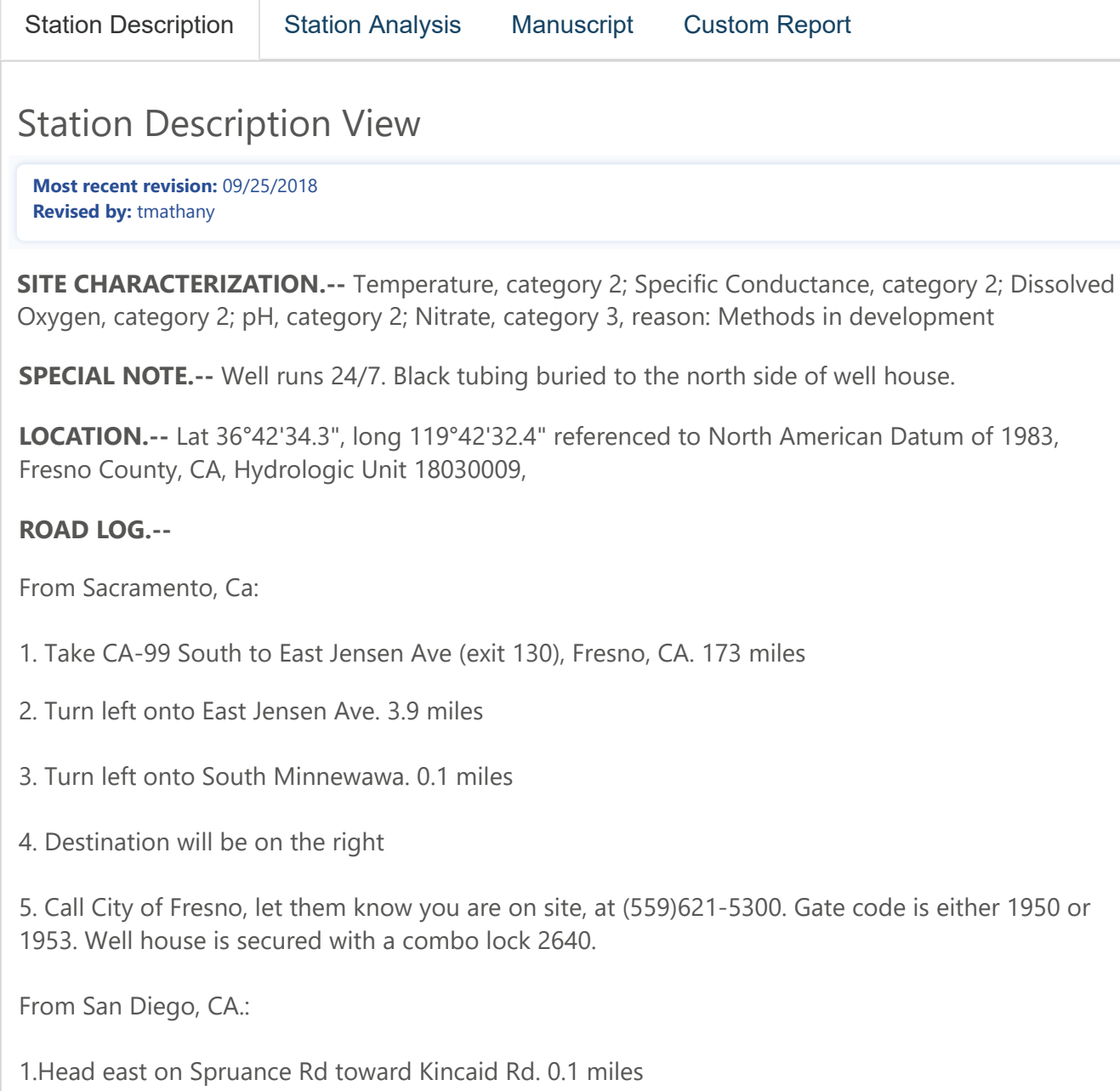


2.Take the 2nd right onto Mc Cain Rd. 0.2 miles

3. Take the 1 st right onto $\mathrm{N}$ Harbor Dr. 0.6 miles

4. Turn right onto Laning $\mathrm{Rd} 0.5$ miles

5. Turn right onto Rosecrans St 1.7 miles

6. Continue onto Camino Del Rio W 0.4 miles

7. Slight right to merge onto I-5 N toward Los Angeles. 113 miles

8. Keep right to stay on I-5 N, follow signs for I-10 W/Santa Monica/Interstate 5 N/Sacramento 87.6 miles

9. Continue onto CA-99 N (signs for California 99 N/Bakersfield/Fresno) to East Jensen Ave (exit 130), Fresno, CA. 123 miles

10. Turn right onto East Jensen Ave. 3.9 miles

11. Turn left onto South Minnewawa. 0.1 miles

12. Destination will be on the right

13. Call City of Fresno, let them know you are on site, at (559)621-5300. Gate code is either 1950 or 1953. Well house is secured with a combo lock 2640.

SITE HAZARD ANALYSIS.-- Review all pertinent CAWSC Job Hazard Analyses. Specifically, there is a fall risk when cleaning solar panels on roof of main enclosure or walking around onsite groundwater mixing stack located in the southeastern portion of well site. High-pressure water flowing through the municipal supply system is also a hazard to be noted. Black widows have been know to live in the well sheds. High-Voltage equipment is located in the main enclosure.

ESTABLISHMENT AND HISTORY.-- This well was built 11/16/1995 for the City of Fresno, by Myers Bros. Well Drilling Inc., to a depth of $620 \mathrm{ft}$. 14S/21E-17Q1m was established as a high-frequency groundwater-quality monitoring site by the U.S. Geological Survey in September 2013.

AQUIFER.-- Central Valley

WELL CHARACTERISTICS.-- Depth $620 \mathrm{ft}$. Upper casing diameter $14 \mathrm{in}$; top of first opening $410 \mathrm{ft}$, bottom of last opening $610 \mathrm{ft}$.

COOPERATION.-- Site 14S/21E-17Q1M is a production well owned by the city of Fresno. The site ID is 364200119420001 and Well\# 14S/21E-17Q1M. 
MAP.--

View Larger Map

DESCRIPTION OF EQUIPMENT.--

Instrumentation is located inside chain linked fenced "pump-house". YSI EXO1 multi-parameter instrument (temperature, specific conductance, $\mathrm{pH}$, and optical dissolved oxygen) is connected to a CSI CR1000 data-logger. The CR1000 data-logger records water quality data from the EXO sonde and transmits the data to the office via a Raven XT 3G modem.

Well water runs in underground black tubing from wells 180-1, 180-2, and 180-MW into a solenoid unit. The solenoid unit is used to regulate and direct flow from the wells to the sonde sensor housed inside a flow cell, and then water goes to a SUNA Nitrate Sensor. The solenoid unit allows for manually switching of well water to the sampling hose bib prior to collecting water quality data. Flow sensors are installed on solenoid unit for flagging data when sensors are not sampling flowing water (pumps off, click, break, etc.).

WATER QUALITY MEASUREMENTS.-- 180-1 and 180-2: 1) each hour the solenoid switches between wells at $+1 \mathrm{~min}, 2$ ) well is purged for $60 \mathrm{~min}, 3)$ one instantaneous EXO1 measurement is taken on the hour (180-1 = even hour and 180-2 = odd hour), and 4) transmitted to NWIS-TS. 180-MW: 1) well is sampled every 3rd day because of power needs, 2) well is purged for 60 min starting at 0910, then 3) measurements taken every min for $30 \mathrm{~min}$, and 4) transmitted to NWIS-TS.

U.S. Geological Survey, GS-W Help SIMS@usgs.gov, Page Last Updated: 08/30/2017 


\title{
Appendix 4. Example of a Station Analysis for a High-Frequency Groundwater- Quality Station
}

\author{
Station Analysis
}

364200119420001 014S021E17Q001M (180-1)

Specific Conductance (SC), microsiemens per centimeter $\left(\mu \mathrm{S} / \mathrm{cm} @ 25^{\circ} \mathrm{C}\right)$

The following days were placed in review: 01/27/2018 to 04/25/2018.

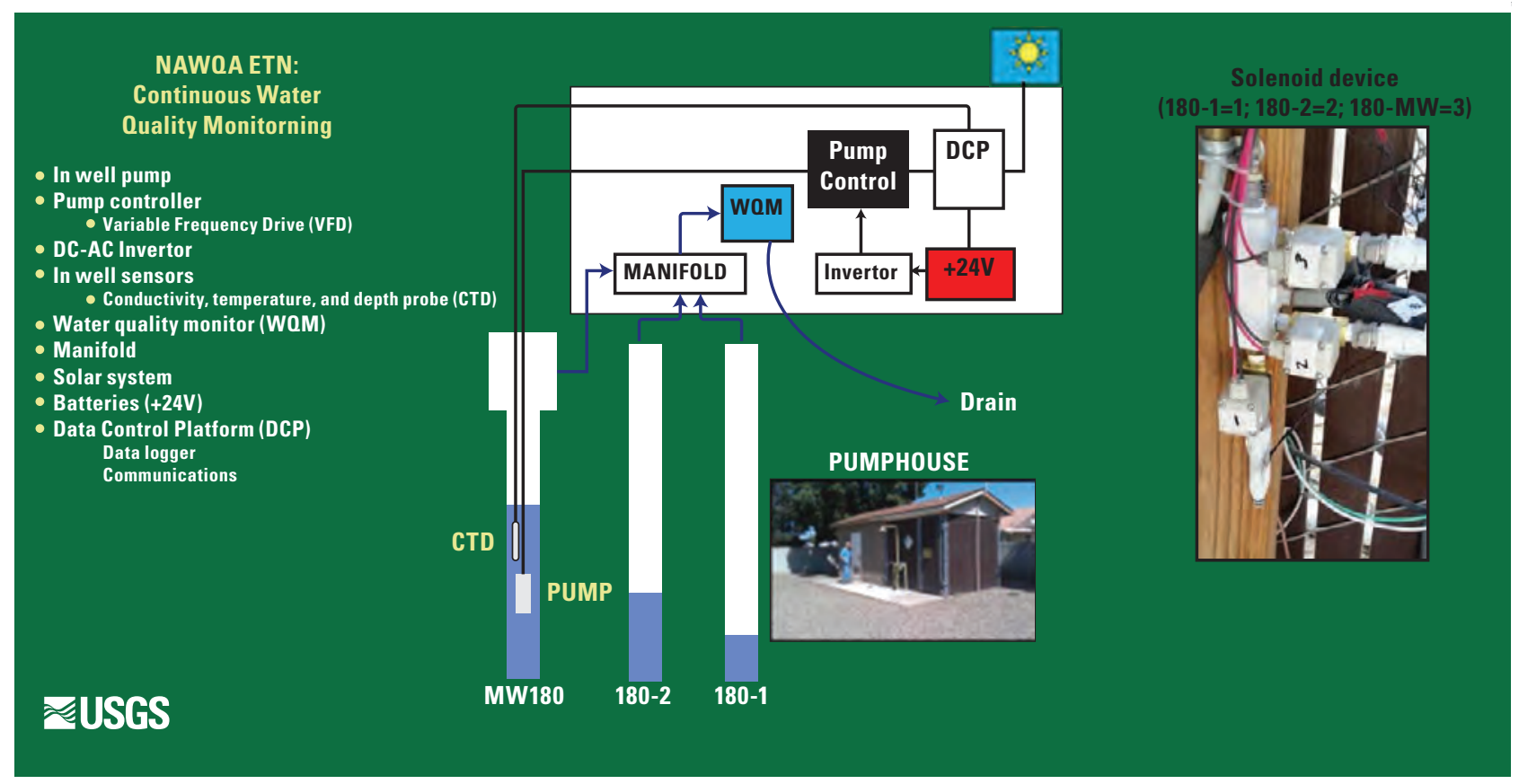

SAMPLING LOCATION:

LOCATION OF WELL CLUSTER: $36^{\circ} 42^{\prime} 34.9^{\prime \prime} \mathrm{N} 119^{\circ} 42^{\prime} 32.6^{\prime \prime} \mathrm{W}$ referenced to North American Datum of 1983, in Fresno County, CA, Hydrologic Unit 18030012. The well cluster is located off of S. Minnewawa. The cooperative program with City of Fresno water department requests bi-monthly water-quality samples.

Station Description found at: http://sims.water.usgs.gov/SIMS/StationDoc/ViewDocs.aspx? site_id=10000455\&type=SDESC

INTRUMENTATION: Instrumentation is located inside chain linked fenced "pump-house". YSI EXO1 multi-parameter instrument (temperature, specific conductance, $\mathrm{pH}$, and optical dissolved oxygen) is connected to a CSI CR1000 data-logger. The CR1000 data-logger records water quality data from the EXO sonde and transmits the data to the office via a Raven XT 3 G modem. Well water runs in underground black tubing from wells 180-1, 180-2, and 180$\mathrm{MW}$ into a solenoid unit. The solenoid unit is used to regulate and direct flow from the wells to the sonde sensor housed inside a flow cell, and then water goes to a SUNA Nitrate Sensor. The solenoid unit allows for manually switching of well water to the sampling hose bib prior to collecting water quality data. Flow sensors are installed on solenoid unit for flagging data when sensors are not sampling flowing water (pumps off, click, break, etc.). Changes/Modifications: There were no changes or modifications to the program from previous water year. 
GROUNDWATER-QUALITY RECORD: 180-1 and 180-2: 1) each hour the solenoid switches between wells at +1 min, 2) well is purged for $60 \mathrm{~min}, 3)$ one instantaneous EXO1 measurement is taken on the hour (180-1 = even hour and 180-2 = odd hour), and 4) transmitted to NWIS-TS. 180-MW: 1) well is sampled every 3rd day because of power needs, 2) well is purged for 60 min starting at 0910, then 3) measurements taken every min for 30 min, and 4) transmitted to NWIS-TS.

SITE VISITS: Three site visits occurred during the period of record: 1/25/2018, 3/14/2018, and 04/24/2018 Sonde calibration methods: EXO KOR Software is used to recalibrate EXO1 probes ( $\mathrm{pH}, \mathrm{DO}$, and SC) on all site visits. For SC, the SC probe is cleaned then calibrated to $1,000 \mu \mathrm{S}$ standard and checked with $500 \mu \mathrm{S}$ standard during every site visit.

DELETIONS: Total missing record for this period is 3 days (Pump off). Non-pumping times were on the following dates as recorded by the city of Fresno (site 180-01) and measured data during these periods have been removed: 2/26/2018 (19.4 hours), 2/28/2018 (21.6 hours), 3/2/2018 (22.9 hours).

Time-series thresholds-

NWIS-TS set to auto-remove ("X") all SC values $>408 \mu$ S and $<220 \mu$ S. Data thresholds set to flag all values $>390 \mu S$ and $<240 \mu \mathrm{S}$.

\section{FOULING ERROR CORRECTIONS:}

1/25/2018 @ 1215 to 03/14/2018 @ 1115 - USGS multi-point shift: Start point: (0 $\mu S, 0 \mu S)$ End point: $(0 \mu S, 0 \mu S$; $1.000 \mathrm{e}+05 \mu \mathrm{S}, 125.471 \mu \mathrm{S})$.

03/14/2018@ 1115 to 04/24/2018 @ 1406 - USGS multi-point shift: Start point: ( $0 \mu \mathrm{S}, 0 \mu \mathrm{S})$ End point: $(0 \mu \mathrm{S}, 0 \mu \mathrm{S}$; $1.000 \mathrm{e}+05 \mu \mathrm{S},-1320.755 \mu \mathrm{S})$.

04/24/2018 @ 1406 to 06/05/2018 @ 1053 - USGS multi-point shift: Start point: (0 $\mu \mathrm{S}, 0 \mu \mathrm{S})$ End point: $(0 \mu \mathrm{S}, 0 \mu \mathrm{S}$; $1.000 \mathrm{e}+05 \mu \mathrm{S},-62.952 \mu \mathrm{S})$.

CALIBRATION DRIFT CORRECTIONS:

11/25/2018 @ 1250 to 03/14/2018 @ 1200 - USGS multi-point shift: Start point: (0 $\mu S, 0 \mu S)$ End point: $(0 \mu S, 0 \mu S$; $1.000 \mathrm{e}+05 \mu \mathrm{S}, 90.081 \mu \mathrm{S})$.

03/14/2018 @ 1200 to 04/24/2018 @ 1530 - USGS multi-point shift: Start point: $(0 \mu \mathrm{S}, 0 \mu \mathrm{S})$ End point: $(1004.6 \mu S$, $-4.6 \mu \mathrm{S})$.

04/24/2018 @ 1530 to 06/05/2018 @ 1120 - USGS multi-point shift: Start point: (0 $\mu \mathrm{S}, 0 \mu \mathrm{S})$ End point: $(0 \mu \mathrm{S}, 0 \mu \mathrm{S}$; $1.000 \mathrm{e}+05 \mu \mathrm{S}, 358.357 \mu \mathrm{S})$.

\section{OTHER DATA CORRECTIONS:}

None.

\section{REMARKS}

SC tended to stay in-between 316-320 $\mu$ S. 


\section{Appendix 5. Example of a High-Frequency Groundwater-Quality Record Analyst Checklist}

Appendix 5 is a .PDF file available for download at https://doi.org/10.3133/tm1D7.

\section{Checklist for the High frequency Groundwater-Quality Record Analyst}

This is a suggested checklist to be used when analyzing a groundwater-quality record. Feel free to modify these guidelines in consultation with the project manager or section supervisor.

Site Name: Site ID:

Parameter: Year (water/calendar):

Worked by: Date: Analyzed by: Date:

With the project manager and/or the section supervisor, discuss the project's data-quality objectives and set time limits for analyzing the record. (Recommendations listed below)

Time limits: minutes for the field sheets ( $\leq 10$ minutes per record) minutes for checking shift tables and spreadsheets ( $\leq 20$ minutes) minutes for the entire record ( $\leq 90$ minutes)

Yes|No If field sheets are to be checked, include the following in your analysis:

$\square$ Probes were calibrated properly.

All appropriate information included.

Any changes in procedure over the course of the year noted and justified

Examine a graph of the raw and corrected data, including marks that coincide with site visits. Use the station analysis as a guide, and look for:

\section{Data gaps}

Spikes in the data that exceed the project's criteria for deletion

Obvious probe failures

Expected patterns in the data (annual, daily, and those due to site specific conditions)

Shift implementation - look for the size of shifts by comparing raw and corrected data

Discontinuities (step functions) in the raw data at site visits. If present at a level that exceeds the accuracy of the probe, suggest a solution to eliminate the discontinuity.

Examine other plots of the data provided by the field personnel. If necessary, create additional plots of the data showing comparisons to other constituents at this site.

Check for consistency in the data patterns. If inconsistencies are present, suggest an appropriate course of action to remove the inconsistency or explain its presence.

Yes|No If correction processes are to be analyzed, include the following in your analysis:

$\square$ Transcription errors from field sheets to correction spreadsheets

Transcription errors from correction spreadsheets to NWIS-TS fields

Missing or inappropriate shifts, not noted in correction spreadsheet or station analysis?

Shifts that do not cover the entire range of the data

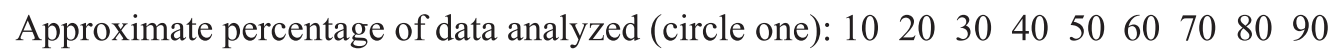
all 
The record has been analyzed! Notify the field personnel if changes are needed to the record. Otherwise, the record can now be sent to the designated approver.

In NWIS-TS, make sure data is put into "Analyzed" status before sending to approval.

Total time needed to analyze the record: hours

$\square$ If the time exceeded the time limit established at the top of this checklist, meet with the project manager to determine how the process might be further streamlined.

After completing this checklist, put it in the record's folder.

Analyst Comments: 


\section{Appendix 6. Example of a High-Frequency Groundwater-Quality Record Approver Checklist}

Appendix 6 is a .PDF file available for download at https://doi.org/10.3133/tm1D7.

\section{Checklist for the High frequency Groundwater-Quality Record Approver}

This is a suggested checklist to be used when approving a groundwater-quality record. Feel free to modify these guidelines in consultation with the project manager or section supervisor.

Site Name: Site ID:

Parameter: Year (water/calendar):

Worked by: Date: Analyzed by: Date:

Approved by: Date:

With the project manager and/or the section supervisor, discuss the project's data-quality objectives and set time limits for approving the record. (Recommendations listed below)

Time limits: minutes for checking field sheets, shift tables and spreadsheets minutes for the entire record

Yes|No If field sheets are to be checked, include the following in your analysis:

Probes were calibrated properly.

All appropriate information included.

Any changes in procedure over the course of the year noted and justified

Examine a graph of the raw and corrected data, including marks that coincide with site visits. Use the station analysis as a guide, and look for:

$\square$ Data gaps

Spikes in the data that exceed the project's criteria for deletion

Obvious probe failures

$\square$ Expected patterns in the data (annual, daily, and those due to site specific conditions)

$\square$ Shift implementation - look for the size of shifts by comparing raw and corrected data

Discontinuities (step functions) in the computed data at site visits. If present at a level that exceeds the accuracy of the probe, suggest a solution to eliminate the discontinuity.

Examine other plots of the data provided by the field personnel. If necessary, create additional plots of the data showing comparisons to other constituents at this or nearby sites.

Check for consistency in the data patterns. If inconsistencies are present, suggest an appropriate course of action to remove the inconsistency or explain its presence.

Yes|No If shift tables are to be checked, include the following in your checks:

$\square$ Transcription errors from field sheets to spreadsheets to NWIS-TS.

Calculation errors in spreadsheets.

Missing or inappropriate shifts, if unexplained in spreadsheet or station analysis

Shifts that do not cover the entire range of the data

Approximate percentage of entries checked (circle one): $\begin{array}{lllllllll}20 & 30 & 40 & 50 & 60 & 70 & 80 & 90 & \text { all }\end{array}$ 
The record has been approved! Notify the field personnel if changes are needed to the record.

$\square$ In NWIS-TS, put data into "Approved" status.

$\square$ Update RMS record status as "Approved".

After completing this checklist, put it in the record's folder.

$\square$ Notify the field personnel and the analyzer that the period of record is "Approved"

Approver Comments: 
Publishing support provided by the U.S. Geological Survey Science Publishing Network, Sacramento Publishing Service Center

For more information concerning the research of this report, contact the Director, California Water Science Center U.S. Geological Survey 6000 J Street, Placer Hall Sacramento, California 95819

https://ca.water.usgs.gov 


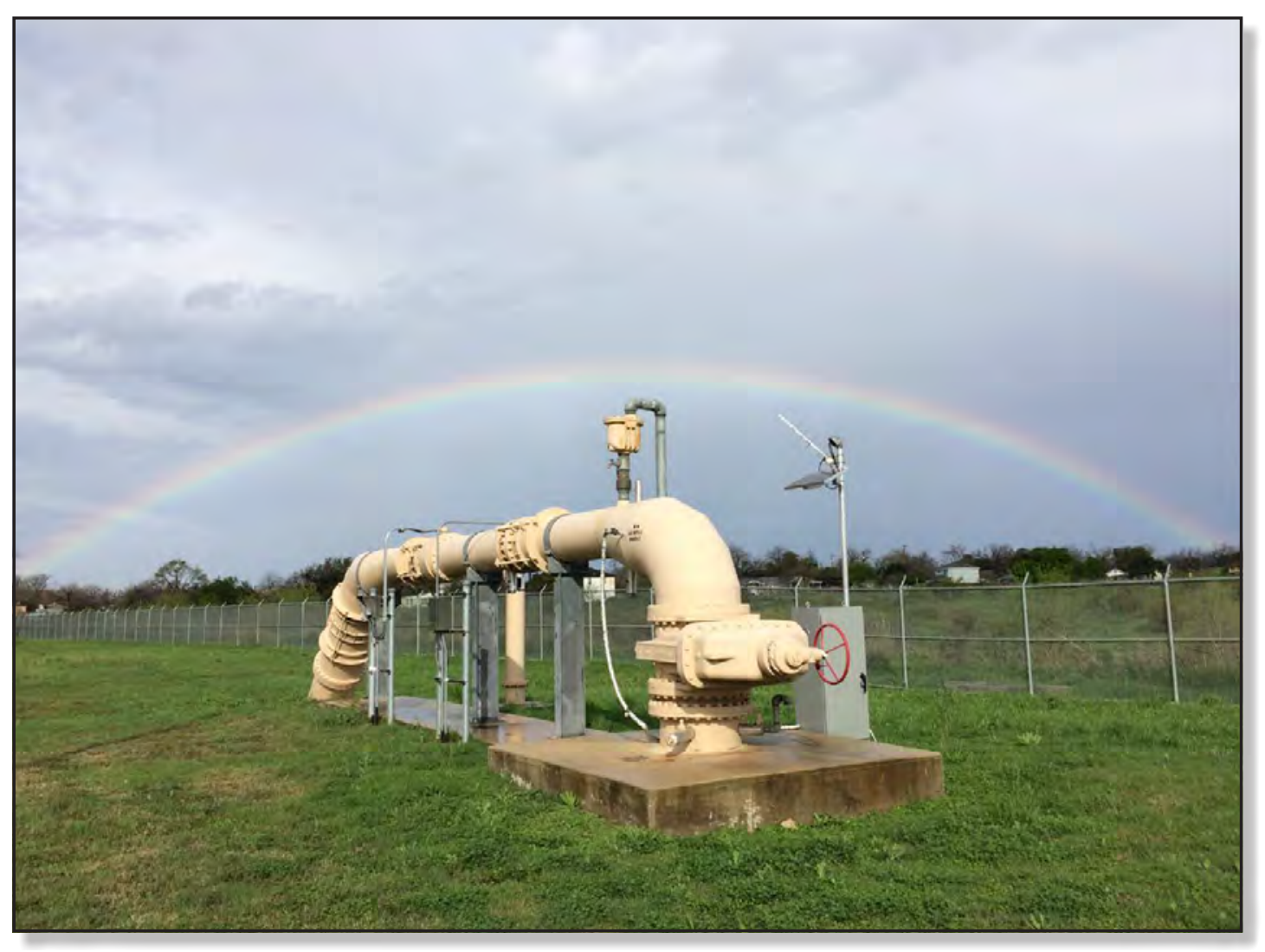

